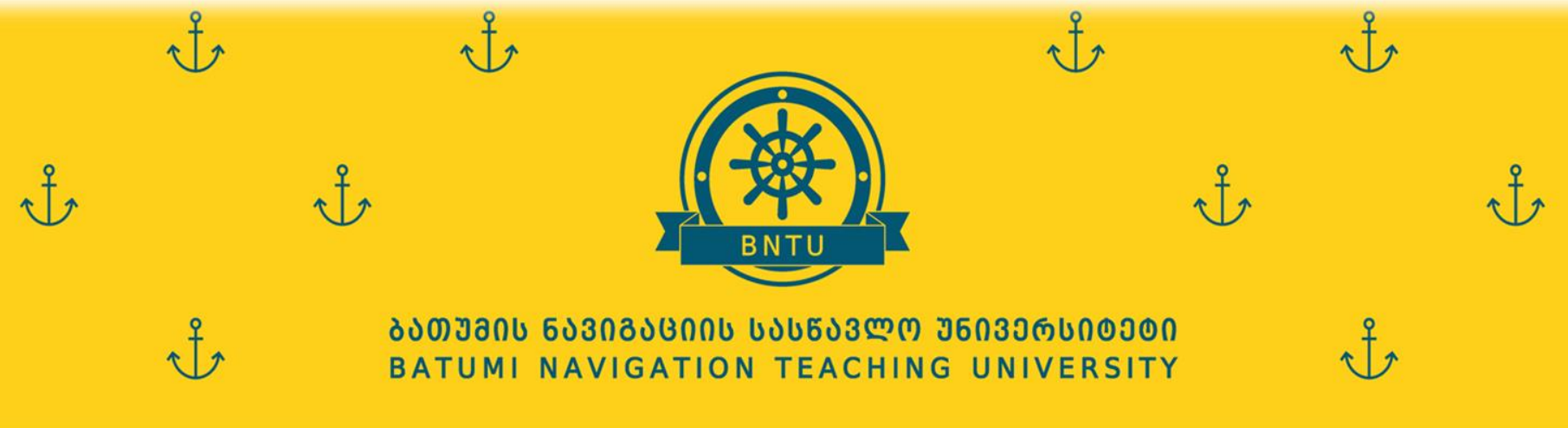

ISTSML 2021

June 24, 2021 I Batumi, Georgia

International Scientific Conference on Sustainable Transport System and Maritime Logistics

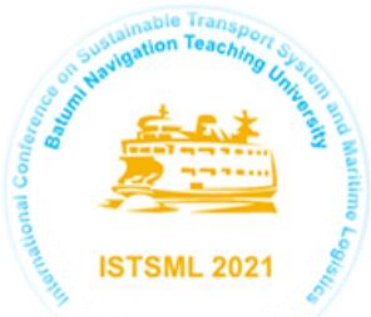

\title{
Proceedings of the International Scientific Conference ISTSML 2021
}

Georgia, Batumi, 24 June, 2021 


\section{CONFERENCE CHAIRMAN:}

PARMEN KHVEDELIDZE Doctor of Transport, Professor, Master Mariner. Rector of Batumi Navigation Teaching University, Georgia

\section{DEPUTY CHAIRMAN:}

BADRI GECHBAIA Head of research center of BNTU, Professor, Georgia

GELA GVARISHVILI Deputy Rector of BNTU Professor, Georgia

KETEVAN GOLETIANI Doctor of Technology, Professor. Dean of the Faculty of Logistics of Batumi Navigation Teaching University, Georgia

\section{ORGANIZING COMMITTEES}

LALI KHVEDELIDZE Chancellor of BNTU, Georgia

NATIA MIKELTADZE Head of Quality Assurance Service at BNTU, Professor, , Georgia

EKATERINE MUSKHAJBA Dean of Maritime-Engeneering Faculty at BNTU, Georgia

VAKHTANG TAVBERIDZE Professor of Batumi Navigation Teaching University, Georgia

TENGIZ APKHAZAVA Doctor of Engineering, Professor of Batumi Navigation Teaching University, Georgia

ELIDA KHVEDELIDZE Associate Professor of Batumi Navigation Teaching University, Georgia

EKATERINE CHIKOVANI Associate Professor of Batumi Navigation Teaching University, Georgia

ZURAB MUSHKUDIANI Associate Professor of Batumi Navigation Teaching University, Georgia

NINO TCHILAIA Assistant Professor of Batumi Navigation Teaching University, Georgia

OMAR LOMIDZE Head of Cathedra of Mechanics at BNTU, Assistant Professor , Georgia

\section{SCIENTIFIC COMMITTEE}

DIDER BENSADON Associate Professor of Dauphine Universite Paris

JUNKO SUGAWARA Associate Professor University of Houston, College of Technology, Supply Chain and Logistics Faculty, Houston

MICHAEL BOURLAKIS Director of Research and Director of the Centre for Logistics, Procurement \& Supply Chain Management Logistics, Procurement and Supply Chain Management. Cranfield School of Management named in Financial Times top ten UK business schools

OLEH NOVOMLYNETS Rector of Chernihiv Polytechnic National University, Professor, Chernihiv, Ukraine MARIANA PETROVA DSc, Professor, St.Cyril and St.Methodius University of Veliko Tarnovo, Bulgaria LUCIA VILCEKOVA Associate Professor of Comenius University in Bratislava, Slovakia

VLADIMIR MESSERLE Pofessor, Vice Chairman of National Scientific Council of the Republic of Kazakhstan EUGENIY TRUSHLIAKOV Professor, Rector of Admiral Makarov National University of Shipbuilding, Ukraine ROMANS DJAKONS Dr.sc.ing., Professor, Academician, President ISMA, Riga, Latvia

DENISS DJAKONS Dr.oec, Professor, Rector ISMA, Riga, Latvia

WOJCIECH SLOMKA Dr n.techn., Dr. h.c. multi, Akademia Kaliska w Kaliszu, Pełnomocnik Rektora, Poland MIROSLAV BADIDA Professor, Doctor of Sciences, Head of Department of Process and Environment Engineering, Technical University of Kosice, Slovak Republic

MIROSLAV KELEMEN Professor, Ing., Rector of University of Security Management in Kosice, Slovak Republic MICHAL VARCHOLA Professor, President of the Academic Society of Michal Baludansky, Slovak Republic OLHA PROKOPENKO Professor of Tallinn University of Technology, Estonia

IGOR KABASHKIN Professor, Dr.Sc., Member of the Professorship Council Transport and Telecommunication institute, Riga, Latvia

HALYNA KUZMENKO Associate Professor of Central Ukrainian National Technical University, Ukraine OLGA RUDENKO Professor at Chernihiv National University of Technology, Ukraine

NATALYA USHENKO Professor of National Aviation University, Ukraine

ETER KHARAISHVILI Professor at Ivane Javakhishvili Tbilisi State University, Honorary Doctor of Batumi Navigation Teaching University, Georgia

ANZOR ABRALAVA Professor at Georgian Technical University, Georgia

PAATA AROSHIDZE Associate Professor of Batumi Shota Rustaveli State University, Georgia

GELA MAMULADZE Professor of Batumi Shota Rustaveli State University, Georgia

GIVI BAKRADZE National Institute of Economic Research, Georgia

NINO PARESASHVILI Associate Professor of Ivane Javakhishvili Tbilisi State University, Georgia

GIVI BEDIANASHVILI Professor of Europian University, Georgia

EVGENI BARATASHVILI Professor of Georgian Technical University, Georgia

NATELA TSIKLASHVILI Vice Rector for Scientific Affairs, Professor of Batumi Shota Rustaveli State University, Georgia 
VLADIMER GLONTI Dean of Faculty Economics and Business, Professor of Batumi Shota Rustaveli State University, Georgia

EKATERINE GVARISHVILI Associate Professor of Batumi Navigation Teaching University, Georgia MANANA MOISTSRAPISHVILI Doctor of Technology, Professor of Georgian Technical University, Georgia ROMAN MAMULADZE Doctor of Technology, Professor of Batumi State Maritime Academy, Georgia ANZOR DEVADZE Professor of Batumi Shota Rustaveli State University, Georgia

The authors are responsible for the content and language of their papers.
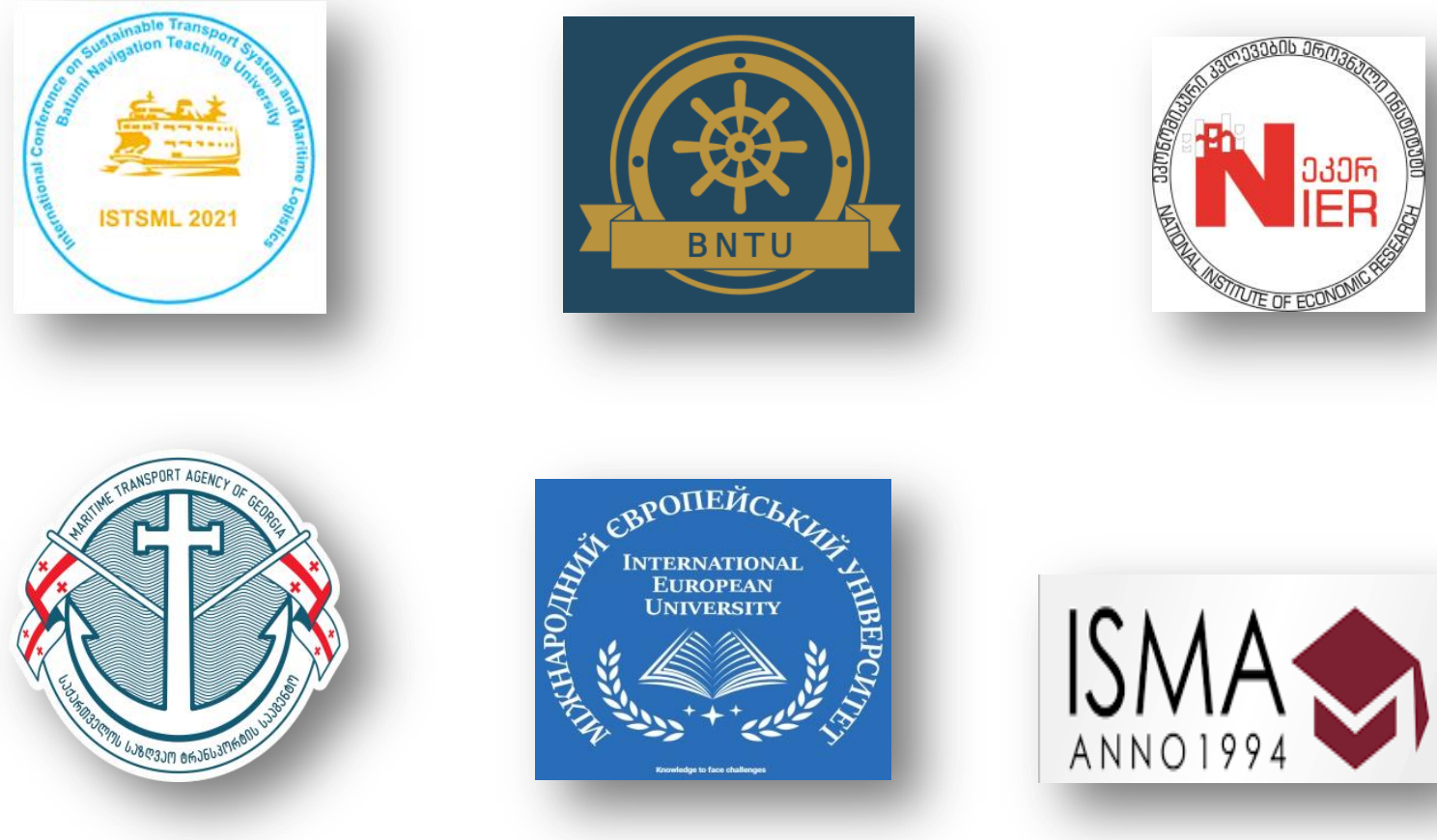

ANNO1994

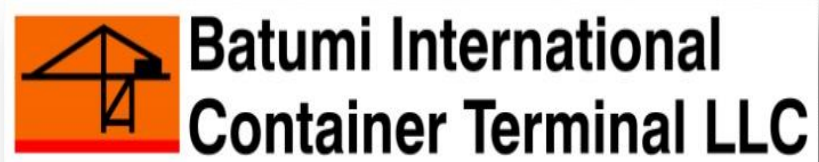

An ICTSI Group Company

ISBN 978-9941-492-40-2

International Conference on Sustainable Transport System and Maritime Logistics. Batumi Navigation Teaching University, June 24, 2021. Publisher: Batumi Navigation Teaching University, Georgia.

DOI: https://doi.org/10.46361/ISTSML-2021

Published under the terms of the Creative Commons

CC BY-NC 4.0 License

(C) Batumi Navigation Teaching University, 2021

(C) Collective authors, 2021 


\section{CONTENTS}

Nishant Rangra

COMMON \& DIFFERENT FACTORS OF CLASSICAL \& MODERN MANAGEMENT

T. V. Diasamidze

8

COMMUNICATION WITHOUT WORDS

D.S. Vlasenko

MANAGEMENTAL INNOVATIONS AS A RESERVE FOR THE DEVELOPMENT OF UKRAINIAN HEALTHCARE INSTITUTIONS

K.G. Goletiani, E. R. Chikovani

ECONOMIC BENEFIT OF THE GEORGIAN TRANSPORT CORRIDOR

E. R. Maghlaperidze

THE IMPACT OF REMOTE WORK INTENSITY ON EMPLOYEE PERCEPTION OUTCOMES

V. Gvetadze, T. Kochadze, K. Lortkipanidze

INCREASING THE EFFICIENCY OF THE COMBUSTION PROCESS BY USING ACTIVE ADDITIVES IN SHIP DIESEL ENGINES

H. Kuzmenko, N.A Shalimova, V. Shalimov

USING DOING BUSINESS RATING FOR ASSESSING THE PRECONDITIONS OF SUSTAINABLE TRANSPORT AND ENVIRONMENTAL ECONOMICS DEVELOPMENT

H.S. Lopushniak, H.I. Kuzmenko, O.I. Kravchuk

SOCIAL RESPONSIBILITY OF BUSINESS IN THE CONDITIONS OF SPREADINGS COVID-19

H.M. Sanikidze

COOPERATIVES IN THE MODERN WORLD

L. Kochlamazashvili, N. Katsitadze, N.Tushishvili

CHANGES IN THE PRACTICE OF CONSUMER BEHAVIOR DUE TO COVID-19 AND OPPORTUNITIES FOR NEW TOURISM COUNTRIES

L. Shymanovska-Dianych, T. Ishcheikin

AN APPROACH TO TRAINING MANAGERS AND ENTREPRENEURS FOR CREATIVE INDUSTRIES

M. Chechelashvili

CONTEMPORARY PROBLEMS OF THE ENTERPRISE MANAGEMENT PROCESS

M. G. Suknishvili

SUSTAINABLE FOOD SECURITY CHALLENGES AND AGRIBUSINESS DEVELOPMENT NEEDS

N.G. Paresashvili, M.P. Tikishvili, N. Kharadze, K.G. Goletiani

STUDY OF RESPONDENT BEHAVIOR IN CONFLICT SITUATION BY CROSS-TABULATION ANALYSIS (SPSS)

N. Tchkhonia

EQUALITY AND TOLERANCE RELIGIOUS DIVERSITY

N. Zhozhuashvili, Ts. Duruli

PANDEMICS AND INVESTMENT CLIMATE OF GEORGIA

O.O. Novomlynets, A.V. Verbytska

INCREASING THE LEVEL OF CORPORATE SOCIAL RESPONSIBILITY IN THE PERIOD OF COVID-19 PANDEMIC

S.V. Ostryanina, I.P. Grebenik

FEATURES OF FORMATION OF TIME MANAGEMENT SYSTEM AT THE ENTERPRISE 
ON NECESSITY OF GEORGIA'S INVOLVEMENT IN THE EUROPEAN TRANSPORT SPACE

N.V. Ushenko, D.O. Semenova, E.Y. Tereshchenko

EMPLOYMENT TRANSFORMATION IN CONDITIONS OF DIGITALIZATION

V.A Riashchenko, O. Lubenchenko

COACHING AS AN INTEGRAL PART OF ON-THE-JOB BUSINESS EDUCATION

Z. Mushkudiani, A. Tsilosani

IMPACT OF COVID 19 ON SMES MANAGEMENT IN GEORGIA

G., lefimova, A., Labartkava, O., Pashchenko

METHODICAL APPROACH TO THE CHOICE OF THE SHIPBUILDING COMPANY RESTRUCTURING VARIANT

L. Hryshyna, N. Hryshyna

69

MANAGEMENT OF THE DEVELOPMENT OF THE MARITIME TRANSPORT POTENTIAL OF UKRAINE

N.B. Mihai

DIGITALIZATION OF THE MARITIME INDUSTRY: ADVANTAGES AND DISADVANTAGES

V. Nekhai, S. Nesterenko, S. Suprunenko, O.Nesterenko, T. Nikitina

ECOLOGICAL MANAGEMENT IN IMPLEMENTATION OF ENVIRONMENTAL GOALS OF THE REGION

I.A. Khmarska

TECHNOLOGIES IN LOGISTICS IN THE CONDITIONS OF WIDE GLOBALIZATION AND DIGITALIZATION

V.I. Glavatskhih

SELECTION OF A BULK VESSEL UNDER THE CONDITIONS OF ITS OPERATION AT DIFFERENT SPEEDS

S. Pechenizka, T. Vysochanska, Y. Bondarenko

PHILOSOPHICAL CONCEPTION OF ECOLOGICAL PROBLEMS IN V. I. VERNADSKY'S NOOSPHERE

I.N. Mayorova, A. A. Temerbek, O.B. Nosovckaj, V. Ryabchuk, E. A. Ocheredco

ENVIRONMENTAL INDICATORS OF A SEAPORT IN AN INCLUSIVE GROWTH STRATEGY

B. Gechbaia, V. Koval

ENTREPRENEURIAL ACTIVITY IN THE CONDITIONS OF IMPLEMENTATION OF THE PUBLICPRIVATE PARTNERSHIP

O. Holovin

THE IMPACT OF EQUIPMENT UPGRADES IN THE REPAIR AND MAINTENANCE OF WATER TRANSPORT ON THE EXAMPLE OF "ILYICHEVSK SHIPREPAIR YARD"

PUBLIC JOINT-STOCK COMPANY

M. Prokopenko,0. Kochubei

TRENDS OF INDUSTRIAL ENTERPRISES DEVELOPMENT IN THE CONTEXT OF DIGITALIZATION 
COMMON \& DIFFERENT FACTORS OF CLASSICAL \& MODERN MANAGEMENT

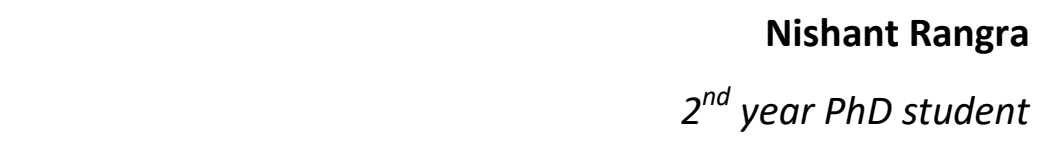

Poltava University of Economics and Trade, Poltava, Ukraine

There is one major common factor between the classical management and modern management that they both are trying to maintain and improve the relations between the employees and the managers. In addition to their differences one can simply point out that classical management is more like dictatorship while modern is more like a democracy.

Modern management theory is the improvement of both the classical and the neo classical approach towards the management. Modern theory has three strong pillars or foundations, which are Quantitative approach, System Approach, and Contingency approach. Quantitative approach, also known as the Operational Research/Operational Analysis, was put forward for consideration by C. W. Churchman in the 1950's. It tells managers to solve the issues that they face through mathematical and statistical formula. For this reason certain formulas have been created to solve problems faced by the managers. Naming few of them Break Even Analysis, Ratio Analysis, Theory of probability, etc. Main advantage of this approach is to solve problems quickly.

Conclusion. From the studies it shows that even though management was present throughout our history but its development did not happen till late. There were many factors that can be pointed out such as business was not really considered or taken as a proper occupation. In the earlier time, well known economists did not considered management subject worthy. Misconception was in the air that "managers are born not made". Only in the last century or so, real study of management as science can be seen.

It can be said or considered that modern management is in the next phase of evolvement with the help of technology. Integration of technology has been able to improve not only communication but also eased to the load work in a company today. Current advancements in management through technology is moving from analog to digital to cloud based today. With the internet easily accessible, many companies especially startups are utilizing cloud network and also availing the modern management applications that are being offered. Companies around the world are also using and analyzing the group's readiness. Even though the companies are still utilizing traditional management with the help of technology, there is an ease of movement towards modern management.

\section{REFERENCES}

1. Richa Shukla. "Modern Management Theory in Principle of Management. URL: http://managementlearningcenter.blogspot.com/2012/09/modern-management-theory-inprinciple.html

2. Chantal Chauvet. Modern management Practices Assessment. URL: https://www.nserc-crsng.gc.ca/nserc-crsng/Reports-Rapports/ModernManagementGestionModerne_eng.asp 
3. Chuck Robert "The Importance of Modern Management Theories in Managing people". URL: https://bizfluent.com/info-8419159-importance-management-theories-managingpeople.html 
COMMUNICATION WITHOUT WORDS

\author{
Diasamidze T. V., \\ Assistant-professor \\ Batumi Navigation Teaching University \\ Batumi, Georgia
}

Communication is a natural, universal phenomenon whose complexity generates a variety of forms of expression, involving different meanings, specific codes, diverse channels and ways of producing. All these because human communication in general, teaching communication in particular manifest themselves as multi-determined phenomena being simultaneously: information, action, interaction, relationship, transaction and require a minimum of innate skills, acquired through training. The modern communicational space represents a rather complex system, whose one of the most important elements is different types of communication. A person acts differently depending on the situation, and interacts with different people in various ways. Every person represents a specific culture, and is different from the representatives of other cultures. Communication is complete only when information sent is interpreted by the listener as was implied by the sender. Nonverbal indicators play vital role in interpersonal communication; during interpersonal communication, $90 \%$ of the information is shown by the nonverbal communication (voice, face expression, body language), and $10 \%$ average is transmitted through verbal communication (Adelman and Levine 1993:45).

There are several principles of nonverbal communication:

- Despite the wish of the speaker, nonverbal communication is constantly transmitted, even when the verbal communication is finished; in other words, when the speaker stops sending the information; body language, the way person is dressed, face expression, is incomplete list of nonverbal signs that constantly send the information about emotions, mood, and attitude of the speaker;

- During the process of interaction with someone we have to be familiar with body language in order to:

- $\quad$ read nonverbal communication of a person we communicate with (sign language, facial expression, timbre of voice, height, speed , etc.).

- $\quad$ Pay attention to our body language which is controlled subconsciously and organize it and consciously control it.

- Control of the body language is very important during presentations (Viechek 1999:34).

People use nonverbal gestures in order to clearly show their ideas, feelings, and emotions. It is common for all cultures, but for some cultures the gestures could differ and mean something else. Therefore for a successful communication between representatives of different cultures is important to know and understand the nonverbal forms that are common for the specific culture. 
When hearing the conversation, words transmit lots of information, but it also can be used to understand how cultured the speaker is. At the same time, his facial expression, gestures, and intonation give us the information about his character. The most important feature of the nonverbal communication is that it is created by all the organs of the sense: sight, hearing, sense, taste, smell which are creating their own way of communication. Elements of nonverbal communication are: kinesis, tactile behavior, sensorics, proxemics, chronemics.

Facial expression, gestures, body language show the inner nature of a person. Moving, reactions (going pale or blushing) also show the character. And the addressee who is interested to evaluate adequately the speaker must be aware of those signs.

Nonverbal communication is considered to be more reliable and sincere, because it is harder to control the nonverbal elements of the communication than the words. In case when those two contradict each other, listeners tend to rely on nonverbal elements of the communication. Therefore, we again encounter a situation which proves that during conversation people tend to rely on nonverbal elements, because it is easy to "play" with words, but control of the nonverbal part is basically impossible.

In conclusion: During the process of interaction with someone we have to be familiar with body language in order to: read nonverbal communication of a person we communicate with (sign language, facial expression, timbre of voice, height, speed, etc.

\section{REFERENCES}

1. Adelman, Mara B and Levine Deena R. "Beyond Language: Cross-Cultural Communication". 1993. New Jersey: Prentice Hall Regents. P -45.

2. Гойхман О.Я. Надейни Г.М. Речевая коммуникация. 2005: Москва. Р-6-7.

3. Wiechecki, Barbara. Non-Verbal Communication: Classroom Activities For Raising Cross-Cultural Awareness. 1999N.Y p-34. 


\title{
MANAGEMENTAL INNOVATIONS AS A RESERVE FOR THE DEVELOPMENT OF UKRAINIAN HEALTHCARE INSTITUTIONS
}

\author{
Vlasenko D.S., \\ student of MEN-41 group, \\ Bondar-Pidhurska O.V., DS, Associate Professor Department of Management \\ Poltava University of Economics and Trade \\ Poltava, Ukraine
}

The external environment is constantly changing, new threats are emerging that increase competition, require the development and marketing of new innovation results. In these circumstances, health care facilities need to be reformed and additional sources of development sought. Thus, there is a need to develop, search for and implement innovations for this industry.

The term "innovation" was used by J. Schumpeter in the 30 s of the twentieth century, where innovation meant changes to introduce and use new types of consumer goods, new production, vehicles, markets and forms of organization in industry [1, p. 208]. The innovation involved inventing new and improved ways to do so by modifying existing processes and / or creating more efficient procedures, ideas and products [2, 3]. Moreover, managerial innovations involve certain changes in the system of organization and management of enterprises in order to improve it and increase efficiency.

Conclusion. Finding additional reserves for the development of health care facilities in Ukraine is an extremely important and challenging task today, where managerial innovation should fulfill this mission, revealing new methods and forms of planning, work organization and operational processes. Thus, the application of managerial innovations in the activities of health care institutions of Ukraine is a promising means of obtaining long-term and significant competitive advantages, as well as a new way of organizing operational processes, which should provide additional funds for further development.

\section{REFERENCES}

1. Балабанов И.Т. Инновационный менеджмент. СПб.: Питер, 2000. 208 с.

2. Kashyap Vyas. Innovation and Its Importance within Business Organizations. URL: https://interestingengineering.com/innovation-and-its-importance-within-business-organizations.

3. Бондар О. В. Інноваційна політика України в контексті сталого розвитку та євроінтеграції. Інноваційна економіка. 2011. № 6 (25). С. 13-16. 


\title{
ECONOMIC BENEFIT OF THE GEORGIAN TRANSPORT CORRIDOR
}

\author{
Goletiani K.G., \\ PhD, Professor, \\ Batumi Navigation Teaching University \\ Batumi, Georgia \\ Chikovani E. R., \\ PhD, Associated Professor, \\ Batumi Navigation Teaching University \\ Batumi, Georgia
}

Georgia has long been a crossroads connecting East and West, North and South, through which the "Silk Road" connecting Europe and Asia passed. Due to its favorable geographical location, it still retains the function of international transport crossroads. However, it does not mean that we have already received the benefits and that's all fine, we need to use this road effectively and provide management.

Today, there are important corridors that are in serious competition, such as the TransSiberian Highway, the sea corridor from Chinese ports to Europe, the northern direction of the Trans-Asian Railway, the southern Turkish-Iranian corridor to India, and more. In such highly competitive conditions, in order for the Silk Road to be competitive, it is necessary to think about how to improve the quality of the corridor, the main components of which are: further development of transport infrastructure, increasing the speed of cargo movement in the corridor, price optimization and safety. Ultimately, all this will promote development of the country's domestic business, export of goods and services to the global market, employment of citizens and raising of their standards of living.

In examination of competitiveness improving problems of Silk Road, the following issues, such as Georgia's geopolitical and geoeconomic factors and their importance, cargo carriage through the Transcaucasian transport corridor, condition and prospects of transportation in Georgian transport sectors: road, air and railway, as well as creation of logistics centers and port clusters should be considered.

Current picture on all these aspects shows that although the dynamics of cargo volume has increased in Georgia in recent years, competitiveness is still declining due to the reduction of cargo flow from Asia, as well as high rates of rail transportation, while the corridor through Russia and Iran is positioned with a much more flexible tariff policy; Also, we don't have deep-water ports and competing transit corridors are activated, and in the light of all this, specific measures need to be taken that are delayed, but one way or another is still in the process of implementation. Modernization of Georgian ports and Azerbaijan-Georgia railway is in the process, as well as we are at the stage of looking for potential investors for the construction of 
Anaklia deep-water port, which will be one of the important units among strategic projects: It will be the transport hub and the warehouses will serve ships with a capacity of 10,000 containers that until now was almost impossible.

Georgia's unified transport system is crucial for unhindered movement of goods in the transit corridor to effectively use both the country and the geo-economic function.

It should be noted that there is a lack of practical application of theoretical heritage accumulated in the Georgian economic literature. In fact, Georgia has found its place in the field of geopolitical and geoeconomic interests after departure from the Soviet Union and achieving independence.

Georgia is a maritime country. It has access to the Black Sea, which is a great advantage over countries that do not have such access. As for land communications, it is a well-known fact that due to its favorable location, Georgia has long had a trade route from Europe to India. Our country has the potential and capabilities to connect the industrial West and the raw material producing East, as well as to perform an active transit function between North and South. Georgian air communications are also very important. We have a very attractive location in this regard as well. We are in the middle of the US-Japan route, at about the same latitude as New York and Tokyo, which significantly increases the competitiveness of this location. Nevertheless, the competitiveness of the Georgian transport corridor in relation to other corridors is reduced, in particular: the main freight traffic is reduced, at the same time in most cases road transport with other adjacent countries provides two-way cargo transportation and slightly participates in transportation through corridor; Rail shipments are also low: more than $92 \%$ of cargo accounts for Azerbaijan and Armenia, and as mentioned above, the share of cargo in Asian countries is very small and has been declining in recent years, one of the main reasons of which is the more flexible tariff policy of corridor through Russia and Iran.

Given the current reality, it is important not only to study the technical and organizational problems of the establishment and operation of the optimal transport system serving the transit corridor, but also to find ways to increase the competitiveness of the whole corridor in relation to Georgia, about which we have very scarce literature. Therefore, it is necessary to study the activities of all connecting links of the supply chain, railway, port, air and road infrastructure and logistics centers on the territory of Georgia, in order to show more clearly their opportunities and prospects for further development, which will significantly promote to business development, employment of citizens and improvement of their economic and social conditions.

\section{REFERENCES}

1. Chikovani E., Main directions of freight transportation improvement in Georgia. Tbilisi, 2020;

2. Tsanava N., Papiashvili M. Georgia Transport Corridor and its economic efficiency. Tbilisi, 2019; 
3. Roadmap for Georgia's EU Integration, More Integration for New Opportunities, Ministry of Foreign Affairs of Georgia, 25.02.2019;

4. Government of Georgia, basic data and directions of the country for 2021-2024 (revised version), Tbilisi, 2020

\section{THE IMPACT OF REMOTE WORK INTENSITY ON EMPLOYEE PERCEPTION OUTCOMES}

Maghlaperidze E. R.

PhD Student

Ivane Javakhishvili Tbilisi State University

Tbilisi, Georgia

Relevance of the Research. Remote work, also known as telecommuting, is quite popular across the globe, however, it became especially relevant during the Covid-19 pandemic lockdown, when the vast majority of companies were forced to switch employees to remote work mode. Labor market trends, job specifics and the labor needs are changing under the influence of the modern digital world, and as never before, remote work became the most relevant form of employment contract. The main factor of employee motivation is not only a salary any more, but emotional well-being, flexible work schedule and an autonomy are no less important to them today. Therefore, we find it interesting to examine the consequences of remote working and employee attitudes towards it.

Aim and Objectives of the Research. The aim of the research is to study the peculiarities of remote work in the insurance sector of Georgia and to find the ways of its improvement. Based on the aim of our research, the following objectives were formulated:

Identify the link between remote work intensity and the employee views about advantages and disadvantages of remote work;

$>\quad$ Determine a link between remote work intensity and employee job satisfaction;

$>\quad$ Determine a link between remote work intensity and Work-Family Balance;

$>\quad$ Assess the impact of remote work intensity on employee perceived career advancement opportunities;

Research Object and Methods. The object of our research is insurance companies operating in Georgia. Using the anonymous survey method 528 employees of the mentioned organizations participated in the study. The sample size of 528 people has ensured the representativeness of the survey results. Research was conducted using a questionnaire survey method, it was carried out remotely via emails using Google Forms. The questionnaire included 42 questions and 208 answer options. Various statistical procedures and methods (statistical software package) were used in the processing of the questionnaire and data analysis, including: descriptive statistics, cross-tabulation analysis, filtering, Frequency distribution, Chi-square tests. 
Theoretical Basis of the Research. Although the research on remote work topic began as early as the 1970s, it has only gained real recognition since the 2000s. The term "telecommuting" was first coined by Jack Nilles (1975) in the 1970s, when he was working remotely as an engineer on NASA's communications systems and referred to his work as telecommuting. He defined telecommuting as the way of working outside of a standard workplace through telecommunications and computer-based technology (Nilles, 1994). Although different scientists interpret remote work differently, main idea is the same for all of these definitions - working away from a central workplace with the help of modern technology.

Remote work presents many advantages and disadvantages for both the organizations and the employees. The most important advantage of telecommuting is that it allows the employee to do business and perform activities from the desired location. Besides this, remote worker enjoys the advantage of a flexible work schedule, autonomy and cost savings. The most important disadvantage of remote work is the lack of direct social contacts which leads to social isolation and the difficulty of separating working and non-working hours (work and home lives). It is noteworthy that the remote work mode allows the employer to use the available resources more efficiently, they can reduce organization's overhead/facility costs, also the investments and expenditures in office building. Offering telecommuting work arrangement reduces employee turnover, provides organizations with a larger talent pool and increases employee productivity, which in turn is in the best interest of the company.

\section{The hypotheses of the study}

1. Remote Work Intensity affects the respondents' opinions about the biggest disadvantages of working remotely

2. Remote Work Intensity affects the respondents' opinions about the biggest advantages of working remotely

3. Remote Work Intensity has an important influence on employee job satisfaction

4. Keeping a balance between work and personal life depends a lot on the intensity of remote wok

5. Opinions about reducing the chances of career advancement opportunities differ among the groups of respondents according to the intensity of remote work.

\section{Conclusions}

$>\quad$ More than $60 \%$ of the employees work fully remotely and up to $30 \%$ on part-time basis, which is clearly derived from the pandemic reality - the greatest challenge to the entire world. Regarding the intensity of remote work, $48.3 \%$ of the employees state that they prefer to work remotely less often. Considering that most of the respondents work fully remotely, it is obvious that they are not very satisfied with this working style and prefer to work relatively less from home.

People who work remotely for 3 or 4 days a week are most satisfied with their job $(88 \%$ / 81\%), while the most dissatisfied are the ones who work remotely 5 days a week (15.9\%). 
There is a maximum statistical correlation between these two variables: intensity of remote work and the job satisfaction, at the level of 0.001 (statistical significance level $P<0.001$ ).

For the full-time ( 5 days) remote workers, the biggest disadvantage of remote work is the difficulty of keeping work and home lives separate (29.1\%), followed by overwork stress and fatigue $26.1 \%$, and for the part-time workers the reduction of relations with colleagues - social isolation (35\%). There is a maximum statistical correlation between these two variables at the level of 0.001 (statistical significance level $P<0.001$ ).

The biggest advantage for full-time remote workers is the ability to work from anywhere $(24.3 \%)$, followed by the time savings $-22.8 \%$ and cost reduction $-22.6 \%$ of commuting. For part-time remote workers, a flexible work schedule (44.5\%), as well as commuting time saving (24.1\%) and a better work-life balance $(12.4 \%)$ are preferred. There is a maximum statistical correlation between these two variables at the level of 0.001 (statistical significance level $P$ $<0.001)$.

The majority of part-time remote workers are better able to maintain a balance between work and personal life while working remotely $(70.8 \%)$ and the full-time remote workers mostly (64.1\%) reject this statement. There is a maximum statistical correlation between these two variables at the level of 0.001 (statistical significance level $P<0.001$ ). The result we got, tells us that the full-time remote workers are experiencing the blurring of boundary between paid work and personal life, and facing work-family conflict and a professional isolation.

$>\quad$ The majority of full-time remote workers - 68.5\% - think that their chances of career advancement while working remotely are reduced since their manager rarely sees them, while the part-time employees think the opposite. There is a maximum statistical correlation between these two variables at the level of 0.001 (statistical significance level $P<0.001$ ). The explanation for these results lies in the fact that part-time remote workers do not feel professionally isolated, they go to the office once a week (at least) and meet with a supervisor, so they do not feel that working remotely may reduce their chances of career advancement.

\section{REFERENCES}

1. Belanger, F., \& Collins, R. W. (1998). Distributed work arrangements: A research framework. Information Society(14), 137-152. doi:https://doi.org/10.1080/019722498128935

2. Buffer and AngelList. (2020). The 2020 State of Remote Work. Retrieved February 22, 2021, from https://Ip.buffer.com/state-of-remote-work-2020

3. Cooper, C. D., \& Kurland, N. B. (2002). Telecommuting, professional isolation and employee development in public and private organizations. Journal of Organizational Behavior, 23, 511-532. doi:https://doi.org/10.1002/job.145

4. Dubrin, A. J. (1991). Comparison of the job satisfaction and productivity of telecommuters versus in-house employees: A research note on work in progress. Psychological Reports, 68, 1223-1234. doi:https://doi.org/10.2466\%2Fpr0.1991.68.3c.1223 
5. Gajendran, R. S., \& Harrison, D. A. (2007). The good, the bad, and the unknown about telecommuting: Meta-analysis of psychological mediators and individual consequences. Journal of Applied Psychology(92), 1524-1541. doi:https://doi.org/10.1037/0021-9010.92.6.1524

6. Giorgobiani, M., Paresashvili, N., \& Dugladze, D. (2021). The Importance of Defining Competencies in the Staff Selection Process. Innovative Economics and Management, 8(1), 37-45.

7. Global Workplace Analytics. (2020, March 13). Latest Work-AtHome/Telecommuting/Mobile Work/Remote Work Statistics. Retrieved February 20, 2021, from https://globalworkplaceanalytics.com/telecommuting-statistics

8. Golden, T. D., \& Veiga, J. F. (2005). The impact of extent of telecommuting on job satisfaction: Resolving inconsistent findings. Journal of Management, 31, 301-318. doi:https://doi.org/10.1177/0149206304271768

9. Guimaraes, T., \& Dallow, P. (1999). Empirically testing the benefits, problems, and success factors for telecommuting programmes. European Journal of Information Systems(8), 4054. doi:https://doi.org/10.1057/palgrave.ejis.3000317

10. Hamilton, E. (2002). Bringing work home: Advantages and challenges of telecommuting. Boston: The center for Work \& Family, Boston College, Carrol School of Management. Retrieved February 20, 2021, from file://C:/Users/admin/Downloads/Bringing\%20Work\%20Home_Telecommuting.pdf

11. Hossen, M. M., Begum, M., \& Zhixia, C. (2018). Present Status of Organizational Work-Life Balance Practices in Bangladesh: Employees Expectation and Organizational Arrangements. Journal of Eastern European and Central Asian Research (JEECAR), 5(1). doi:https://doi.org/10.15549/jeecar.v5i1.199

12. Kharadze, N., \& Gulua, E. (2018). Personal Development Peculiarities on Gender Perspective in Georgia. European Journal of Multidisciplinary Studies, 3(3), 111-123.

13. Kharadze, N., Paichadze, N., \& Paresashvli, N. (2019). General Trends of Business Career Management. European Journal of Economics and Business Studies, 153-177. doi:http://dx.doi.org/10.26417/ejes.v5i1.p153-177

14. Locke, E. A. (1976). The nature and causes of job satisfaction. In M. D. Dunnette (Ed.), Handbook of industrial and organizational psychology. Chicago: Rand McNally.

15. Maghlaperidze, E. (2021). Preferred Work Arrangements and Career Advancement Opportunities in Remote Working Conditions - Analysis in Demographic Terms. Innovative Economics and Management, 8(1), 16-27.

16. Nickson, D., \& Siddons, S. (2011). Remote Working Linking people and organizations. New York: Routledge Taylor \& Francis Group.

17. Nilles, J. M. (1975). Telecommunications and organizational decentralization. IEEE Transactions On Communications(Commun.23), 1142-1147.

18. Nilles, J. M. (1994). Making telecommuting happen: a guide for telemanagers and telecommuters. New York: Van Nostrand Reinhold. 
19. Owl Labs, Global Workplace Analytics. (2019, September). State of Remote Work. Retrieved February 20, 2021, from https://www.owllabs.com/state-of-remote-work/2019

20. Pinsonneault, A., \& Boisvert, M. (2001). The impacts of telecommuting on organizations and individuals: A review of the literature. Telecommuting and virtual offices: Issues and opportunities, 163-185. doi:10.4018/978-1-878289-79-7.CH010

21. Poór, J., Kovács, I. É., Mázásné, H. D., Mack, Á., \& Fehér, J. (2018). Flexibility benefits - Cafeteria Plan. How the characteristics of the firms affect the system Cafeteria Plan in Hungary. Journal of Eastern European and Central Asian Research (JEECAR), 5(1), 20. doi:https://doi.org/10.15549/jeecar.v5i1.190

22. PwC United States. (2020, June 25). US Remote Work Survey. Retrieved February 22, 2021, from pwc.com: https://www.pwc.com/us/en/library/covid-19/assets/pwc-return-to-worksurvey.pdf

23. Virick, M., daSilva, N., \& Arrington, K. (2010). Moderators of the curvilinear relation between extent of telecommuting and job and life satisfaction: The role of performance outcome orientation and worker type. Human Relations, 63(1), 137-154. doi:https://doi.org/10.1177/0018726709349198

\title{
INCREASING THE EFFICIENCY OF THE COMBUSTION PROCESS BY USING ACTIVE ADDITIVES IN SHIP DIESEL ENGINES
}

\author{
Gvetadze V., \\ PhD, Associate Professor, \\ Kochadze T., \\ PhD, Professor, \\ Lortkipanidze K. \\ Doctoral candidate
} Akaki Tsereteli State University, Kutaisi, Georgia

As is known, idle and heating modes are characterized by unfavorable combustion conditions of the fuel mixture, which leads to incomplete combustion of the mixture and the increase in percentage of $\mathrm{CO}, \mathrm{CH}$ and $\mathrm{CO}_{2}$ in working gases. Therefore, in order to ensure the complete combustion, we can use an "active" additive, particularly hydrogen, the addition of which at a certain dose significantly improves the combustion process due to the emergence of the additional active centers as a result of its physico-chemical properties, and transfers the work of engine into the zone of the stoichiometric and poor mixture, as a result of which the combustion process is becoming more sophisticated, percentages of $\mathrm{CO}, \mathrm{CH}, \mathrm{CO}_{2}$ are reduced, and besides, the fuel cost indicator and the engine start property are improved. 
From an environmental perspective, hydrogen is an ideal fuel. It burns in net oxygen resulting in water separation. There is no pure hydrogen in nature. It can be obtained in two ways: 1. from liquid or gaseous hydrocarbons, in which percentage of hydrogen is $\approx 15 \%$; 2 . from water by way of electrolysis. The resource of the latter is colossal and renewable, although the electrolysis process is much more expensive and is highly energy intensive. Therefore, hydrogen is obtained from water in small quantities; Hydrogen is mainly obtained from hydrocarbons, in which percentage of carbon is up to $85 \%$, the combustion of which emits a major portion of the amount of heat. The main advantages of hydrogen are as follows: good environmental characteristics, high energy performance, unique kinetic characteristics, high burning rate and low ignition energy [1].

Based on the properties of hydrogen, it can be used as an additive to traditional fuel, and also it possible to convert the engines directly hydrogen. To use hydrogen as fuel in gasoline and diesel engines, it is necessary to make changes to the design of the fuel supply system. During the carburetion, fueling is deteriorating and the power drops due to the low density of hydrogen. During fuel injection, the size of the charge can be increased or maintained at the level of existing diesel fuel. It could therefore be concluded that it is more beneficial to use hydrogen in diesel engines. For self-ignition of a mixture of hydrogen and air in a cylinder, it is necessary to raise the temperature at the end of the compression, which is possible by injection or heating the charge on fueling.

Given that in the case of using hydrogen as a number-one fuel, the power reduction and the detonation combustion at high load modes take place, it would therefore be better to use hydrogen in the composition with the main fuel. It is therefore advisable for the engine to run in idle and heating modes with a high hydrogen content in the fuel. Adding hydrogen to a traditional fuel allows us to take a completely new look at the work process in a cylinder. A positive solution to this issue will increase both the fuel efficiency of engine and reduce flue gas toxicity. However, in solving the problem, it is necessary to create a combination of hydrogen and gasoline, which ensures the normal conduct of the combustion process in each specific mode.

Based on the experimental data, the research team has developed a methodology that will allow us to determine the ratio of hydrogen and gasoline in the mixture in each case, which ensures a high level of workflow. In this case, in particular, we can determine the minimum amount of gasoline that ensures the smooth running of the process despite leaning of the mixture. The methodology is based on the determination of the amount of heat energy released during the combustion process, which in this particular case is calculated by the formula:

$$
\mathrm{Q}=\beta \cdot G_{\mathrm{g} 0} \cdot H_{\mathrm{ug}}=G_{\mathrm{ga}} \cdot H_{\mathrm{ug}}+G_{\mathrm{h}} \cdot H_{\mathrm{uh}},
$$

where $G_{\mathrm{g} 0}$ - gasoline consumption without the addition of hydrogen; $G_{\mathrm{h}}$ - consumption of hydrogen as an additive; $G_{\text {ga }}$ - gasoline consumption after the addition of hydrogen; $H_{\text {ug }}$ and $H_{\text {uh }}$ the lowest heat value of the hydrogen and gasoline burning; $\beta$ - gasoline reduction coefficient in case of the addition of hydrogen, which determined by the expression

$$
\beta=G_{\mathrm{g} 0} \cdot H_{\mathrm{ug}}+G_{\mathrm{h}} \cdot H_{\mathrm{uh}} G_{\mathrm{g} 0} \cdot H_{\mathrm{ug}}=G_{\mathrm{g} 0}+\mathrm{K} \cdot G_{\mathrm{h}} G_{\mathrm{g}},
$$

where $K=H_{\text {uh }} / H_{\text {ug }}=2,73$ 
The analysis of the expression shows that $\beta$ is a dimension-less coefficient, and values included therein can be determined experimentally, when $G_{h}=0$ and $\beta=1$. Figure 1 illustrates is variation of the coefficient $\beta$ depending on the excess air coefficient $(\alpha)$

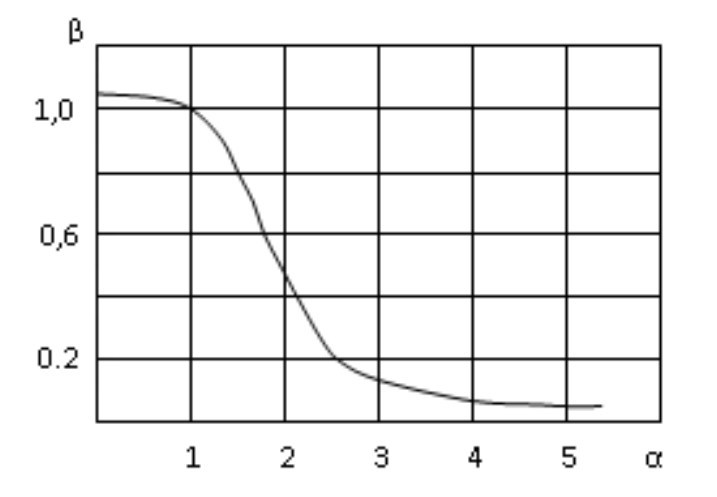

Fig. 1. The dependence of the dimensionless coefficient $\beta$ on the excess air ratio $\alpha$

When calculating the coefficient $\beta$, there was used $1.5 \mathrm{I}$ of working volume and the regulatory characteristics of the gasoline-powered engine with compression ratio of 9,9, which have been determined in the case of the constant power and the optimal ignition advance angle.

The analysis of the graph shows the static relationships between the coefficients $\alpha$ and $\beta$, without dependence on the consumption of gasoline hydrogen, from which it is clear that the increase in $\alpha$, or leaning of the mixture results in the reduction of the coefficient $\beta$, indicating the increase in the percentage of hydrogen in the mixture.

As is seen in the expression of $\beta$, it includes two unknown values $G_{\mathrm{g}}$ and $G$ h that prevents their determination. That means that there is required one more relationship between these two values. This value is the known dimension-less relationship

$$
\psi=G_{\mathrm{h}} / G_{\mathrm{h}}+G_{\mathrm{g}}
$$

Which determines the lower limit of normal burning of the gasoline-hydrogen mixtures. The dependence of the coefficient $\psi$ on the excess air ratio $(\alpha)$ is shown in Figure 2.

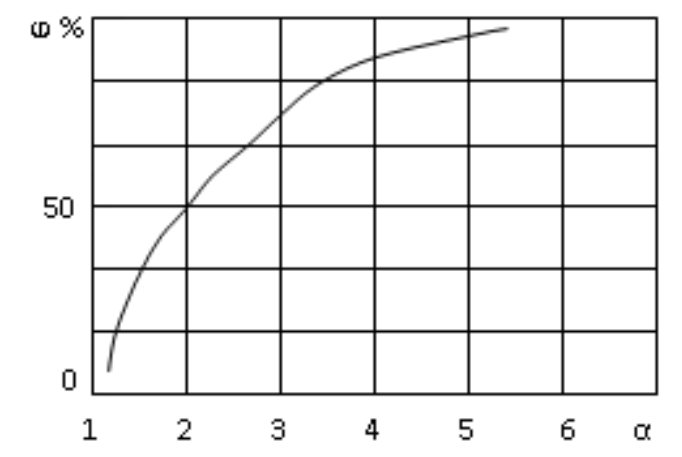

Fig.2. The dependence of the dimensionless parameter $\psi$ on the excess air ratio $\alpha$

Thus, based on the derived expression, it is possible to determine theoretically that ratio of gasoline and hydrogen in the mixture, which ensures the development of the process of burning in the engine's cylinder in any operating mode of engine. The paper [2] presents the results of the 
engine static test experiments, which showed that the use of hydrogen as an additive in idle and heating modes allowed us to reduce $\mathrm{CH}$ by $30 \%$, $\mathrm{CO}$ - by $35 \%$, while percentages of $\mathrm{NO}_{x}$ and $\mathrm{CO}_{2}$ remained unchanged. Table 1 presents the toxicity test results

Table 1

\begin{tabular}{|l|c|c|c|c|}
\hline & $\mathrm{CHg} / \mathrm{km}$ & $\mathrm{CO} g / \mathrm{km}$ & $\mathrm{NO} \mathrm{g} / \mathrm{km}$ & $\mathrm{CO}_{2} \mathrm{~g} / \mathrm{km}$ \\
\hline $\begin{array}{l}\text { The engine with a regular system } \\
\text { without a hydrogen additive }\end{array}$ & 0,37 & 2.62 & 0,10 & 167,5 \\
\hline $\begin{array}{l}\text { The engine with a hydrogen additive } \\
\text { system }\end{array}$ & 0,25 & 1,57 & 0,11 & 167,5 \\
\hline
\end{tabular}

The engine static test results have been checked and verified during the dynamic test, which demonstrates the effective use of hydrogen as an additive, ensures sustained engine operation, and expands the stable operating limits. The effective use of hydrogen as a fuel or an additive is also proven in the paper [3], which states that it is better for the engine to run at idle and partial-load modes with a high hydrogen content in the fuel mixture.

As the load increases, the hydrogen content in the fuel should decrease and the supply of hydrogen at full load mode should be stopped. This will allow us to maintain the power characteristics at the existing level.

Figure 3 illustrates the economical and toxic characteristics depending on the change in hydrogen concentration in the fuel mixture. $E=8.2 ; \mathrm{V}=2.45 \mathrm{I} ; \mathrm{N}_{\mathrm{e}}=6.2 \mathrm{~kW} ; \mathrm{n}=2400 \mathrm{rpm}$.

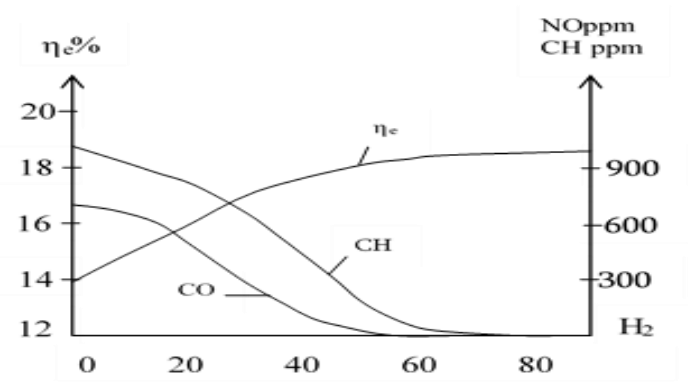

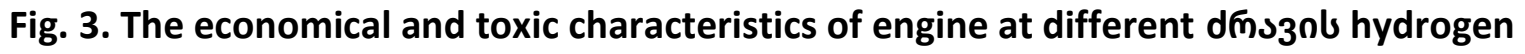
concentrations in the fuel mixture

The use of hydrogen as a fuel or an additive to the main fuel allows us to substantially expand the effective lean-burn limits of the fuel mixture, enabling us to the efficiency and reduce toxicity. As can be seen from the graph, the increased concentration of hydrogen in the fuel mixture increases the engine efficiency and its maximum value when operating on hydrogen $(100 \%)$ reaches $18.5 \%$, which is 1.35 times higher then it was in operation of engine on gasoline, where the efficiency rate is $14 \%$ (Fig. 3). However, the composition of the mixture corresponding to the maximum efficiency rate is shifting towards the lean mixture. The effective impurity limit of the mixture when running on gasoline is $\alpha=1,1$, while when running on hydrogen, $\alpha=2,5$. An increase in hydrogen concentration in the mixture leads to reductions in hydrocarbon $(\mathrm{CH})$ in the exhaust, in some modes, when running on hydrogen, it is reduced to zero ( $\mathrm{H} 2 \geq 70 \%$ ). The amount of hydrocarbons depends to a large extent on the intensity of the combustion process. Emissions 
of nitric oxide (NO) are determined by temperature conditions of combustion of the mixture. When the engine is running on hydrogen, working on the poor composition of the mixture allows us to reduce the maximum combustion temperature $\left(T_{\max }\right)$. This in turn reduces percentage of nitric oxide (NO) [3]. In some modes it is reduced to zero, in particular when $\mathrm{H}_{2} \geq 50 \%$ which affects the incomplete combustion of the mixture. Near the cold walls of the chamber, the flame is extinguished, and such zones contribute to the release of $\mathrm{CH}$. The second source of $\mathrm{CH}$ generation is oil that gets into the cylinder due to incomplete removal of oil from the walls, as well as due to oil leakage in the gaps between the valve stem and the guide block. An increase in hydrogen concentration in the mixture causes the reduction of $\mathrm{CH}$.

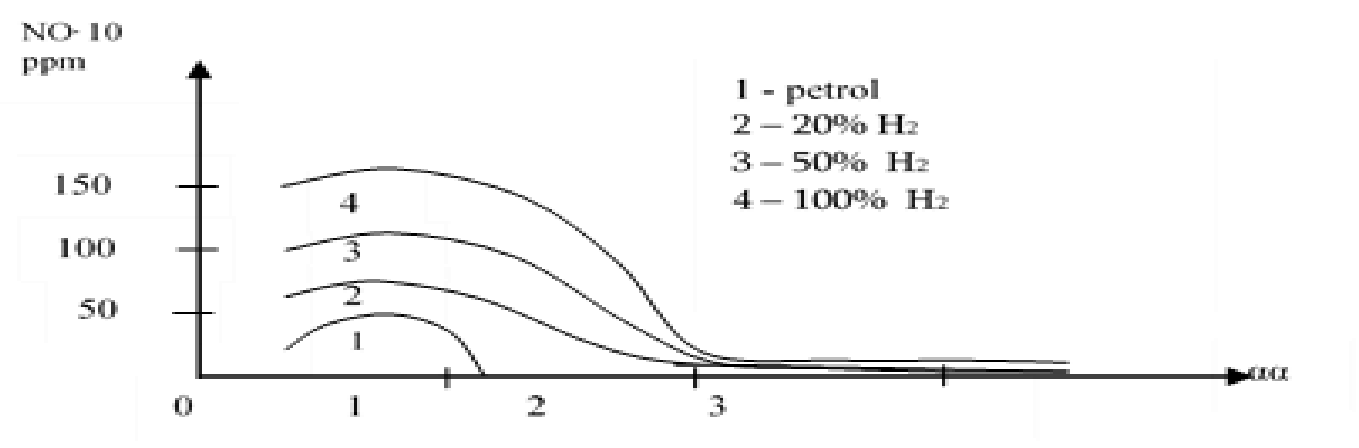

Fig. 4. The regulatory characteristics of engine in accordance with the composition of the fuel mixture, change in nitric acid concentration depending on $\alpha$ (gasoline)

As can be seen from the graph (Fig. 4), $\mathrm{NO}_{\mathrm{x}}$ is at a maximum when working on hydrogen. However, the mixture depletion reduces NO to zero $(\alpha \geq 2)$. Thus, by converting the engine to hydrogen, it is possible to solve the problem of the efficiency and toxicity. If we use hydrogen as an additive, it will help to increase the efficiency, reduce toxicity and reduce CO2. Figure 5 illustrates the change in carbon dioxide (CO) concentration depending on the excess-air coefficient when the engine is running on a gasoline-hydrogen mixture. The graph shows that CO can be reduced to zero during depletion of the fuel mixture. The additive in the range of $10 \div 20 \%$ may become optimal for hybrid vehicles in the near future.

The effective use of hydrogen as a fuel largely depends on the creation of a specialized engine design. The use of a lean mixture will allow us to reduce the temperature in the combustion chamber and create conditions for improving the compression quality. 


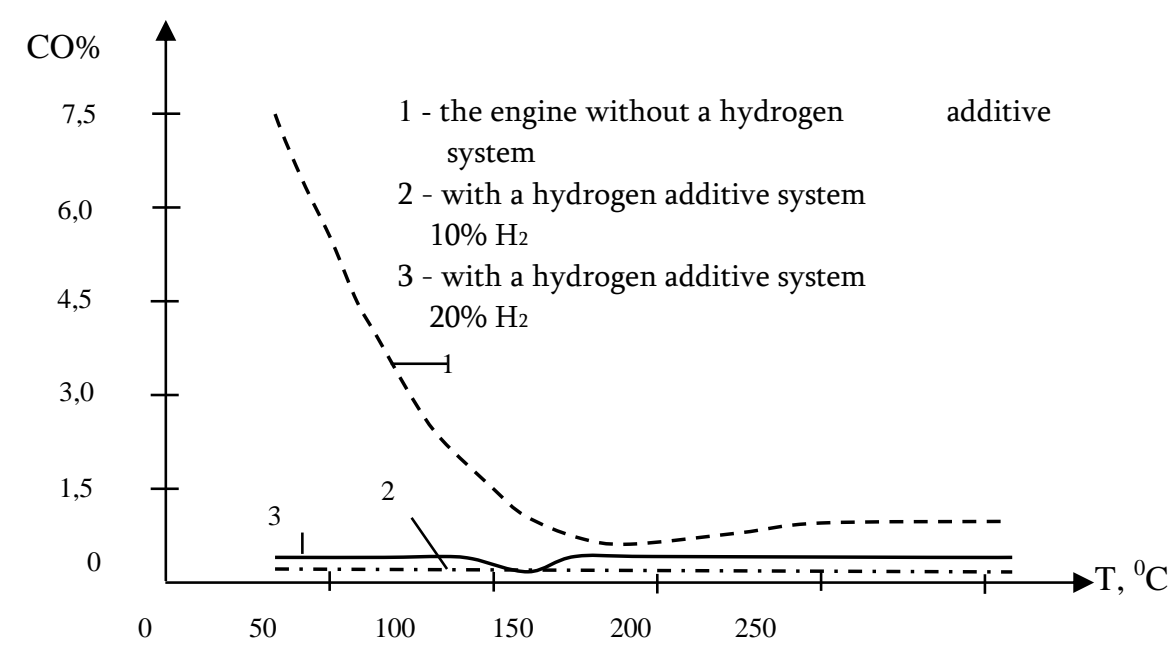

Fig. 5. The change in carbon dioxide (CO) concentration depending on the excess-air coefficient

\section{Conclusion}

Based on the studies conducted, it can be concluded that in idle and low load modes it is desirable for the engine to run at high hydrogen content in the fuel mixture, the increase in load should lead to the reduction of hydrogen concentration in the fuel mixture, and in full load mode, it must be stopped in order to preserve the power characteristics.

The use of hydrogen as an additive allows us to increase the efficiency rate to 40 , which is fully equal to the efficiency rate of the electro-chemical generator.

The use of the internal mixture allows us to improve by $20-30 \%$ the indicators of mass-topower ratio and dimensions of the engine.

\section{REFERENCES}

1. Bachana Markelia. Development of a technological process for using hydrogen obtained from hydrogen sulfide as an alternative fuel in transport internal combustion engines. Doctoral dissertation. Atsu. 2019140 p.

2. M.M. Rusakov et al. The effect of adding hydrogen on toxicity of ICE in starting and warm-up modes. Proceedings of the Russian Scientific -Technical Conference with international participation. No. 4. M.: 2016

3. Ramenskiy A.Yu. The use of hydrogen as a fuel for vehicles. The Engineering and Technical Center for Hydrogen Technology, 2015 


\section{USING DOING BUSINESS RATING FOR ASSESSING THE PRECONDITIONS OF SUSTAINABLE TRANSPORT AND ENVIRONMENTAL ECONOMICS DEVELOPMENT}

Kuzmenko H., I.

PhD in Economics, Associate Professor, Chief Researcher of the Research Institute of Economic Development, Kyiv National Economic University named after Vadym Hetman, Kyiv, Ukraine Shalimova N., S. Doctor of Economics, Professor, Dean of the Accounting and Finance Faculty, Professor of Department of Audit, Accounting and Taxation Central Ukrainian National Technical University, Kropyvnytskyi, Ukraine

Shalimov V., PhD in Economics, Associate Professor of Department of Finance, Banking System and Insurance, Central Ukrainian National Technical University,

The most popular international ranking in the world assessing the economic conditions is "Doing Business" which has existed since 2003 and is prepared by The World Bank Group. "Doing Business" index determines the quality of business regulations which enhance or constrain business activity, the use of the regulations in different countries, regions and selected cities.

"Doing Business" is the rankings which has existed since 2003 and is usually published in autumn. The number of countries covered by the ranking is constantly increasing: in 2017-2019190 countries. The studies indicate not only the problems that hold back business development but determine the cause and include recommendations on the necessary reforms.

Currently the international ratings "Doing Business" consist of 11 indicators including ten major and one extra (table 1). The additional indicator (11) describes the state of the labour market regulation, and its specificity is that it is not included in comprising the overall ranking (in 2011 a similar indicator was part of the main indicators). In 2017 it was introduced pilot indicator set "Selling to the government", but only in 2017, in subsequent years, it was not applied.

Table 1. "Doing Business" indicators

\begin{tabular}{|c|l|}
\hline \multicolumn{1}{|c|}{ Indicator } & \multicolumn{1}{|c|}{ Dasic } \\
\hline \multicolumn{2}{|c|}{ Description } \\
\hline & $\begin{array}{l}\text { reveals the bureaucratic and legal obstacles that an entrepreneur must } \\
\text { overcome in the process of creation and registration of a new company. The } \\
\text { total number of procedures as well as their costs and duration which } \\
\text { entrepreneurs must undergo to register a limited liability company from }\end{array}$ \\
\hline
\end{tabular}




\begin{tabular}{|c|c|}
\hline Indi & Description \\
\hline & pplying to the beginning of operation are determined \\
\hline $\begin{array}{c}\text { Dealing with } \\
\text { construction permits } \\
\text { (till } 2008 \text { - Dealing with } \\
\text { licenses) }\end{array}$ & $\begin{array}{l}\text { records all procedures required for a business in the construction industry to } \\
\text { build a warehouse along with the time and cost to complete each procedure; } \\
\text { deals with building regulations, including approvals, permit issuance and } \\
\text { inspections }\end{array}$ \\
\hline Getting ele & $\begin{array}{l}\text { records all procedures required for a business to obtain a permanent } \\
\text { electricity connection and supply for a standardized warehouse }\end{array}$ \\
\hline Registering property & $\begin{array}{l}\text { records the full sequence of procedures necessary for a business (the buyer) to } \\
\text { purchase a property from another business (the seller) and to transfer the } \\
\text { property title to the buyer's name so that the buyer can use the property for } \\
\text { expanding its business }\end{array}$ \\
\hline Getting credit & $\begin{array}{l}\text { measures the legal rights of borrowers and lenders with respect to secured } \\
\text { transactions through one set of indicators and the reporting of credit } \\
\text { information through another }\end{array}$ \\
\hline $\begin{array}{l}\text { Protecting minority } \\
\text { investors (till } 2014 \text { - } \\
\text { Protecting investors) }\end{array}$ & $\begin{array}{l}\text { measures the protection of minority investors from conflicts of interest } \\
\text { through one set of indicators and shareholders' rights in corporate governance } \\
\text { through another }\end{array}$ \\
\hline Paying taxes & $\begin{array}{l}\text { records the taxes and mandatory contributions that a medium-size company } \\
\text { must pay in a given year as well as the administrative burden of paying taxes } \\
\text { and contributions and complying with post-filing procedures }\end{array}$ \\
\hline Trading across borders & $\begin{array}{l}\text { records the time and cost associated with the logistical process of exporting } \\
\text { and importing goods (including the time for preparation of the required } \\
\text { documents) }\end{array}$ \\
\hline Enforcing contracts & $\begin{array}{l}\text { measures the time and cost for resolving a commercial dispute through a local } \\
\text { first-instance court and the quality of judicial processes index, evaluating } \\
\text { whether each economy has adopted a series of good practices that promote } \\
\text { quality and efficiency in the court system }\end{array}$ \\
\hline $\begin{array}{l}\text { Resolving insolvency } \\
\text { (till } 2011 \text { - Closing a } \\
\text { business) }\end{array}$ & $\begin{array}{l}\text { studies the time, cost and outcome of insolvency proceedings involving } \\
\text { domestic entities as well as the strength of the legal framework applicable to } \\
\text { judicial liquidation and reorganization proceedings. The data for the resolving } \\
\text { insolvency indicators are derived from questionnaire responses by local } \\
\text { insolvency practitioners and verified through a study of laws and regulations as } \\
\text { well as public information on insolvency systems }\end{array}$ \\
\hline \multicolumn{2}{|r|}{ Additional } \\
\hline $\begin{array}{l}\text { Labour market } \\
\text { regulation }\end{array}$ & $\begin{array}{l}\text { studies the flexibility of regulation of employment, specifically as it relates to } \\
\text { the areas of hiring, working hours and redundancy }\end{array}$ \\
\hline \multicolumn{2}{|r|}{ Pilot } \\
\hline $\begin{array}{l}\text { Selling to the } \\
\text { government (indicator } \\
\text { was applied only in } \\
\text { 2017) }\end{array}$ & $\begin{array}{l}\text { a pilot indicator set, which measures the ease of accessing and navigating } \\
\text { public procurement markets across } 78 \text { economies; the procurement process is } \\
\text { analyzed across five main areas: accessibility and transparency, bid security, } \\
\text { payment delays, incentives for small and medium-size enterprises and }\end{array}$ \\
\hline
\end{tabular}




\begin{tabular}{|l|l|}
\hline \multicolumn{1}{|c|}{ Indicator } & \multicolumn{1}{c|}{ Description } \\
\hline & complaints mechanisms \\
\hline
\end{tabular}

According to the report of 2020 Ukraine ranks 64 among 190 countries rated by "Doing Business - 2020" [3] which is sixteen position higher in comparison with the rating of "Doing Business - 2017" [2].

Table 2. Indicators of Ukraine, Lithuania and Slovenia according to "Doing Business - 2020" (World Bank Group, Doing Business-2020, 2019) and “Doing-Business - 2017” ((World Bank Group, Doing Business-2017, 2016)

\begin{tabular}{|c|c|c|c|}
\hline \multirow{3}{*}{ Indicator } & \multicolumn{3}{|r|}{ Ukraine } \\
\hline & \multirow[b]{2}{*}{2017} & \multicolumn{2}{|r|}{2020} \\
\hline & & Rank & $\begin{array}{c}\text { Rank within group “Europe \& } \\
\text { Central Asia” }\end{array}$ \\
\hline Population & $45,198,200$ & & $44,622,516$ \\
\hline GNI per capita (US\$S) & 2,620 & & 2,660 \\
\hline Ease of doing business rank & 80 & 64 & 18 \\
\hline Starting a business & 20 & 61 & 15 \\
\hline Dealing with construction permits & 140 & 20 & 4 \\
\hline Getting electricity & 130 & 128 & 19 \\
\hline Registering property & 63 & 61 & 16 \\
\hline Getting credit & 20 & 37 & 12 \\
\hline Protecting minority investors & 70 & 45 & 11 \\
\hline Paying taxes & 84 & 65 & 15 \\
\hline Trading across borders & 115 & 74 & 18 \\
\hline Enforcing contracts & 81 & 63 & 17 \\
\hline Resolving insolvency & 150 & 146 & 23 \\
\hline
\end{tabular}

A more detailed analysis of indicators presented in table 3.

Table 3. Indicators of Ukraine in "Doing Business - 2020"

\begin{tabular}{|l|l|c|}
\hline \multicolumn{1}{|c|}{ Topics } & \multicolumn{1}{|c|}{ Indicator } & Ukraine \\
\hline \hline \multirow{4}{*}{$\begin{array}{l}\text { Starting a } \\
\text { business }\end{array}$} & Procedures (number) & 6 \\
\cline { 2 - 3 } & Time (days) & 6.5 \\
\cline { 2 - 3 } & Cost (\% of income per capital) & 0.5 \\
\cline { 2 - 3 } & Minimum capital (\% of income per capita) & 0.0 \\
\hline \hline $\begin{array}{l}\text { Dealing with } \\
\text { construction } \\
\text { permits }\end{array}$ & Procedures (number) & 10 \\
\cline { 2 - 3 } & Time (days) & 72.5 \\
\cline { 2 - 3 } & Cost (\% of warehouse value) & 4.4 \\
\hline
\end{tabular}




\begin{tabular}{|c|c|c|c|}
\hline \multirow[t]{2}{*}{ Topics } & \multicolumn{2}{|r|}{ Indicator } & Ukraine \\
\hline & \multicolumn{2}{|c|}{ Building quality control index (0-15) } & 12.0 \\
\hline \multirow{4}{*}{$\begin{array}{l}\text { Getting } \\
\text { electricity }\end{array}$} & \multicolumn{2}{|c|}{ Procedures (number) } & 5 \\
\hline & \multicolumn{2}{|c|}{ Time (days) } & 267.0 \\
\hline & \multicolumn{2}{|c|}{ Cost (\% of income per capital) } & 353.2 \\
\hline & \multicolumn{2}{|c|}{ Reliability of supply and transparency of tariffs index (0-8) } & 7 \\
\hline \multirow{4}{*}{$\begin{array}{l}\text { Registering } \\
\text { property }\end{array}$} & \multicolumn{2}{|c|}{ Procedures (number) } & 7 \\
\hline & \multicolumn{2}{|c|}{ Time (days) } & 15.0 \\
\hline & \multicolumn{2}{|c|}{ Cost (\% of property value) } & 1.7 \\
\hline & \multicolumn{2}{|c|}{ Quality of land administration index (0-30) } & 16 \\
\hline \multirow{4}{*}{ Getting credit } & \multicolumn{2}{|c|}{ Strength of legal rights index (0-12) } & 8 \\
\hline & \multicolumn{2}{|c|}{ Depth of credit information index $(0-8)$} & 7 \\
\hline & \multicolumn{2}{|c|}{ Credit bureau coverage (\% of adults) } & 56.9 \\
\hline & \multicolumn{2}{|c|}{ Credit registry coverage (\% of adults) } & 2.4 \\
\hline \multirow{6}{*}{$\begin{array}{l}\text { Protecting } \\
\text { minority } \\
\text { investors }\end{array}$} & \multicolumn{2}{|c|}{ Extent of disclosure index (0-10) } & 9.0 \\
\hline & \multicolumn{2}{|c|}{ Extent of director liability index (0-10) } & 2.0 \\
\hline & \multicolumn{2}{|c|}{ Ease of shareholder suits index $(0-10)$} & 6.0 \\
\hline & \multicolumn{2}{|c|}{ Extent of shareholder rights index (0-10) } & 4.0 \\
\hline & \multicolumn{2}{|c|}{ Extent of ownership and control index (0-10) } & 6.0 \\
\hline & \multicolumn{2}{|c|}{ Extent of corporate transparency index $(0-10)$} & 7.0 \\
\hline \multirow{8}{*}{$\begin{array}{l}\text { Trading across } \\
\text { borders }\end{array}$} & \multirow{2}{*}{$\begin{array}{l}\text { Time to } \\
\text { export }\end{array}$} & Documentary compliance (hours) & 66 \\
\hline & & Border compliance (hours) & 6 \\
\hline & \multirow{2}{*}{$\begin{array}{l}\text { Cost to } \\
\text { export }\end{array}$} & Documentary compliance (US\$) & 192 \\
\hline & & Border compliance (US\$) & 75 \\
\hline & \multirow{2}{*}{$\begin{array}{l}\text { Time to } \\
\text { import }\end{array}$} & Documentary compliance (hours) & 48 \\
\hline & & Border compliance (hours) & 32 \\
\hline & Cost to & Documentary compliance (US\$) & 162 \\
\hline & import & Border compliance (US\$) & 100 \\
\hline & Time (da & & 378 \\
\hline contractc & Cost $(\%$ & aim) & 46.3 \\
\hline & Quality & dicial processes index (0-18) & 11.5 \\
\hline & Time (ye & & 2.9 \\
\hline & Cost $(\%$ & tate) & 40.5 \\
\hline incolvenge & Recover & (cents on the dollar) & 9.0 \\
\hline & Strength & nsolvency framework index (0-16) & 11.2 \\
\hline & Outcom & as piecemeal sale and 1 as going concern) & 0 \\
\hline
\end{tabular}

The more favorable position of Ukraine on "dealing with construction permits" is a consequence of a significantly smaller number of procedures and the requested time, despite the almost identical level of cost (\% of warehouse value) and building quality control index. Despite the same level of cost (\% of claim) and the same level of judicial processes index in terms of enforcing contracts, Ukraine also has a higher position due to the smaller number of required days.

Over the 17 years of its existence, the Doing Business report has been a valued tool for 
countries seeking to measure costs of doing business. Doing Business indicators and methodology are designed with no single country in mind, but rather to help to improve the overall business climate.

On August 27, 2020 The World Bank Group issued the following statement on the Doing Business Report [1]. A number of irregularities have been reported regarding changes to the data in the Doing Business 2018 and Doing Business 2020 reports, published in October 2017 and 2019. The changes in the data were inconsistent with the Doing Business methodology.

The integrity and impartiality of our data and analysis is paramount and so World Bank are immediately taking the following actions:

- conducting a systematic review and assessment of data changes that occurred subsequent to the institutional data review process for the last five Doing Business reports;

- the World Bank Group's independent Internal Audit function has been asked to perform an audit of the processes for data collection and review for Doing Business and the controls to safeguard data integrity.

World Bank will act based on the findings and will retrospectively correct the data of countries that were most affected by the irregularities. The publication of the Doing Business report will be paused as World Bank conduct assessment.

Conclusions. The further increasing of the ranking in the world economy in general and in different areas in particular (trade, financial, social, etc.) is impossible without forming a solid basis for internal development by improving institutional, administrative and economic instruments in this sphere. The results of such comparative analysis will allow identifying risk areas, and relevant information can be used in developing of recommendations and proposals for improving the effectiveness of the operation environment. However, it is important to avoid activities that "artificially" increase the ranking without real improvement as this may adversely affect the image and reputation of the country causing distrust to the governance.

\section{REFERENCES}

1. Doing Business - Data Irregularities Statement Retrieved from https://www.worldbank.org/en/news/statement/2020/08/27/doing-business---data-irregularitiesstatement

2. Doing Business 2017. Equal Opportunity for All. www.doingbusiness.org. Retrieved from http://www.doingbusiness.org/reports/global-reports/doing-business-2017

3. Doing Business 2020. Equal Opportunity for All. www.doingbusiness.org. Retrieved from https://www.doingbusiness.org/en/reports/global-reports/doing-business-2020 


\section{SOCIAL RESPONSIBILITY OF BUSINESS IN THE CONDITIONS \\ OF SPREADINGS COVID-19}

Lopushniak H.S.,

ScD in Economics, Professor,

Kuzmenko H.I.,

Ph.D. in Economics, Honored Economist of Ukraine

Kravchuk O.I.

Ph.D. in Economics, Associate Professor

Kyiv National Economic University named after Vadym Hetman,

Kyiv, Ukraine

The spread of the COVID-19 pandemic has not only necessitated to rethink health care approaches, but has also created new business challenges. In particular, the introduction of quarantine restrictions was a real challenge for all enterprises without exception, which some of them failed to cope with, and that led to their closure. This, in turn, determined the existing risks in Ukraine, as in many other countries: rising unemployment, declining incomes and quality of life, increasing social inequality, narrowing markets for finished products and more. At the same time, digital technologies, which are rapidly developing and being widely implemented in various spheres of the world economy, have opened new opportunities for business, while creating additional challenges.

In such conditions, one of the main components of a civilized economy is corporate social responsibility (CSR). After all, the spread of responsible business practices with the assistance of the government will provide an opportunity to build a sustainable future of a particular state, in which each subject of society will feel its demand, take responsibility and act for the common good.

It is now quite difficult to predict what consequences of Covid-19 will be for the population, business and the global economy in general. Despite the titanic efforts of most governments to minimize the risk of Covid-19 pandemic, the virus has killed 3.7 million people and reduced the activity of many businesses, reversed global economic trends and prompted people to think more seriously about the creation of a safe environment for life. It is obvious that without an active position and help from business, it will be impossible to achieve this goal in any country in the world.

Analyzing the CSR practices of Ukrainian companies during the spread of the Covid-19 pandemic, it is found that they pay the most attention to initiatives and projects that help minimize the risks associated with the spread of the virus. It is important that the implementation of measures within the framework of these initiatives also contributes to the achievement of sustainable development goals. Priority for Ukrainian business in 2019 - 2020 were: Goal 4 "Quality education", Goal 8 "Decent work and economic growth" and Goal 3 "Strong health and 
well-being" [2]. In 2021, the main focus is on achieving Goal 3 as there is an increased risk to workers' health in the context of the Covid-19 pandemic.

Among the most common initiatives and projects within the framework of CSR, which were carried out by Ukrainian enterprises, it should be noted: the transition (if possible) to remote employment and the provision of office equipment for home work; providing employees with personal protective equipment; purchase of systems for diagnosis of infectious diseases; charitable financial and other (free repair of ambulances; purchase of ambulances, ventilators and other medical equipment, protective suits, etc.) assistance to hospitals; free delivery of their products to doctors and the elderly; providing financial assistance to doctors who treat patients with COVID-19; providing free meals to medical staff of hospitals and laboratories that are in the highest risk area.

As mentioned above, the introduction of quarantine restrictions has created new challenges for business and increased the importance of digital technologies for its development. This trend will inevitably lead to increasing inequality, and not only digital, increasing poverty, reducing social cohesion and so on. This is confirmed by the WEF forecasts, which report [g] states that "the immediate human and economic losses from COVID-19 are very serious. They threaten to nullify many years of progress in the fight against global poverty and inequality, as well as further harm social cohesion and global cooperation"[g]. At the same time, this trend has necessitated an increase in digital literacy not only of staff but also of the entire population. And this is a challenge that needs to be responded quickly, because the development of not only national but also the world economy depends on it. The higher the level of digital literacy of the personnel at enterprises of different forms of ownership - the higher the chances of such enterprises are to establish uninterrupted work in the new socio-economic reality. However, it should also be borne in mind that consumers must also have a sufficient level of digital literacy to be able to take advantage of new procedures for ordering, purchasing and delivering goods or providing services. Therefore, CSR activities should include not only training programs for their employees, but also training programs for potential consumers, which in turn will contribute to the goal of sustainable development "Quality education".

In essence, all business structures can use the goals of sustainable development as a basic platform for the formation or adjustment of their business strategies to strengthen their responsibility to employees, potential consumers and future generations. In particular, by producing quality products that meet international standards, each manufacturer will not only become more competitive in world markets, but also help improve the health of the population (through their food, clothing, household items, etc.).

Decent remuneration for work and inclusion in the social package of services such as paying for gym memberships and/or equipment at the rooms of psychological and emotional relief rooms, gyms, organization of healthy nutrition of employees will also contribute to the well-being of employees and their families, promote healthy lifestyles, reduce level of poverty, as well as increasing productivity and production. This will mitigate the effects of COVID-19. 
Installation of modern treatment plants at enterprises, as a result of which environmental pollution is possible, and rational use of natural resources will help to achieve environmental goals of sustainable development and promote the introduction of innovative technologies into production, thereby increasing the competitiveness of enterprises.

It is important to note that the success of any business project largely depends on the environment in which they are implemented. It is particularly important: the existence of open to society and free from corruption public and financial institutions with quality management and transparent procedures for their activities; properly formed regulatory framework for business regulation, the provisions of which indicate the ease of doing business and effective social protection systems.

The presence of common goal for business, government and citizens that is stated for sustainable development, allows to outline topics for discussion and contributes to the formation and implementation of policies in terms of social partnership, taking into account the principles of social responsibility.

Conclusions. In view of the above, it can be argued that the creation of socially responsible organizations will mitigate the negative effects of COVID-19, as well as contribute to the goals of sustainable development, as their activities are aimed not only at profit and financial stability, but also at production of consumer-safe goods and services that improve the quality of life and reduce the destructive impact on the environment.

\section{REFERENCES}

1. The Global Risks Report 2021, 16th Edition: insight report. World Economic Forum, 2021. $97 \mathrm{p}$.

2. The contribution of Ukrainian business to the implementation of Ukraine's Sustainable Development Goals 2016-2020, 2021. 23. https://csr-ukraine.org/wpcontent/uploads/2020/12/Vpliv-biznesu-na-CSR.pdf 


\section{COOPERATIVES IN THE MODERN WORLD}

Sanikidze H. M.

Doctoral Student of Batumi Shota Rustaveli State University

Batumi, Georgia

It is widely believed that by 2050 , most of the additional food needed to feed more than nine billion people will come from smallholders. One of the necessary steps to achieve food security is to support and invest in cooperatives, producer organizations, and other rural institutions.

Numerous successful examples from around the world have shown that rural institutions such as producer organizations and cooperatives contribute to food security by making it easier for smallholders, fishermen, livestock breeders, forest owners, and other producers to access the information, tools, and services they need. This allows them to increase food production, sell their goods and create jobs, improving their own living conditions and increasing food security in the world.

Most small producers in developing countries face many challenges. They are often very far from what is happening in national and international markets. To benefit from the current situation, food price increases must be communicated to all members of the value chain, down to small producers.

Farmers also face difficulties in gaining access to high-quality inputs. While the selling price of crops can rise before deciding to expand production, farmers also have to take into account the variable costs of purchasing seeds and fertilizers. Problems may arise with obtaining access to loans to purchase these resources. Even if all these conditions are favorable, many small producers face other obstacles, such as lack of transport to get their products to local markets or lack of adequate infrastructure in rural areas. For all these reasons, higher prices in international markets did not translate into higher incomes and wealth for small producers in developing countries.

However, there is some good news. Accumulated research data and experience shows that while acting alone did not benefit farmers from higher food prices, those acting collectively within strong producer organizations and cooperatives were able to better seize market opportunities and mitigate the negative impact of the food crisis. and other crises. The aim of this paper is to deepen understanding of the role of agricultural cooperatives and producer organizations and their implications for achieving food security and poverty reduction.

As a way to defeat hunger and poverty, he recommends promoting these special ventures. It highlights the need to empower and support the growth and sustainability of agricultural and food cooperatives. It also recommends that governments and policymakers implement appropriate policies, transparent legislation, incentives, and opportunities for dialogue, all of which are prerequisites for the development and growth of cooperatives and producer organizations. 
A range of services By offering their members a range of services, strong cooperatives, and other producer organizations can overcome challenges such as those described above. These services include access to natural resources, information, communications, markets for capital goods and products, and technology and training. They also facilitate their participation in decision-making processes. Through methods such as group buying and group marketing, farmers gain a foothold in the market and get the best prices for agricultural inputs and other necessities.

Cooperatives and producer organizations play a central role in building the skills of small producers by providing them with the information and knowledge they need, helping them innovate and adapting to changing market conditions. Some of these give farmers the opportunity to build the capacity to analyze their production systems, identify problems, test possible solutions, and, ultimately, implement the methods and technologies that are most appropriate for their farming systems. In addition, cooperatives and producer organizations make a significant contribution in helping small producers to voice their concerns and interests, and ultimately to strengthen their position and empower them to influence policy-making processes.

Examples of where manufacturers can discuss and government agencies are "multistakeholder platforms" and advisory forums. United Nations Security Council on International Security. It features stakeholders, intergovernmental organizations, regional and international producer organizations, and other key partners, under the auspices of the UN Food and Agriculture Organization.

\section{Conclusion}

In this way, they contribute to efforts to ensure food security and end hunger. Cooperatives in the economy, including agriculture, finance, health care, insurance, and loans. There are one billion people worldwide, employing over one hundred million jobs worldwide. It has come to reinforce these and strengthen the promotion of their expansion, creating a conducive business, legal and social environment in which they can thrive.

\section{REFERENCES:}

1. Mescon M.Kh. Fundamentals of Management / H. M. Mescon, M. Albert, F. Hedouri; Per. from English; Common ed. JI. I. Evsenko. Moscow: Delo, 1992, 702 p.

2. Okumura H. Corporate Capitalism in Japan IX. Okumura; Per. with jap.; Sci. ed. A. Ya. Pevzner. Moscow: Mysl ', 1986, 250 p.

3. Simmons D. How to become an owner. American Experience of Employee Participation in Property and Management / D. Simmons, W. Mere; Per. from English A. N. Isaenko, O. V. Tikhonova; Sci. ed. A. A. Voronkov. Moscow: Argumenty i Fakty, 1993, 299 p.

4. Tugan-Baranovsky M.I. Courses in cooperation. T. I / M. I. Tugan-Baranovsky. M., 1906, 207 p.

5. Tugan-Baranovsky M. I. Social foundations of cooperation / M. I. Tugan-Baranovsky ', Moscow City University. 2nd ed. M., 1918, 498 p. 


\title{
CHANGES IN THE PRACTICE OF CONSUMER BEHAVIOR DUE TO COVID-19 AND OPPORTUNITIES FOR NEW TOURISM COUNTRIES
}

\author{
Kochlamazashvili L., \\ Professor of the Faculty of Business Technologies, \\ Technical University of Georgia \\ Katsitadze N., \\ Associate Professor of the TSU \\ Department of Tourism and Hospitality Management \\ Tushishvili N., \\ PhD student
} School of business and technology, DAUG.

The crisis caused by Covid-19 turned out to be unprecedented in terms of its scale and its duration. In 2020, the number of international arrivals decreased by 1 billion, which is equivalent to $74 \%$. Loss of international tourism receipts amounted to $\$ 1.3$ trillion. The losses caused by Covid-19 are 11 times higher compared to the losses caused by the 2009 global financial crisis [1]. Even after one year from the beginning of the outbreak of the pandemic, the future of tourism is still not clear.

Not a single country around the world could avoid significant losses caused by the crisis in tourism sector. The countries in which the tourism contribution to the economy is relatively high, more than $20 \%$ on average, found themselves in a particularly difficult position. Georgia also belongs to such countries. In 2019, tourism receipts amounted to $\$ 3.3$ billion $-34 \%$ of total revenues from exports of goods and services (\$ 9.5 billion) [1]; [2].

Disasters and other such events filter out the impact of key indicators of tourism and the negative consequences caused by the crisis in tourist destinations depend on the factors such as: dependence of the country/region on tourism; the level of tourism diversification; the size of the internal market; security issues and the image of the country; changing the behavior of travelers.

One of the most problematic issues among the various challenges facing the tourism industry is changes in consumer behavior in the tourism market, which are the most difficult to predict [3]. The crisis creates new views and demands in consumers that can lead to the transformation of the industry. This circumstance calls for a drastic change in the existing practice of tourism management.

Historically, tourism has shown strong capacities for adapting to crises, innovations and recovering from shock. Recent trends in Europe show that opening of borders and tourism are not free from risks. An increase in the spread of the infection has forced governments to impose restrictions. Tourism, which is based on the movement of people from their usual living environment, contradicts with the main mechanism to stop the pandemic, which represents a challenge for the industry planners. 
Tourists are sensitive to crises. Every global crisis has caused anxiety, confusion and various fears in consumers. Tourism behavior is formed based on the influence of both internal (motivation, attitude, belief, etc.) and external (economic environment, security, socio-cultural environment, etc.) factors. Among these factors, safety is the most important for travelers [4].

The concept of today's new consumer caring for one's own health and welfare suggests that when buying a tourism product, the perception of life and health risks will be crucial in travelers' decision making [5]. Therefore, the process of buying in the tourism market will be the search for low-risk alternatives and there will be demand for tourism destinations that provide an environment where tourists feel safe.

Restoring confidence in tourists, promoting domestic tourism and ensuring the safe return of international tourism, providing clear information to travelers and limiting uncertainty (as far as possible), enhancing cooperation inside the countries and among them represent priority policy areas for the countries who want to stay competitive in tourism market.

The trends revealed as a result of the social survey of the domestic and outbound tourism market of Georgia and the study on the example of Russia regarding the inbound tourism of Georgia carried out to identify the possible changes in the behavior of consumers in the tourism market showed some key similarities. These are more emphasis on health and therefore more caution due to fears of infection as evidenced by their focus on avoiding crowded destinations and search for sanitation and new, safer and more environmentally friendly alternatives. Such peculiarities of tourist behavior might become a trend in the near future and lead to the end of mass tourism.

The pandemic crisis accompanied by economic crisis in the global market resulted in its usual reaction in tourist behavior - increased sensitivity to prices; the trends such as: avoiding traveling to crowded destinations and looking for alternatives; paying particular attention to the level of health care and sanitation of tourist facilities in the host country; increased demand for eco-friendly tourist destinations. New spending and travel planning strategies show significant changes in the practice of customer behavior leading to the transformation of the industry.

The crisis has shocked the tourism industry, but at the same time has opened new opportunities for the future of tourism. Changes in consumer practices in the tourism market will result in the development of many new tourism destinations. This change can be effectively used by countries with small economies, where, in many case, there is the potential to meet the growing demand for ecotourism [6].

Tourism is at a crossroads and the actions taken today shape tomorrow's tourism. Governments need to take into account the long-term impact of the crisis; however, the practice observed in many countries showing that success depends not so much on the availability of resources but more on the utilization of these resources through using the innovative methods of management should be also taken into consideration [7]. Sustainable development of a tourist destination involves effective anti-crisis strategies and timely response to the existing challenges. 


\section{REFERENCES}

1. UNWTO World Tourism Barometer Vol 19, No 1, January 2021, URL: https://www.e-unwto.org/toc/wtobarometereng/19/1;

2. GNTA-Georgian Tourism Administration, Annual Report 2019, URL: https://gnta.ge/statistics/

3. Mair, J., Ritchie, B. W., \& Walters, G. (2016). Towards a research agenda for postdisaster and post-crisis recovery strategies for tourist destinations: A narrative review. Current Issues in Tourism, 19(1), 1-26.

4. Maslow, A. H. (1943). A theory of human motivation. Psychological Review, 50(4), 370

5. Sönmez, S. F., \& Graefe, A. R. (1998). Determining future travel behavior from past travel experience and perceptions of risk and safety. . Journal of Travel Research, 37(2), 171-177.

6. Katsitadze N. I.Natsvlishvili (2020). The Role of State Regulatios and Policy in Tourizm Development: The Case of Georgia Part of the Eurasian Studies in Business and Economics book series (EBES, volume 13/1

7. Katsitadze N. (2018) State Policy in Tourism - Business (MICE) Tourism in Georgia, “Economics and Business," vol. XI, \#4, pp.127-145, 


\section{AN APPROACH TO TRAINING MANAGERS AND ENTREPRENEURS FOR CREATIVE INDUSTRIES}

Shymanovska-Dianych L.M., Doctor of economic science, professor, Poltava University of Economics and Trade, Poltava,

Ukraine

Ishcheikin T.,

Ph.D. in Economics, Associate Professor, Poltava State Agrarian Academy, Poltava, Ukraine

One of the modern and effective approaches to training managers and entrepreneurs for creative industries, which is implemented at the Poltava University of Economics and Trade, is the project approach. The relevance of the proposed project "EU experience in developing entrepreneurial skills in higher education for the creative industries" is due to the fact that creative industries are a modern phenomenon of interaction between business, politics, culture and education, which is the production and distribution of goods and services created on the basis of creativity and intellectual capital. For foreign countries, creative industries represent a kind of crossroads of ideas, culture, business and technology. During the period 2002-2020, the world market for creative industries more than doubled, from \$208 to \$609 million. In developed economies, the contribution of creative industries to GDP is more than $10 \%$, but in Ukraine it does not yet exceed $3 \%$. The world average contribution of creative industries to GDP is $6.6 \%$, in developed countries - 8-12\%.

Modern creative industries refer to the creative principle of human activity in any of its manifestations, are inextricably linked with copyright and are capable of creating wealth and highly productive jobs. Characterizing the creative industries as a leading factor in the civilizational shift, modern researchers see in them a fundamentally new model of socio-economic growth, a source of modernization and a driving force of innovation and strengthening of the social fabric. Cultural and creative industries help revitalize national economies, create jobs and promote local development. To create a successful creative business, a good idea is not enough - you need skills and knowledge to develop it, as well as start-up capital.

The process of formation of creative industries in Ukraine today is going faster than educational and training programs for industry representatives are changing and developing. The modern creative environment lacks professionals capable of strategic development of innovative ideas and projects and their successful commercial implementation in a rapidly changing global market. Therefore, the development of entrepreneurial skills in the field of creative industries is of great relevance, since it contributes to the formation of a creative economy in an information society and a creative personality and is formed on its assets that can generate economic growth and development, which is based on the development of human capital. To achieve these goals, a critical mass of "people of creators" should appear in the information society, whose main goal is social and economic changes in Ukraine. In this regard, it is necessary to form a new model of 
training personnel capable of developing creative entrepreneurship in the country and developing a creative personality.

Conclusion.The mission of the project "EU experience in developing entrepreneurial skills in higher education for the creative industries" is to popularize both European practices in the development of entrepreneurial skills in higher education for creative industries and specific creative projects in Europe and Ukraine by studying them and taking direct part in them. The implementation of the project "EU experience in developing entrepreneurial skills in higher education for the creative industries" allows to achieve the goals and solve the tasks that we propose to divide into two blocks: the goals and objectives of research and improvement of the process of developing entrepreneurial abilities.

\section{REFERENCES}

1. Совет Европейского Союза (2015г.).Точки соприкосновения в ИКТ для стимулирования инноваций, экономической устойчивости и социальной интеграции. Заключения Совета, Брюссель. http://eur-lex.europa.eu/legalcontent/EN/TXT/HTML/?uri=CELEX:52015XG0527(03)\&from=EN

2. Европейская сеть креативных хабов (2016 г.) Как работает работа: перечень эффектов, Nova Iskra/Kulturni Kod, Белград http://creativehubs.eu/wpcontent/uploads/2016/10/How_Work_Works-Publication-PDF_Preview.pdf

3. The Gelsenkirchen Declaration on Institutional Entrepreneurial Management and Entrepreneurial Studies in Higher Education in Europe // Higher education in Europe. 2004. V. 29. № 2. 


\section{CONTEMPORARY PROBLEMS OF THE ENTERPRISE MANAGEMENT PROCESS}

Chechelashvili M., Doctor of Economics (Ph.D) Associate Professor of Georgian Technical University Tbilisi, Georgia

The effective development of industrial enterprises in Georgia at the present stage of the development of the national economic system is complicated by two circumstances:

a) the state and prospects of the external environment, a distinctive feature of which is the development of the phenomena of post-crisis economic stagnation,

b) the raw material orientation inherent in the domestic economy, which is increasing against the background of the global transition to the knowledge economy.

The development of industrial economic entities in the knowledge economy presupposes the need to increase the efficiency of using the organizational, human and informational potential of an enterprise, which is impossible in the absence of the practice of using management mechanisms focused on innovative development. Their implementation should be aimed at the rational distribution of limited human, information, and time resources, ensuring the progressive dynamics of organizations, which, in turn, dictates the need to restructure the processes of organizing management as a basic function of managing business entities in the production sphere.

Many scholars consider the terms innovative economy, new economy, and knowledge economy as synonymous. According to other authors, each of these terms has its own definition, origin, and purpose. The need to study the similarities and differences in the content of each of them is associated with the need for operationalization and use in managing the economy, as well as the enterprise, its capital, and value. The importance of comparing terms becomes more relevant in connection with the solution of the problem of building an innovative economy in Georgia. An economy of this type, according to many scientists, is capable of providing:

a) Sustainable development of the country,

b) Acceleration of scientific and technological progress,

c) Qualitative changes in the market and in societies.

Georgia has not yet succeeded in innovative construction, since in the rating of innovative states it is in 38th place out of 50 possible, behind the Baltic countries, the Czech Republic, and Turkey.

The term innovative economy has a dependent word that clarifies the meaning of this term - innovative. Therefore, it is such an economy, the functioning, and development of which is associated with innovation. Wikipedia gives the following definition: "An innovative economy (knowledge economy, intelligent economy) is a type of economy based on the flow of innovations, on constant technological improvement, on the production and export of high-tech products with 
very high added value and the technologies themselves." It is assumed that in this case, profit is mainly created due to the intelligence of innovators and scientists, the development and use of the information sphere, and not due to material production (as in an industrial economy) and not due to the concentration of finance (capital).

It is difficult to recognize this definition of the corresponding reality since in Georgia, in different historical periods, innovations were borrowed from abroad and an innovative economy was built on the basis of borrowed innovations. Now it is becoming a kind of tradition. But it should be noted that China, Japan, South Korea, and many other countries did (and continue to do so) in their time. In world practice, trade in licenses for innovative technologies and the production of innovative goods is widespread.

In this way:

- $\quad$ First, the national economy can be innovative if: a) the simplest and most effective innovations based on old knowledge are created and successfully introduced; b) new knowledge is not created, but innovations are borrowed;

- Secondly, self-created improving innovations used in the national economy can be based on new knowledge (in this case, we can talk about the existence of a knowledge economy) or on previously known knowledge (in this case, an innovative economy does not have the features of a knowledge economy);

- $\quad$ Third, a new (national) economy can be built: a) on the basis of new knowledge created in the country, which allows us to speak about the formation of a knowledge economy in it; b) on borrowing high-tech industries;

- $\quad$ Fourth, the rational option, according to the authors, is a reasonable combination of

a) Borrowing and our own developments based both on the acquired abroad and on the new knowledge created in the country;

b) Innovative and knowledge-based development of traditional industries and priority growth of industries and spheres of activity that are at the forefront of scientific and technological progress, which are a priority and critical at the present historical stage.

At the same time, a qualimetrically reasonable combination can be obtained on the basis of the formulation and solution of the strategic problem of effective distribution of income for consumption and accumulation, taking into account the prospects for the development of hightech industries.

It is advisable to note that in the leading developed countries in high-tech industries and spheres of activity, no more than $10 \%$ of the workforce is employed but it is these industries that play the role of the locomotive of scientific and technological progress.

Conclusion. Separation of the studied concepts, highlighting their distinctive and similar sides allows us to clarify what factors, mechanisms, and tools should be used to build an innovative economy and an enterprise, to answer the question: will this be a new knowledge economy? Consequently, it becomes possible to operationalize concepts in order to build effective management of an enterprise, its capital, and value in an innovative economy, a knowledge 
economy, and a new economy. The result of the research can be presented as a certain desired area in which an enterprise should fall, striving to survive and develop sustainably in the modern global economy.

Thus, modeling the state of the enterprise and the processes of its change, it is possible to identify factors and indicators that will correspond to the goals of the innovative subject of the national economy, creating and/or using new knowledge and modern information and communication technologies and means.

\section{REFERENCES}

1. M. Chechelashvili, G. Kurashvili, A. Bolkvadze, "Frugal Production as a Mechanism for Increasing Product Quality and Production Cost Efficiency", Proceedings of the 2nd GTU International Conference "Globalization and Modern Business Challenges", May 25-26, Tbilisi, 2018TQM - Total Quality Management - bumnobob asmorzob unbsిjas http://www.csrjournal.com/lib/analiticarticle/1759-issledovanie-iz-rossii-s-ljubovju.nacionalnyjj.html

2. B2B - Business to Business - Business to Business; B2C - Business to Consumers Business to Consumers http://www.leaninfo.ru/2011/10/17/ps-eto-lyudi/

3. Eels R., Walton C. Conceptual foundations of business // Homewood: Richard D. Irwin, Inc., 1961.

4. Freeman R.E., Phillips R.A. Stakeholder Theory: A Libertarian Defense // Business Ethics Quarterly. - 2002. - 12(3): pp. 331-349.

5. Preston L.E., Post J.E. Prvate Management and Public Policy. The Principle of Public Responsibility - Englewood Cliffs, NJ: Prentice Hall, 1975.

6. Matten D., Crane A. Corporate Citizenship: Toward an Extended Theoretical Conceptualization // Academy of Management Review. - 2005. - 30(1): pp.166-179.

7. McKinsey Global Institute, URL:http://gtmarket.ru/files/news/1986/MGI_Effective_Russia_Productivity_Growth_as_the_Fou ndation_2009.pdf

8. Rawls J. A theory of justice - Cambridge, MA: Belknap Press, 1971 


\section{SUSTAINABLE FOOD SECURITY CHALLENGES AND AGRIBUSINESS DEVELOPMENT NEEDS}

Suknishvili M. G.,

Doctoral Student of Batumi Shota Rustaveli State University,

Batumi, Georgia

The development of agribusiness is of particular importance in any country for solving the food security problem. This problem is also relevant for Georgia, as there is an increase in food prices, inflation, a negative trade balance between exports and imports of agri-food products, etc.

The spread of COVID-19 has made the need to develop agribusiness even more urgent. The pandemic affected all areas of the economy and public life, including agribusiness. Due to the coronavirus, new challenges have emerged in the domestic and international food markets. According to Deutsche Welle, global overcoming coronavirus will require more than $\$ 4.1$ trillion, mobilization of which, in turn, will further deepen the ongoing food crisis in the world ${ }^{1}$. The United Nations estimates that a "biblical scale" famine is expected in the world if radical and optimal decisions are not made in the short period in accordance with the requirements, formed with a background of pandemic. Today, 135 million people in the world are starving, and that number could rise to 250 million. The food crisis was even before the pandemic, for example, the food crisis in South Sudan alone affected 61\% of the population in 2019. Before coronavirus pandemic, food shortages had already existed in East Africa and South Asia for decades, and further aggravation is expected ${ }^{2}$.

Planning these actions and developing recommendations will not be easy. I would like to quote academician Lado Papava on post-crisis expectations (April 3, 2020). According to Mr. Papava, this crisis is qualitatively different from the previous economic crisis, because its basis is not in the economy alone. Recently, new demands have been identified in the field of agribusiness, in particular, demand for the sale of agri-food products through digital channels, as well as the development of electronic communications became relevant. Most of the economic decisions in agribusiness were already made in conditions of uncertainty. The likelihood of uncertainty in conditions of pandemic increased even more and it became necessary to develop agribusiness to achieve vital indicators of food security. The fact is that the food crisis poses as significant risks as the pandemic itself. Thus, in an open letter of the Food and Agriculture Organization of the United Nations (FAO), "Let COVID19 not become a game of hunger", in which the organization addresses the countries of the world about the need to develop this field.

Border closing due to pandemic has destabilized the food supply chain of the population and posed a great danger that access to food would be severely restricted in many additional countries. The cause of the problem complication is the fact that many countries have applied restrictive export policies. The policy aims to increase access to food at the national level. These 
factors will lead to significant destabilization of the world food market, disruption of food prices and supply chain. The development of agribusiness will be significantly hindered by the change of production parameters in the fields of horticulture and animal husbandry.

Under such production parameters, the self-sufficiency rates of the population with local basic agro-food products are low. Moreover, the production volume of some agro-food products in Georgia is so small that the demand for them is satisfied by a third of most products according to physiological norms. Recently, there has been a growing trend in the agribusiness sector, as well as an increase in the production of some food products, but the growth rates are very small and not enough to substantially improve self-sufficiency indicators.

According to the system of indicators developed by the FAO, several products are of strategic importance for countries, including wheat, corn, potatoes, vegetables, grapes, meat (cattle, pork, sheep and goats, poultry), milk and dairy products and eggs. These products determine the level of food independence of the country and safe provision of population with food. Production of abovementioned food products in Georgia has decreased in the last decade. Thus, the level of local food satisfaction remains low ${ }^{3}$.

The development of the agricultural sector is of special importance for Georgia and the development of local production is still relevant. ${ }^{4}$

The stability of food self-sufficiency is greatly influenced by food prices. The analysis of the data showed that in April 2020, compared to the same period of the previous year, prices on fruits increased by $45 \%$, dairy products by $23 \%$, meat products by $15 \%$, bread products by $8.4 \%$, and the annual inflation rate was $6.9 \%^{5}$. The main effect on the formation of inflation was the change in prices for food and non-alcoholic beverages. Prices for these products increased by $16.1 \%$. Prices also increased for the following subgroups: fruit and grapes by $45.4 \%$, milk, cheese and eggs (23.2\%, sugar, jam and other sweets by $16.9 \%$, meat and meat products - $15 \%$, fish $-14.9 \%$, vegetables and cucurbits- $14.1 \%$, oils and fats $-11.0 \%$, mineral and spring water, soft drinks and natural juices - $10 \%$, coffee, tea and cocoa $-10 \%$, bread and bakery products $-8.4 \%{ }^{6}$.

Analysis of the FAO Food Price Index for the 5 main products of the consumer basket (milk, cereals, vegetable oil, sugar, meat) showed that this figure has been growing continuously for the last few months, as a result of which the price index has reached its highest level in 5 years. Given the constant rise in food prices and inflation in general, the problem of food security is noteworthy.

\footnotetext{
3 Eter Kharaishvili, Badri Gechbaia, Gela Mamuladze, Vegetable market: competitive advantages of Georgian product and competition challenges, Journal Innovative Marketing, Issue \#3. https://businessperspectives.org/journals/innovative-marketing/issue-296/vegetable-market-competitive-advantagesof-georgian-product-and-competition-challenges

${ }^{4}$ Kharaishvili E. (2017) Challenges for sustainable food security in Georgia, XV EAAE Congress in Parma: Towards Sustainable Agri-Food Systems: Balancing between Markets and Society, Parma, Italy, 29 August - 1 September 2017.

${ }^{5}$ Inflation in Georgia, Augugst, 2020, https://www.geostat.ge/media
} 
Ensuring food security is a key issue in any country's economic policy. At the national level, food security is considered as a set of coherent programs, the main goal of which is a stable supply of healthy and harmless food to the population of the country. Food security includes three aspects: quantitative, qualitative and socio-economic, therefore, its evaluation should be carried out within the framework of these aspects. ${ }^{7}$

Quantitative aspect is focused on providing sufficient food, qualitative means providing safe and quality food to the population, while socio-economic means increasing the income of the population to the level that actually provides access to food.

The pandemic has caused some destabilization in the food supply chain, thus limiting access to food in many countries. Considering that countries are pursuing restrictive export policies in the current period, it is clear that the problem is expected to escalate further. In such conditions, the need to increase access to food at the national level becomes urgent. Therefore, clear policy goals for the agri-food sector should be established for the countries, including Georgia, and urgent measures for their implementation should be developed.

Food shortage has been reported in many parts of the world before the pandemic. In South Sudan, for example, the food crisis hit $61 \%$ of the population last year, and the food shortage trend in East Africa and South Asia over the years has remained almost unchanged for decades, and the negative supply-demand balance is expected to deepen.

So, in order to assess food security in Georgia, the self-sufficiency coefficients of basic agrifood products require analysis, as well as the trend of local production, import and export dynamics, and price changes. Based on the analysis of these indicators, it is possible to identify the needs of agribusiness development and elaborate agribusiness models.

It must be kept in mind that Georgia has natural and other types of resource potential and opportunities to develop innovative models of the agri-food sector and agribusiness. The country has capabilities to become an independent country in terms of agri-food production, replace imports with local products and cause development of agribusiness to become one of the important components of economic growth. ${ }^{8}$ However, the data showed that in the current period, local production has not been able to replace imports, the productive efficiency and rates of self-sufficiency of the population with food products are low, the country still faces food challenges. Developing and implementing effective agribusiness models will play an important role in solving these problems.

\footnotetext{
7 Akhaladze $\quad$ Z., Shalamberidze M, Food Security $\quad$ Evaluation issues https://atsu.edu.ge/EJournal/BLSS2015/eJournal/Papers/AkhaladzeZeinab.pdf

${ }^{8}$ Kharaishvili E., Erkomaishvili G., Chavleishvili. Agribusiness Development Strategy in Georgia, - ICEMBIT 2015: 17th International Conference on Economics and Marketing Management, Madrid, Spain, November 12-13, 2015.
} 


\title{
STUDY OF RESPONDENT BEHAVIOR IN CONFLICT SITUATION BY CROSS-TABULATION ANALYSIS
} (SPSS)

\author{
Paresashvili N. G., \\ Phd, Associated Professor, \\ Ivane Javakhishvili Tbilisi State University \\ Tikishvili M. P., \\ Phd, Associated Professor, \\ Ivane Javakhishvili Tbilisi State University \\ Kharadze N., \\ Phd, Associated Professor, \\ Ivane Javakhishvili Tbilisi State University \\ Goletiani K.G., \\ PhD, Professor, \\ Batumi Navigation Teaching University \\ Batumi, Georgia
}

\begin{abstract}
Covid-19 has had a significant impact on people's lives, their work style, tempo, mood and rhythm of life in general. Covid-19 has shifted a significant portion of business around the world into a phase of economic uncertainty (Paresashvili, Tikishvili, \& Edzgveradze, Employees discrimination issues based on the statistical analysis using SPSS (Case of Georgia, Republic of) , 2021) This has led to significant changes in employee behavior related to work and daily activities. In many cases, their behavior leads to different types of conflict, which further complicates the management process of organizations. Most organizations faced quite big challenges, such as financial problems were created, some resources were in short supply. All this intensified the internal competition. Due to these factors, people's behavior and attitudes have changed. Their emotional level increased because of the uncertainty that still continues.
\end{abstract}

Keywords: Conflict situation, working field, working position, respondent's behavior JEL Classification: M12, M51, M54.

\section{Introduction}

As people differ in nature, personality, lifestyle, family circumstances, and other factors, they had different approaches to new realities that had different effects on work behavior. The nature of organizational conflicts has also changed and its management has become more challenging for managers and organizational leaders.

It is inconceivable to discuss discrimination issues without organizational conflicts, on which quite a lot of research has been done. (Paresashvili, Gurbanov, Gechbaia, Goletiani, \& Edzgveradze, 2020). Today, there are rich scientific literature on organizational conflicts conducted by foreign and Georgian researchers, which analyzes a number of issues directly related to conflict 
management. One of them is the topic of career development. (Paresashvili, Giorgobiani, Nikvashvili, Pirtskhalaishvil, \& kharadze, 2019). The most important thing for each individual is career advancement and professional growth, in which issues of managing organizational conflicts are quite important, (Paichadze, Kharadze, Paresashvili, \& Pirtskhalaishvili), because it is quite difficult to focus on work processes in a contradictory environment. M. Puangshiri and $\mathrm{H}$. Kleiner (2001) are discussing the retaliatory discrimination issues in their article "What Is Retaliatory Discrimination at Work?". They highlight the acute problems during working process, especially for workers with disabilities. Also, they discuss about the effects of retaliation and make conclusion that the retaliation always costs more than it is worth since damages in a retaliation claim are usually based on the wages that were lost (Puangshiri \& Kleiner, 2001).

In this article we discuss conflictic situations and respondents approach towards the circumstances according to the working field and position with Cross-tabulation Analysis in SPSS (Statistical Package for the Social Sciences).

We expect, that the working field and position effects on variables: Q31 Respondent's Behavior when Conflict Situation arises and also on Q28 Respondent's approach towards the conflict situation. For this purpose we have formulated the following hypotheses:

H1: Respondent's Behavior in Conflict Situation is difference according the wotking field

H2: The wotking field affects on Respondent's approach towards the conflict situation

H3: Respondent's Behavior in Conflict Situation is difference according the working position

H4: The wotking position affects on Respondent's approach towards the conflict situation

Bellow there are brought categories of these variables: q5 Working field, q8 working position, q31Respondent's Behavior in Conflict Situation and q28 Respondent's approach towards the conflict situation:

1. q5 Working field:

- Public sector

- Private sector

2. q8 working position:

- Managerial

- Non-managerial

3. q31Respondent's Behavior in Conflict Situation:

- I try to prove my truth

- I agree with the opponent

- I do not pay attention to the conflict

- I seek the compromised alternative

- I Ask for help to my counterparts and managers

4. q28 Respondent's approach towards the conflict situation

- Positive

- Neutral

- Negative 
We tested the hypotheses with the cross-stabilization procedure and with chi-square test, which was included in it. As the result of cross-tabulation and chi-square tests we received two tables. The first one shows the distribution of variable frequencies: "Respondent Behavior in Conflict Situation" and "Respondent's approach towards the conflict situation" according to the working field and respondents' working position.

Table 1. krostabullation working field \& Position* Q31Respondent Behavior in Conflict Situation\& Respondent's approach towards the conflict situation

\begin{tabular}{|c|c|c|c|c|c|c|}
\hline & & & \multicolumn{4}{|c|}{ q5 working field } \\
\hline & & & \multicolumn{2}{|c|}{ Public sector } & \multicolumn{2}{|c|}{ Private sector } \\
\hline & & & \multicolumn{2}{|c|}{ q8 working Position } & \multicolumn{2}{|c|}{ q8 working Position } \\
\hline & & & $\begin{array}{l}\text { Manageri } \\
\text { al }\end{array}$ & $\begin{array}{c}\text { Non- } \\
\text { managerial }\end{array}$ & $\begin{array}{c}\text { Manag } \\
\text { erial }\end{array}$ & $\begin{array}{c}\text { Non- } \\
\text { managerial }\end{array}$ \\
\hline \multirow{5}{*}{$\begin{array}{l}\text { Q31Respondent Behavior in } \\
\text { Conflict Situation: }\end{array}$} & I try to prove my truth & $\%$ & $44 \%$ & $44 \%$ & $33 \%$ & $25 \%$ \\
\hline & I agree with the opponent & $\%$ & $0 \%$ & $0 \%$ & $0 \%$ & $0 \%$ \\
\hline & I do not pay attention to the conflict & $\%$ & $0 \%$ & $17 \%$ & $0 \%$ & $5 \%$ \\
\hline & I seek the compromised alternative & $\%$ & $56 \%$ & $34 \%$ & $67 \%$ & $64 \%$ \\
\hline & $\begin{array}{l}\text { I Ask for help to my counterparts and } \\
\text { managers }\end{array}$ & $\%$ & $0 \%$ & $4 \%$ & $0 \%$ & $6 \%$ \\
\hline \multirow{3}{*}{$\begin{array}{l}\text { Q28 Respondent's approach } \\
\text { towards the conflict situation }\end{array}$} & pozitive & $\%$ & $0 \%$ & $0 \%$ & $0 \%$ & $8 \%$ \\
\hline & neutral & $\%$ & $0 \%$ & $28 \%$ & $19 \%$ & $7 \%$ \\
\hline & negative & $\%$ & $0 \%$ & $72 \%$ & $81 \%$ & $84 \%$ \\
\hline
\end{tabular}

Source: Compiled by the authors

For the variable q31 (table 1) the outstanding frequency is occupied by the answer: "I seek compromised alternative" from the both working sectors. Although, the respondents who hold the manager's position in the private sector $-67 \%$ is above the others. The second place is taken by the answer: "I try to prove my truth", The answer is most common in public sector.

q31 The answers to the question "I try to prove my truth" by public sector managers and non-managerial employees are identical. However, the behavior of private sector managers in this regard is more active than the public and private sector employees.

It is noteworthy that the employees of both sectors do not directly or secretly agree with the positions of the opponents. Moreover, they do not properly recognize and pay attention to the conflict situation in the organization. While for $17 \%$ of private employees and $5 \%$ of the private sector, the impact of conflicts on their activities and behavior is significant.

As can be seen from the table, a compromise alternative is being sought in both sectors. In this regard, the activity of private sector employees is higher. In the private sector, in the answer 
- "I am looking for a compromise alternative" is a small difference - $3 \%$. However, it is also worth to mention that the response to the search for a compromise alternative has the highest frequency in the public sector. There is a stark difference between this response of managers and ordinary employees in the public sector, with 56 per cent being managers and $34 \%$ nonmanagers.

The following answer dominates the q31 variable: "Ask for help to my counterparts and managers". As can be seen from the table, managers do not turn to anyone for help. We consider two possible explanations: they do not recognize the competence of others, or they are confident in themselves that they will handle the problem well.

For the variable q28 the attitudes of the respondents here are really different. In the public sector. While $0 \%$ of public sector managers view conflict situations negatively, a fairly large proportion of $81 \%$ of private sector managers view the process as negative, and also maintain a similar position to employees.

The second table (table 2) that involves the results of chi-square results represents whether there is the presence of the connection between the working field and q31, q28, and between the respondents' position and q31, q28.

As it is obvious due to the table2 the working field impacts on both variables: q28 Respondent's approach towards the conflict situation and q31 Respondent Behavior in Conflict Situation variables with maximal statistical significance $(P<0.001)$, However according to the chisquare coefficient there is more impact on variable q28 Respondent's approach towards the conflict situati. These data give us reason to conclude the truth of $\mathbf{H} \mathbf{1}$ and $\mathbf{H} \mathbf{2}$ hypotheses.

We cannot say the same of a working position variable, it has no impact on variable-q28 (because statistical significance is greater than 0.05), but it affects variable - q31 with maximum statistical significance $(P<0.001)$. Therefore, based on the results of the chi-square test, we conclude that the $\mathrm{H} 4$ hypothesis is true, while the third hypothesis is not proven, The working position daoes not effect on variable q28 - Respondent's approach towards the conflict situation, in this case, there are almost adequate responses from managers and non-managers to respondent's approach towards the conflict situation.

Table 2. Rezults of Pearson Chi-Square Tests

\begin{tabular}{|l|l|c|c|}
\hline \multicolumn{2}{|l|}{} & $\begin{array}{c}\text { q8 working } \\
\text { pozition }\end{array}$ & $\begin{array}{c}\text { q5 working } \\
\text { field }\end{array}$ \\
\hline $\begin{array}{l}\text { q28 Respondent's approach towards the } \\
\text { conflict situation }\end{array}$ & Chi-square & 3.617 & 26.707 \\
\cline { 2 - 5 } & df & 2 & 2 \\
\cline { 2 - 4 } & Sig. & $.164^{\mathrm{b}}$ & .000 \\
\hline \multirow{2}{*}{ q31 Respondent Behavior in Conflict Situation } & Chi-square & 20.076 & 46.649 \\
\hline
\end{tabular}




\begin{tabular}{|l|l|l|l|}
\hline & df & 3 & 3 \\
\cline { 2 - 4 } & Sig. & .000 & .000 \\
\hline
\end{tabular}

Source: Compiled by the authors

We created graphs to visualize the relationships between the variables

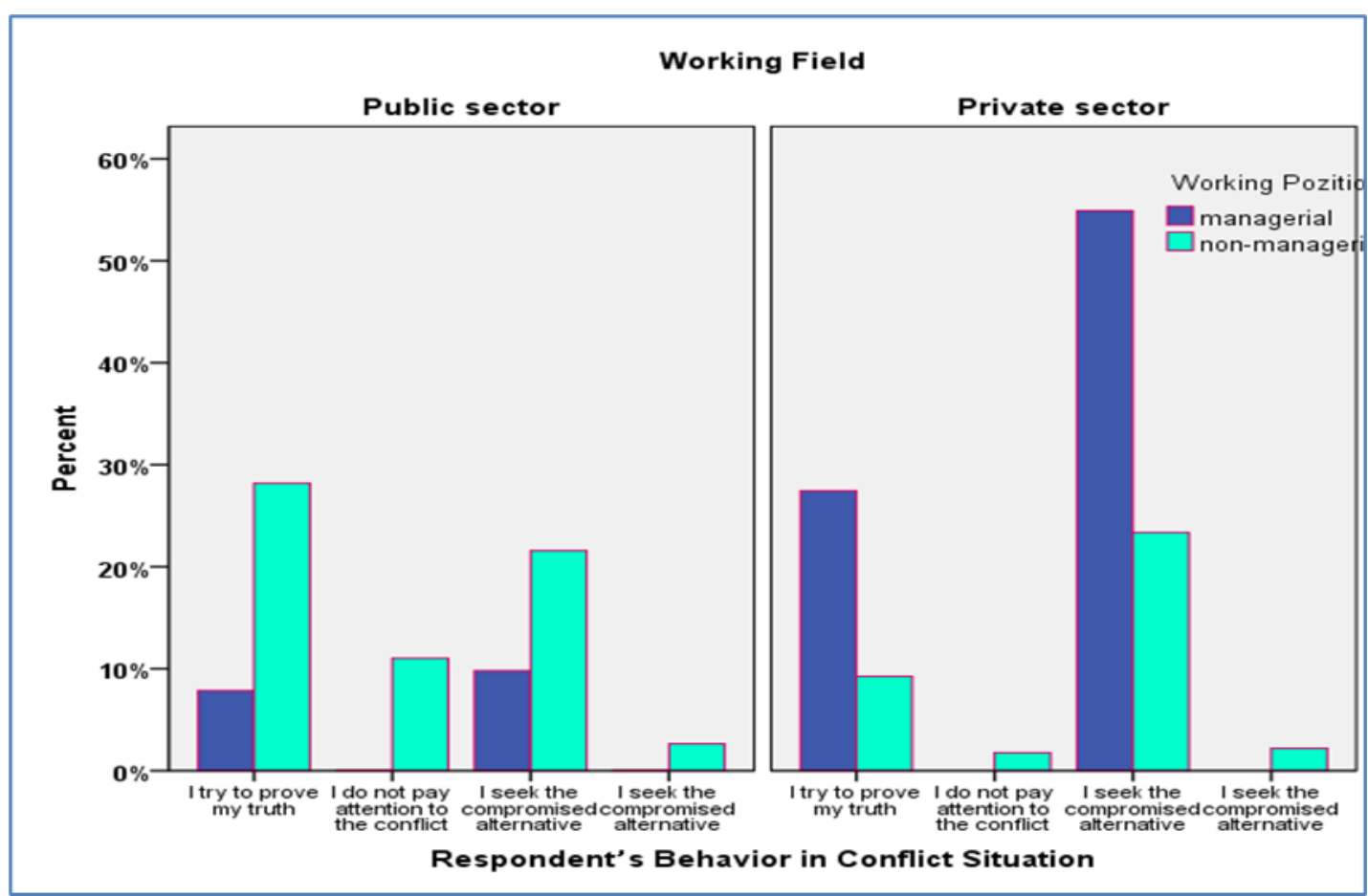

Fig. 1. Respondent's Behavior in conflict situation according to the working field and position

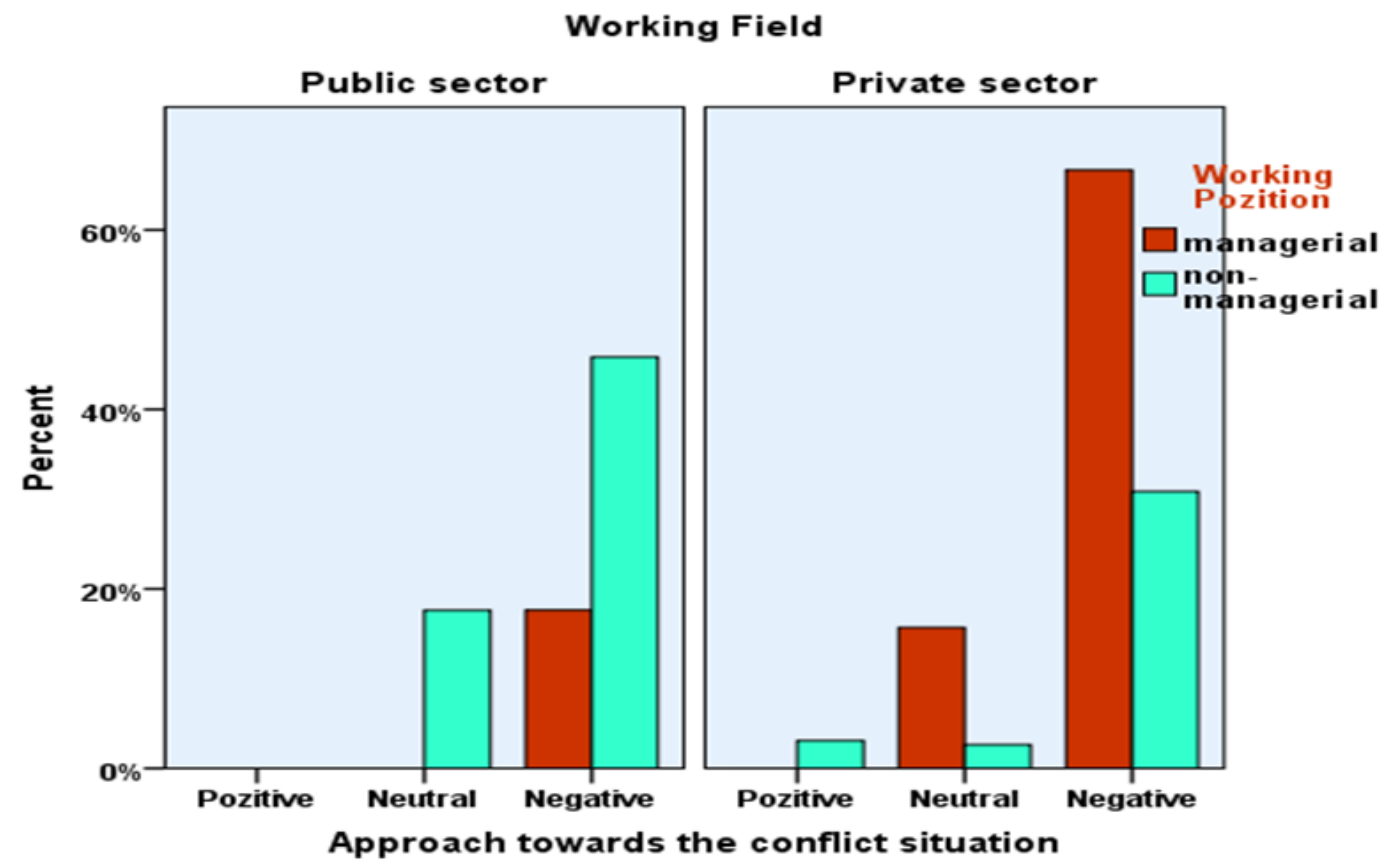

Source: Compiled by the authors

Fig. 2. Respondent's approach towards the conflict situation according to the working field and position 
Conclusions. Every organization has specific style, specific rules, policy and situations which cannot be combine in general rules (Maisuradze T., 2017). So, they should be considered as well. Also, it should not be left beyond attention that stimulation of conflict can be very effective mechanism for organizational development with its constructive outcomes (Gurbanov N., et al, 2021).

In various science publications in some cases we have seen concerns about the possibility of utilizing different governance tools to ensure positive behavior in an organization. However, the reality of today and the high self-awareness of employees indicate that under transparent and fair governance it is really possible to achieve positive employee behavior in the organization. After which we can achieve results that truly prevent dysfunctional conflicts and serve organizational purposes. This will help align the goals of the individuals and the organization.

Therefore, we believe that the theoretical processing of the results of any research and their application will increase the activities of individuals in the organization and even improve the performance of the company as a whole. If employees see that the efforts of managers are aimed at maximizing their talents and ideas, creating a non-conflict environment, then positive behavior and action on their part will be directed to the success of the organization, which will be beneficial on both sides.

It is noteworthy that in the public sector, more attention should be paid to the emergence and settlement of conflict situations, in order to make the environment more comfortable for employees.

\section{REFERENCES}

1. Colquitt J., LePine J., Wesson M., Organizational Behavior: Improving Performance and Commitment in the Workplace), $6^{\text {th }}$ Edition 2019, McGraw-Hill Educatio, ISBN13: 9781259927669

2. Gurbanov N., Paresashvili N., Nadjafova Z., Maisuradze T., Nikvashvili M., Organizational Conflict Management During Covid 19, 2021, 70th International Scientific Conference on Economic and Social Development, proceding

3. Maisuradze T., 2017, Crucial Factors For Better Performance, International Scientific and Practical Conference "WORLD SCIENCE", № 8(24), Vol. 2

4. Maisuradze T., Paresashvili N, 2017, Mechanisms Of Organizational Conflict Resolution In Georgia, Journal of International Economic Research, ISSN 2500-9656, Volume 3, № 1, pg. $75-80$

5. Kharadze, N., Paichadze, N., Paresashvili, N., Pirtskhalaishvili, D. (2019). General Trends of Business Career Management, European Journal of Economics and Business Studies, Vol 5 No 1 (2019): EJES January -April , DOI: http://dx.doi.org/10.26417/ejes.v5i1.p153-177

6. 6. Paichadze, N., Kharadze, N., Paresashvili, N., \& Pirtskhalaishvili, D. (n.d.). General Trends of Business Career Management . European Journal of Economics and Business Studies, Vol 5 No 1 . .pp.153-177 
7. 7. Paresashvili, N., Giorgobiani, M., Nikvashvili, M., Pirtskhalaishvil, D., \& kharadze, N. (2019). Career Management Peculiarities in Educational Institutions. South East European Journal of Economics and Business, 5 (1), 207-224.

8. 8. Paresashvili, N., Gurbanov, N., Gechbaia, b., Goletiani, k., \& Edzgveradze, T. (2020). Paresashvili N., Gurbanov , N., Gechbaia, B., R., Goletiani, K. Significant Issues Of Organizational Conflict Management. 55th International Scientific Conference on Economic and Social Development, (pp. 457-464). Baku.

9. Paresashvili N., Abesadze N.; Kinkladze R., Chitaladze K., Edzgveradze T., Georgian Labour Market during the Coronavirus Pandemic, SHS Web of Conferences 92, 0 (2021) Globalization and its Socio-Economic Consequences 2020,

a. $\quad$ Retrieved 30.04.2021 from https://doi.org/10.1051/shsconf/20219207046

10. Paresashvili N, Okruashvili N., Chitaladze K., 2021, The Need For Cross-Cultural Competencies In A Multicultural Environment, 15th International Technology, Education and Development Conference, INTED2021Proceedings,Pages:99469952https://library.iated.org/publications/INTED2021/start/1425?fbclid=IwAR3WGqdvoZ86Xqe5n EzPo3ZHEij6A2cJGElaDmfNlyPapj50wcQSQwqYP7k

11. Paresashvili N.,Tikishvili M.,Edzgveradze T., Employees discrimination issues based on the statistical analysis using SPSS (Case of Georgia, Republic of), 2021, Access Journal, Volume 2, Issue 2, pp.175-191

a. $\quad$ https://journal.access-bg.org/issue-2-2-

2021?fbclid=IwAR1dzB2tcGbVE8dq5HgSrF-1s-I0-7Q7FTOMLcTYRRmWoy24nBfJm91YOSs

12. Puangshiri M., Kleiner H. (2001), WHAT IS RETALIATORY DISCRIMINATION AT WORK? Equal Opportunities International, Volume 20 № 5/6/7. pp. 37-40 Ricky W. Griffin, Gregory Moorhead, Organizational Behavior, Managing People nad Organizations, 2014, , printsd in Canada, ISBN -IB: 978-1-133-62669-5; ISBN -IB: 1-133-62669-6

13. Schermerhorn, JL. Richard N. Osborrn, Mary Uhl-Bien, James G. Hunt, Organizations Behavior, $13^{\text {th }}$ editional, John R. copyright 2014, printed in the United States of America, ISBN 978-1-118-51737-6 


\section{EQUALITY AND TOLERANCE RELIGIOUS DIVERSITY}

Tchkhonia N.,

Doctor of Education, Associated Professor

Batumi Navigation Teaching University,

Georgia, Batumi

It is generally recognized that the only intellectual education has brought no good to the world. Existing of a complete individual, a full-blown family or society is impossible without emotional education and formation of a value system. The value system is a decisive matter. To begin with, it would be good if we could agree, in particular, what we mean by talking about this issue. If we talk about the attitude towards the world, the feeling of homeland, love, friendship, support or kindness, then it's naturally, neither the educational institution nor the society can do anything more important than that. The debate over values and their definition is ongoing constantly in society. I have the impression that our society is very heterogeneous in terms of the perception of the word "value". The constructions that all of us imagine under these word agreements are very different. It would be good for a large part of society to show some agreement on what value system we recognize as the foundation of our identity and the moral orientation of future generations. What are morals and ethical values? In the concept of "education" extensive meaning of the word includes both education and teaching, but when we use in the narrow sense of this concept, we mean such forms of education as mental, moral, aesthetic, religious ... education.

The first detection of morality is prohibition. Becomig a moral person, being human is related to these prohibitions. It is detected in adat, a taboo. Man is obliged to perform, to obey the authority of the moral tradition, says V. Ramishvili. morality was formed - a set of norms, rules, laws as prohibitions of moral behavior, which distinguish between kindness and evil. You must fulfill the moral requirements of the moral tradition without thinking. (V. Ramishvili: 354)

The first person to try to understand the possibility of human being morality was Socrates. He said that it is completely different when you fulfill a moral norm by the force of tradition and perform a moral requirement consciously because you can not do that. This forced power is not a tradition, but your inner voice. According to Socrates, man should make a free choice of behavior and must know what he is doing in order to be first responsible for his behavior. Being a moral person is a heroism, for that you have to be free and wise.

One must know what is good and what is evil in order to make the right decision. The wise and prudent will not commit evil. Again if we rely on the thought of Socrates, in his view the man should have been right before his own conscience. Behavior can indeed be fair and kind or it may be deemed as convenient. Where should a person have the knowledge of kindness?

Over the years, people have been imposed since childhood that religion and faithare opposed to science, when they complement each other. The source of knowledge is faith.The axioms on which science is based already imply belief. At the same time, a believer is a slave without knowledge, moreover, without knowledge there is no faith, because the man required to 
know what he believes. He who is a believer and a scholar regardless of religion is a friend of God. Every person must strive to ascend the ladder of perfection in order to become a friend of God (Collection of "Grace" 1990 - 2010 I; 36). The teaching on religious morality originates from ancient times. In many successful countries of the world, religious education is considered to be the main task of education. Knowledge shared with faith is impossible without religious education. Researchers have identified several major and controversial issues regarding the teaching of religion in schools. What is meant by religious teaching? How should different religions be taught?

Teaching religion, the history of religion and its connection to civilizations in schools is one of the most important components of perfect knowledge. Getting familiar different religions helps students develop different cultures, respect for minorities, and religious tolerance. Religion as a school subject should be taught as it is essential for getting a general education. A nation needs a person filled with true faith, nurtured by love, willpower, and a sense of responsibility. There are also attempts to make immoral existence the norm in human relationships within us. We must teach adolescents the spiritual perception of events so that they can independently respond appropriately to the challenges of time: "We must first protect the human soul, its psyche and inner nature." (Catholicos - Patriarch Ilia II, 1998-2007; 156).

There remains only one solution, that we should be able to develop immunity to all negativity and immorality in adolescents and young people and create a solid moral foundation for them. We are obliged to take care of the future of the nation if we want to build a developed democratic state with moral grounds. For example, an important aspect of the American norm is the real equality of the religious organization before the state. That is why the existence of state and privileged denominations is accepted in America. The voluntary nature of religious life, the primacy of the society democratic form. In the foreground will emerge the role of social tolerance, charity, which will shift rituals and asceticism in the background. Perspective cultivate personal responsibility and increase the role of the believer in free choice and respect for him.

Therefore the term tolerance, which refers to tolerating a different worldview, lifestyle, behavior and habits. Tolerance does not mean indifference, nor the forced adoption of a different worldview or lifestyle. It means giving others the right to live according to their individual worldview. It includes respect for the free will of the human person, respect for universal rights and not for respecting any particular choice, tolerating the behavior and views of others. A person has the ability to recognize, respect or take into account the other person's beliefs, behaviors, values. To accept a person as he is, the main thing is human values and not his origin or even social status. After all, our nation needs a simple, easy and tolerant citizen, which requires awareness, honesty, thinking, thinking, encouragement, foresight, education, sharing other people's thoughts, searching for a personality and appreciating a person. Only equality, it will be with education or religious belief, can motivate a person to fight against time and space without aggression.

\section{REFERENCES}

1. V. Ramishvili. "Philosophy", Tbilisi;2009; P. $354-355$

2. G. Shervashidze. " "Introduction to the Philosophy of Education", Batumi; P. 150

3. "Grace“ 1990 - 2010 Collection I; Published by Georgian Patriarchate. Tbilisi, 2010, P. 36. 
4. $\quad$ Epistles, words, sermon, book III, Tb, 2008. P 155.

a. Rene Descartes "Discuss the method. Metaphysical meditations" "carpe diem"; Tb, 2010.

5. Livingston Hill Rut, “On Education”, "New York”, 1945; 33. 139.

6. http://www.politscience.ge/index13.html

7. http://www.orthodoxy.ge/metsniereba/tsargvna/1-metsniereba_r

\section{PANDEMICS AND INVESTMENT CLIMATE OF GEORGIA}

Zhozhuashvili N., Associate Professor of Gori State Teaching University

Duruli Ts., Professor of Gori State Teaching University Gori, Georgia

The investment environment is an essential part of a strategy focused on stimulating economic growth and development for each country.

Creating a healthy investment climate and encouraging investment has become a priority for the government of both Georgia and any country under the Covid-19 pandemic.

Before to the pandemic, Georgia had a highly effective local or foreign investment policy. Therefore, in terms of economic freedom, according to the Heritage Foundation (2021), Georgia is in the $12^{\text {th }}$ place out of 180 countries worldwide and ranks $9^{\text {th }}$ place across Europe. In addition, according to the World Bank, Georgia's ease of doing business index is 82.04 , which is the 7th position among 190 countries in the world.

The Covid-19 pandemic has completely changed the world economic processes, both in foreign countries and in Georgia. Clearly, the situation in the world is reflected in the general investment climate. The most important part of foreign direct investment in Georgia belongs to the European Union. Investments from the USA account for $7.8 \%$ of total investments, while investments from China account for 3.2\%. According to data of 2019, the 15 most important investors were the USA, China and Japan. The economic effects of the viral explosion in the existing countries directly spread to Georgia as well.

The trend of declining investment has been a significant threat to the Georgian economy in recent years. Today, these risks are even more urgent. Closing borders and stopping economic activity by countries is slowing down economic growth. According to UNCTAD, the world economy will shrink by $1.5-3 \%$ this year and will be about $\$ 6.3$ trillion US dollars less than last year. According to recent UNO data, the pandemic will lead to a reduction in FDI's by $30-40 \%$ in the world, while according to previous forecasts, this figure did not exceed 5-15\%. 
In this regard, Georgia is no exception and the primary negative economic consequences caused by the pandemic are already visible. According to the preliminary data of investments of the Statistics Service for the first quarter of 2020, there is a sharp decline in the volume of foreign direct investment in Georgia. Specifically, investments in the I quarter of 2020 amounted to 165.4 million US dollars, which is $41.7 \%$ less than in the I quarter of 2019 . The Georgian government should be able to attract foreign investment resources to the country, creating a favorable environment for this.

The existence of conflict regions has a more negative impact on Georgia's investment climate. For every investor, the prerequisite for investing in a country is protection of property rights, stable political situation, favorable tax regulations, cheap and qualified labor force, and stable macroeconomic environment, economic openness of the country, free trade agreements, and low level of corruption for both foreign and local investors.

The terms of the crisis is uncertain at the moment, as well as how the world will be able to deal with it. Georgia-type countries will be significantly dependent on the scale of international assistance they will be able to mobilize in various directions, for which it is vital to define national investment policy and improve the investment environment in the country.

\section{REFERENCES}

1. Covid-19 epoch and investment prospects - Konrad Adenauer Foundation -KAS and EPRC Economic Policy Research Center -2021.

2. Economic Consequences for the World and Georgia - EPRC Economic Policy Research Center - 2021.

3. Investment

Responses

to

COVID-19-

https://www.oecd.org/investment/investment-responses-to-covid-19.htm

4. https://www.worldbank.org/en/home - World Bank

5. https://www.geostat.ge/ka - Geostat 


\title{
INCREASING THE LEVEL OF CORPORATE SOCIAL RESPONSIBILITY IN THE PERIOD OF COVID-19 PANDEMIC
}

\author{
Novomlynets 0.0., \\ Doctor of Technical Sciences, \\ Associate Professor, Rector, \\ Chernihiv Polytechnic National University \\ Chernihiv, Ukraine \\ Verbytska A.V., \\ PhD in Public Administration, \\ Head of the Department of Marketing, \\ $P R$-Technologies and Logistics, \\ Chernihiv Polytechnic National University \\ Chernihiv, Ukraine
}

In the context of the pandemic, an increasing number of citizens need support both from the state and from business companies engaged in socially responsible activities. Enterprises, realizing their responsibility to the community, began to create new areas of activity related to corporate social responsibility in order to smooth out the negative impact of the pandemic on people's lives. Unfortunately, the increase in the level of corporate social responsibility in the context of the pandemic has been uneven. For example, some companies specializing in the sale of computer games, table games and books did not provide support to the population, taking advantage of favourable market conditions in order to maximize profits in a pandemic, when the demand for their goods increased significantly. Moreover, many companies that, for PR purposes, make official statements that they have increased their level of corporate social responsibility, not only did not provide support to the population and their clients, but also worsened their financial situation. There are also companies that believe that the pandemic is a "period of uncertainty", so spending any amount of funds on social projects is unwise, because this can cause companies to go bankrupt in the long term. Because of this, stakeholders believe, that the level of corporate social responsibility of enterprises began to decline sharply in the period of pandemic.

The COVID-19 pandemic has adjusted the corporate social responsibility of companies and changed the priorities and plans of their programs. The motives of companies' aspirations to carry out socially oriented activities are extremely different. Some of the companies have the desire to be branded as a philanthropist and thereby improve the company's image. The other businesses have the intentions to keep up with companies that are already providing support to the population during a pandemic, and not to be seen as indifferent against the background of competitors.

Businesses have engaged in a wide range of corporate social responsibility actions during the pandemic, motivated by utilitarianism and deontological factors in response to the needs of internal and external stakeholders [2]. As stated by He H. \& Harris L., Covid-19 opens a new era of 
corporate social responsibility development and pandemic offers new possibilities for business to be actively engaged in various social responsible initiatives [1].

The companies, which provide support to the population in a pandemic firstly and submit information about their activities to the media, got the greatest benefit from socially responsible behaviour. The traditional ways of communicating with the consumers and other stakeholders during the pandemic lost their relevance, and the only available tool that strengthened the brand's reputation was the actions of enterprises to combat the virus. Corporate social responsibility initiatives in the Covid-19 period transformed traditional PR into "responsible communications", strengthen the social brand image and build trusting relationships with customers, suppliers, local residents and investors. While helping the population through the programs implemented by enterprises in the field of corporate social responsibility, the companies have increased their authority and built mutually beneficial relationships between those who provide assistance and between those who receive it. As many companies receive significant benefits from the implementation of their programs during a pandemic, they have a great incentive not to stop these programs and launch new ones. There is a possibility that the level of corporate social responsibility throughout the entire period of the pandemic will grow.

Conclusions. Current level of corporate social responsibility is at an average level, but it is growing rapidly. Nowadays there are no effective models of corporate social responsibility management. Realizing the importance of supportive actions for people who fell into financial difficulties during the pandemic and became part of vulnerable groups, responsible companies implement socially oriented projects. They also restore their large planned projects carried out within the framework of corporate social responsibility: support for the environment, local communities, implementation of projects in the field of sustainable development. Business companies demonstrate their level of flexibility to make decisions related to their activities in the direction of corporate social responsibility.

\section{REFERENCES}

1. He H., Harris L. The impact of Covid-19 pandemic on corporate social responsibility and marketing philosophy. Journal of business research. 2020. № 116. P. 176-182.

2. Manuel T., Herron T. L. An ethical perspective of business CSR and the COVID-19 pandemic. Society and Business Review. 2020. https://doi.org/10.1108/sbr-06-2020-0086. 


\section{FEATURES OF FORMATION OF TIME MANAGEMENT SYSTEM AT THE ENTERPRISE}

Ostryanina S.V., Associate Professor,

Grebenik I.P., Student, University of UCU "Poltava University of Economics and Trade",Ukraine

The introduction of a time management system involves the formation of employees' time competence related to the issues of time awareness, emotional experience of time and organization of time of professional activity, which in combination provides emotional stability, stress resistance, self-organization.

Temporal competence involves the ability to rationally plan and use time, adequately assess the necessary time, to develop a program to achieve the goal in a certain time space. In addition, it is an important condition for a person's value attitude to the time budget and integration into social groups.

Resource-time component of competence means adequacy of time perception, mastery of time planning skills, ability to rationally redistribute time priorities and limits of interpersonal communication, adhere to the principles of time management, such as: system, measurability, materiality, flexibility, priority, timeliness, integrity, and controllability, alternative.

In communication, temporal competence determines the adequacy of the subjective assessment of time and time space of interpersonal interaction, the ability to optimal interaction taking into account the time limits of communication, empathy in expanding or removing the time limits of communicative control.

In our opinion, time management can be successfully combined with team building technologies, as one of the criteria for effective functioning of working groups and teams is the effective use of working time due to the effective influence of formal and informal leaders, compliance with team norms, and coordinated interaction of participants. psychological compatibility and professionalism.

Social time management is devoted to interpersonal relations and requires sufficient knowledge of strategic and operational management, organizational structure, features of production processes. The system of corporate time management is represented by: time management of the enterprise - focused on the formation of effective interaction between departments and officials with the widespread use of information technology; time management of separate divisions - provides formation of uniform algorithm of work for employees of one or several divisions performing identical duties; individual time management of leading specialists is an individual time management of the head and the person. This direction is now the most developed and effective in terms of practical use.

Therefore, to ensure the effectiveness of time management in the time management system at the enterprise, it is advisable to: clearly define the priority of tasks; reduce losses of working time; skillfully delegate authority; improve their communication skills; correctly and 
timely train staff in self-management technologies; monitor working time management processes.

\section{ON NECESSITY OF GEORGIA'S INVOLVEMENT IN THE EUROPEAN TRANSPORT SPACE}

Khvedelidze P.G., PhD, Professor,

Batumi Navigation Teaching University

Batumi, Georgia

Due to its strategically important geographical location, Georgia has a key transit function throughout the Caucasus and beyond. Thus, the improvement of transport infrastructure and vehicles is a necessary precondition for the economic and social development of the country. That is why it is very important to study transport-related directives in the Association Agreement with the European Union and to step-by-step introduce them. Involvement in EU transport and communication networks will open up completely new opportunities for Georgian citizens and businesses and contribute to the country's economic growth: Georgia is becoming one of the important hubs connecting two major markets - the transport corridor of Europe and Asia.

The Association Agreement with the European Union first of all envisages the modernization of transport and introduction of European standards. The widely spread notion that Georgia will have to fulfill these obligations immediately is wrong. Association Agreement is followed by annexes with specific EU legal acts and timeframes for getting Georgian laws closer to them. Thus, harmonization of Georgian laws with EU regulations will happen in accordance with agreed timeframes and, most importantly, stage by stage. Association Agreement mentions four key spheres of transportation - cars, railroad, maritime and air - envisioning harmonization of the existing Georgian legislation with the European one and creation of mechanisms for its implementation.

It should be noted that the most of EU Regulations deal with motor vehicles, namely with the improvement of existing legislation and regulations in the field of freight and passenger transportation (more than 9 people). Digital tachographs are already being introduced in Georgia and it can be said that certain requirements of the Association Agreement for auto-trucks have already been met. According to EU legislation, use of digital tachographs is obligatory for the cars transporting more than 3.5 tons of cargo, or at least 9 persons.

This control mechanism shows the car's speed and working and resting hours of the driver. Georgia is implementing overland transport safety project, which envisages introduction of transport and infrastructure safety standards and regulations. The project aims to help Georgia and other TRACECA countries in harmonization of relevant laws, international procedures and EU legislation.

Improvement of safety regulations in transportation field and approximation with European legislation will promote strengthening organizations responsible for the field of 
transport, improving knowledge and skills of the people employed in this filed. It is important to raise awareness of citizens, media, and business representatives on these issues that will promote gradual integration with Europe, modernization of our transportation system, protection of the rights of every subject participating in the road transportation: disabled persons, pedestrians and the children included. Furthermore, the implementation of the EU standards in road, railway, aviation and sea transportation will allow Georgia to participate in projects funded by the EU, while acting as the country receiving its intellectual and financial resources. The Association Agreement requires the fulfillment of four key provisions of European transport legislation, such as: technical, safety, social and financial conditions. The main requirement in the implementation of the technical requirements envisages installation and usage of speed-limitation devices on passenger and cargo automobile transportation ( 9 and more individuals).

It is a well-known fact that the violation of speed limits is a major reason for road incidents, which is confirmed by official statistics. Furthermore, unfortunately the large bulk of fatalities and injuries of road incidents come from cargo and passenger transportation. Every year, Georgia loses hundreds of millions GEL as a result of road incidents.

According to Association Agreement with EU, regulations, related to speed-limitation devices for passenger cars registered in Georgia should be implemented within 6 years, and for vehicles participating in international transportation and those, registered for the first time within 2 years.

Integration of Georgia into the European transport space will raise living standards of Georgian citizens, increase economic opportunities and improve public health.

\section{REFERENCES}

1. Chikovani E., The main directions of improving freight transportation in Georgia. Tbilisi, 2020;

2. Tsanava N., Papiashvili M. Georgia's transport corridor and its economic efficiency. Tbilisi, 2019;

3. Navadze N., Kartvelishvili V., Gorshkov T. Passenger-road transportation, Tbilisi, 2009, p. 137;

4. Gotolandia B., Economic problems of the development of the transport corridor of Georgia and the directions of their solution. Tbilisi, 2011; 


\section{EMPLOYMENT TRANSFORMATION IN CONDITIONS OF DIGITALIZATION}

Ushenko N.V., Doctor of Economics, Professor, Head of the Department of Economics and Business Technology Semenova D.O., Ph.D. in Economics, Associate Professor, Tereshchenko E.Y., Ph.D. in Economics, Associate Professor, National Aviation University Kyiv, Ukraine

The term "digitalization" is firmly entrenched in the life of society and is often used in scientific publications and on discussion platforms, where its advantages and disadvantages are discussed. Today's realities dictate new approaches to the labor market conjuncture. One of the main threats, on the one hand, is the lack of professional personnel and jobs, and on the other hand, the lack of demand for the able-bodied population in the process of transforming the information systems of the economy into a digital environment.

The employment is one of the important areas of society. It affects the interests of the overwhelming majority of the population and serves as the main source for the formation of its income base. In the conditions of the uncertainty of the modern world, due to the influence of global trends (digitalization of the economy, automation and robotization of production, aging of the population, etc.), a deformation of the traditional employment model for the current period is taking place. New forms of labor relations are emerging, opportunities for remote work and selfemployment are expanding, the nature of labor activity is changing, ideas about social guarantees are blurring, etc.

In advanced economies, technological change has already displaced some groups of the labor force as a result of global competition. In emerging markets, automation is a growing threat to low-skilled workers [1].

In a Delphi study by the Bertelsmann Foundation, experts expect unemployment to rise steadily in both developed and developing countries, as potential productivity gains catalyze such changes in manufacturing processes. [2].

In order to quickly navigate in the period of changing of scientific and technological transformations and turn threats into a competitive advantage, it is necessary today to prepare a high-quality workforce to facilitate the rapid introduction of new technologies into the country's economy. One of the options is the transformation of the population's employment, which determines the prospects for maintaining the models of labor relations that are customary for the current period. In the scientific literature, these aspects are revealed through the prism of 
intersectoral distribution of the labor force, labor organization, the relationship between the employee and the employer, and public institutions (Fig. 1).

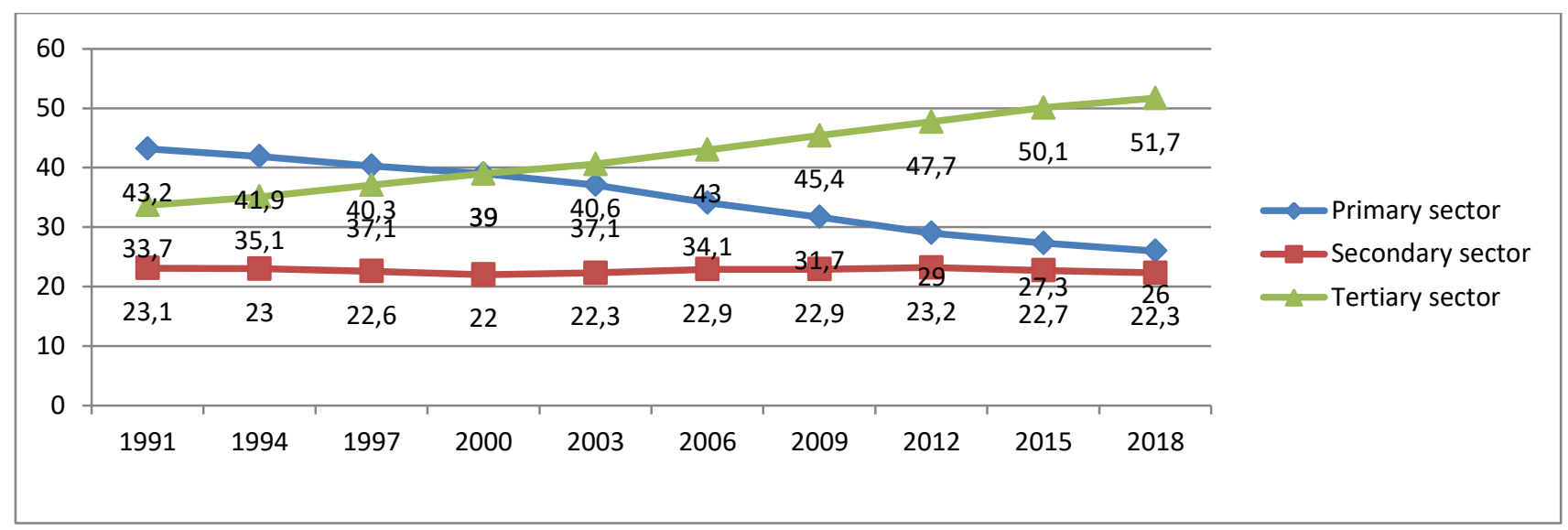

Fig. 1. Sectoral distribution of workers in the world, \%

Source: World Bank Open Data (https://data.worldbank.org)

Market analysis showed the concentration of most of the labor force in the tertiary sector of the economy, which indicates a shift from material production to intangible assets. That is, quantitative changes are transformed into qualitative transformations in the field of employment.

The accelerated pace of innovation poses new challenges for society: to intensify the search for solutions to use the opening opportunities for creating new jobs and understand the evolving trend and develop a system that can improve the abilities of each individual and prepare workers with the appropriate skills. At the same time, the economy must have appropriate flexibility and be equipped with support mechanisms that allow companies, human resources and society as a whole to quickly and successfully adapt to faster and deeper changes taking place in a rapidly changing world [3].

Thus, modern trends dictate the need to create and implement the total digitalization, which opens up additional opportunities for business that can radically reformat it, increasing labor productivity with a significant reduction in production and distribution costs.

In this regard, it is relevant to stimulate the emergence of new segments of the economy and the development of advanced technologies that stimulate the demand for specialists who meet the latest digitalization requirements: cognitive skills; socio-behavioral skills; digital skills.

Conclusions. The modern labor market is undergoing deep modernization processes. The introduction of digitalization has two sides: new opportunities and new risks, and the labor market is especially sensitive to them. Stimulating the emergence of new segments of the economy and the development of high-tech, innovative industries can intensify the demand for specialists who meet the latest digitalization requirements, and innovative changes in the education and retraining system can reproduce the corresponding human potential.

\section{REFERENCES}

1. Popov A.V. Conceptual framework of studying the process of employment transformation. Teoreticheskaia ekonomika, 2019, no. 6, pp. 18-26. 
2. The Future of Jobs World Economic Forum. Weforum. Available at: http://www3.weforum.org/docs/WEF_Future_of_Jobs.pdf.

3. Shvydanenko H., Tepliuk M. Digitalization is a modern direction of development of innovative entrepreneurship. Available at: https://core.ac.uk/download/pdf/197269051.pdf

\section{COACHING AS AN INTEGRAL PART OF ON-THE-JOB BUSINESS EDUCATION}

Riashchenko V., Dr.oec., prof.

ISMA University of Applied Sciences

Riga, Latvia

Lubenchenko O.,

DSc in Economics, Professor, Head of National enter for Accounting and Audit, National Academy of

Statistics, Accounting and Audit, Kyiv, Ukraine

An organization of any type has the main task - to use the potential of its personnel as efficiently as possible. The system of effective work with personnel assumes that one of the most important factors is the disclosure of a person's potential to maximize his effectiveness. Bodo Schaeffer, a leading financial advisor in Europe, says: In the information age, the best and most profitable investment is thoughts, ideas, innovations, excitement, passion! (1, p. 68).

The actual question is: How can a manager get from his employees the maximum involvement in the workplace? It is no secret that, on the one hand, it is quite difficult to find highly professional personnel, on the other hand, the requirements of employees to the employer and wages are inadequately high. Trying to reconcile the contradictions that have arisen, modern organizations pay more and more attention to training: they conduct training, organize special training programs, etc. But here, too, some contradiction arises: learning and work sometimes compete with each other, which is a limiting factor. Question: To what extent is training acceptable and sufficient? And when does the point at which learning interferes with the production process comes? Consequently, it is now necessary to use such specific methods that can enhance training, increase its effectiveness and, at the same time, create the most attractive working environment for staff. An environment in which enthusiasm and creativity in the workplace are possible. For most production tasks, the personnel has enough knowledge, skills, and abilities to cope with them. However, often an employee cannot realize his abilities in an environment where "the level of anxiety is high and the level of approval is low" (7, p. 14). It is in such ambiguous conditions that coaching comes to the rescue. 
Conclusion. A manager who uses coaching as a management style acts as a mentor for his subordinates, who trains and develops his employees on the job, which allows them to quickly integrate into the company's business processes and increases their professional and personal efficiency. Thus, coaching staff contributes to the effectiveness of the organization. Coaches of the first persons of the company are consultants and partners because the emotional contribution of coaches to the work of the company and the achievement of its success corresponds to the contribution of the very top officials of the companies their clients. This is probably why the CEOs of tomorrow will choose to mentor rather than control.

\section{REFERENCES}

1. Peter Bluckert (2005) The similarities and differences between coaching and therapy, Industrial and Commercial Training, Volume 37, Issue 2, pp 91-96.

2. Peter Bluckert (2006) Psychological Dimensions of Executive Coaching. Open University Press.

3. David Clutterbuck (2007) Coaching the team at work. Nicholas Brealey International.

4. David Clutterbuck (2013) Powerful Questions for Coaches and Mentors: a practical guide for coaches and mentors. Wordscape.

5. Elaine Cox, Tatiana Bachkirova and David Clutterbuck (eds) (2014) The Complete Handbook of Coaching, 2nd edition. Sage. 


\section{IMPACT OF COVID 19 ON SMES MANAGEMENT IN GEORGIA}

Mushkudiani Z.

Doctor of Business Administration

Associate Professor of Batumi Navigation Teaching University

Tsilosani A.

PhD student,

Batumi Shota Rustaveli State University

Batumi Georgia

Due to the negative impact of COVID-19 pandemic and in a fear of introduction of forced restrictions amid the worsening economic crisis, all governments around the world are taking unprecedented measures to support economic and business activities and maintain jobs. COVID19 is a serious challenge and poses a significant threat to both the world and Georgian economies. In just one year, the virus became a global pandemic, which had a negative impact on the world economy, and the scale and extent of the final impact remains unknown. The impact this virus may assert on the global economy depends on the trend of the virus spreading, the effectiveness of crisis management by countries, social responsibility and the spread and effectiveness of the vaccine already created.

As mentioned above, the COVID-19 pandemic has dealt a heavy blow to the world economy, and it should be noted that globally, the main actors in economic life are not large corporations, but small and medium enterprises, which account for $90 \%$ of the total number of companies, providing $70 \%$ of jobs, and make up $50 \%$ of the world GDP.

The role of small and medium-sized enterprises in the global economy is recognized at the highest level, as evidenced by UN General Assembly Resolution 2017, which declared June 27 as a Day of Micro, Small and Medium Enterprises ${ }^{9}$, and it is aimed to raise public awareness on the contribution of small and medium to the global economy and provision of sustainable development. As well as raising recognition and awareness in developing countries about the need of increase investment in small and medium enterprises.

As the UN has noted, small and medium enterprises may be very adaptable to the changes in the world, although this feature makes them extremely vulnerable to the negative impact of the economic environment, primarily due to insufficient financial sustainability ${ }^{10}$.

Thus, support for small and medium enterprises is not only in the high light of public policy, but also takes a special place in the discussion of the results of the fight against COVID-19.

The relevance of the topic is evidenced by the developments in the world over the recent year, related to the COVID-19 pandemic, which radically changed the world economic situation and which put humanity and the world's leading countries and their economies in front of a

\footnotetext{
${ }^{9}$ (United Nations, 2020)

${ }^{10}$ (UN Global Compact, 2020)
} 
completely new reality. It is especially relevant for those vulnerable segments of the economy, such as small and medium enterprises, which have faced significant challenges due to the current situation and the various types of restrictions imposed.

The aim of research. The aim of this paper is to describe the economic situation caused by the COVID-19 pandemic in small and medium enterprises in the world and in Georgia, and to observe the current events and the development of related processes. The aim of the research is to describe the situation of small and medium in the world and in Georgia during the pandemic, and to identify the problems that can be avoided or alleviated by small and medium enterprises with the involvement of state and on their own.

Subject of research. The subject of this research is to study the situation of small and medium enterprises in the world and in Georgia, to identify factual difficulties, to find ways to solve existing problems, to analyze the best practices in the world and to avoid or minimize potential risks.

Research Methodology. Complex methods of obtaining information were used to achieve the objectives of the research. Bibliographic research was used to extract, sort and analyze secondary data. The theoretical basis of the research is the existing literature on given subject: scientific papers, studies, publications, articles in periodicals, data retrieved from the Internet.

\section{Conclusion}

From December 2019 to December 2020, world developments related to the new coronavirus pandemic clearly showed that the world was not ready for such a challenge, and even advanced countries with robust economy could not withstand the economic pressures caused by the global shutdown and breaks in supply chain. Particularly vulnerable in this situation were small and medium enterprises, most of which received significant blows that were often manifested in the cessation of production, temporary suspension, dismissal of employees and change of core business.

Although small and medium enterprises are quite "flexible" and can respond quickly to external factors, they still remain vulnerable entities that cannot overcome the crisis period on their own and require active involvement and assistance from the state. Due to the fact that in the world as well as in Georgia, a significant share of the economy falls on small and medium enterprises and an even more significant share on the number of employees, delays in provision of state aid to enterprises and making savings on them, can cause significant losses and recession for the country's economy.

In addition to due-time financial support from the state to small and medium enterprises, in our opinion professional and technical support is also required, which should include the involvement of the companies themselves and development of crisis management, risk assessment and business continuity plan by them. In this regard, the state should provide all small and medium enterprises with all the necessary information and materials, which will raise the awareness and recognition of these enterprises, and it will help them act expeditiously and in agreement with the state in tandem, which will significantly ease the working process for both 
parties, minimize uncertainties, and actions will be coordinated as much as possible. Achievement of this will be relatively easy in Georgia, as certain preconditions and basic elements for the management of these processes already exist in the country, such as clear classification of small and medium enterprises, as well as definition of main activities of enterprises by NACE codes, and access of all registered tax-payers to the Revenue Service web portal, where similar types of information are gathered and through which, depending on the field of activity and specifics, it is possible to establish communication between the enterprise and the state. In addition to the above, given that small and medium enterprises do not have enough financial, material and technical and human resources to make digitalization of services and create Internet platforms individually and on their own, it would be advantageous if the state also provides creation of unified space for these enterprises so that they do not suspend their activities and continue activities and provision of services to their customers via the Internet.

\section{REFERENCES}

1. Z. Mushkudiani, B. Gechbaia., I. Gigauri, E. Gulua, Global, economic and technological trends in human resource management development. https://journal.access-bg.org/issue-1-12020/global-economic-technological-trends-in-human-resource, 2020;

2. Z. Mushkudiani, B. Gechbaia., Facing the Global Competitiveness Challenge and Quality of Business Freedom in Georgia. European Journal of Economic Studies, 8(2) http://www.ejournal2.com/ru/archive.html?number=2019-12-01-14:32:36\&journal=24, 2019

3. United Nations, "Micro-, Small and Medium-sized Enterprises" 2020

4. UN Global Compact, "Helping Small Businesses Survive COVID-19" 2020

5. The balance small business, "What Are SMEs?," 2020

6. Eurostat, "The EU in the world," 2020.

7. IMF Blog, "Limiting the Economic Fallout of the Coronavirus with Large Targeted Policies", 2020

8. Organisation for Economic Co-operation and Development, "OECD Policy Responses to Coronavirus (COVID-19)", 2020.

9. Organisation for Economic Co-operation and Development, "OECD Policy Responses to Coronavirus (COVID-19)", 2020.

10. PriceWaterhouseCoopers Georgia, "Georgian companies face the challenge of the covid-19 pandemic," 2020.

11. World Trade Organization, 2020;

12. U.S. Chamber of Commerce, 2020;

13. International Monetary Fund, "Special Series on COVID-19", 2020.

14. International Monetary Fund, "Policy Responses to COVID-19", 2020. 


\title{
METHODICAL APPROACH TO THE CHOICE OF THE SHIPBUILDING COMPANY RESTRUCTURING VARIANT
}

\author{
lefimova G., \\ Doctor of Economic Science/ Professor of NUOS \\ Labartkava A., \\ Candidate of Technical Science/ Professor of NUOS; \\ Pashchenko O., \\ Candidate of Economic Science / Associate Professor \\ Admiral Makarov National University of Shipbuilding (NUOS)
}

The issues of the resources use optimizing aimed at a shipbuilding company restructuring are considered, which the main prerequisite for its effectiveness. The aim of this study is to develop a methodical approach to substantiation of the of the variant of the shipbuilding company restructuring on the basis of optimization-simulation model of its value estimation, which will take into account the algorithmically set conditions regarding the financing scheme, the type of restructuring, technological and economic relations in the system. The task of deciding on the shipbuilding company restructuring and the choice of a specific restructuring project refers to the optimization tasks of long-term planning. The limitations of the mathematical model are the company resources, which are allocated for restructuring. The main optimization criteria are maximizing net present value or minimizing the restructuring cost. The generated optimization model is designed to assess the amount of attracting for restructuring own and borrowed funds. Simulation model provides the cash flows construction. Restrictions on ensuring financial realization reflects the cash flow balance for all activities, which connects the optimization model with the simulation model. The problem solution is achieved on the basis of an interrelated optimization, simulation models and procedures set for the formation, selection and approval of management decisions.

\section{REFERENCES}

1. lefimova, Ganna V. (2014) Optimization modeling of shipbuilding enterprise restructuring efficiency [Optymizatsiyne modelyuvannya efektyvnosti restrukturyzatsiyi sudnobudivnoho pidpryyemstva]. Business Inform 3:109-113. URL: https://www.businessinform.net/export_pdf/business-inform-2014-3_0-pages-109_113.pdf - in Ukrainian

2. lefimova, Ganna V., Labartkava, Andriy V. (2015) Integration as a strategy for restructuring shipbuilding enterprises [Integratsiya kak strategiya restrukturizatsii sudostroitel'nykh predpriyatiy]. Modern management: problems, hypotheses, researches: proceeding of material. Batumi, 2015: 45-48. - in Russian

3. lefimova, Ganna V., \& Rogov, Viycheslav G. (2019) Adaptation of the shipbuilding enterprise to changes in the incentives for its development [Adaptatsiya sudnobudivnoho 
pidpryyemstva do zmin stymuliv yoho rozvytku]. Management and Entrepreneurship in Ukraine: Stages of Formation and Problems of Development 1(1): 92-105. DOI: https://doi.org/10.23939/smeu2019.01.092 - in Ukrainian

4. Burkinskyi, B. V., Laiko, O., \& Losyev, M. (2018) Realization of sustainable development aims for industry and innovations on glocalization principles. Economic innovations, 20 (4 (69)), 722. DOI: https://doi.org/10.31520/ei.2018.20.4(69).7-22

5. Imbalances in the shipbuilding industry and assessment of policy responses (2017). URL: https://www.oecd.org/industry/ind/Imbalances_Shipbuilding_Industry.pdf

6. Solli-Sæther, Hans \& Karlsen, Jan. (2012) Knowledge transfer in shipbuilding projects: A study of supporting mechanisms. International Journal of Project Organisation and Management. 4(3):256-271. DOI:10.1504/IJPOM.2012.048224

7. Grebennik I. V., Chernaia O.S., Makarova E.E. (2018) Optimization of linear functions on the set of cyclic permutations with linear constraints [Optimizatsiya lineynykh funktsiy na mnozhestve tsiklicheskikh perestanovok s lineynymi ogranicheniyami]. Control, navigation and communication systems, Issue 3(49): 67-72 DOI: 10.26906/SUNZ.2018.3.067 - in Russian

8. Martine van den Boomen, Pieter L. van den Berg \& A. Rogier M. Wolfert (2019) A dynamic programming approach for economic optimisation of lifetime-extending maintenance, renovation, and replacement of public infrastructure assets under differential inflation. Structure and Infrastructure Engineering 2019, Vol. 15, No. 2, 193-205 DOI: https://doi.org/10.1080/15732479.2018.1504803

9. Burkov V., Shchepkin A., Irikov V., Kondratiev V. (2019) Methodology and Technology of Control Systems Development. In: Kravets A. (eds) Big Data-driven World: Legislation Issues and Control Technologies. Studies in Systems, Decision and Control, vol 181. Springer, Cham. https://doi.org/10.1007/978-3-030-01358-5_2 


\section{MANAGEMENT OF THE DEVELOPMENT OF THE MARITIME TRANSPORT POTENTIAL OF UKRAINE}

Hryshyna L.

PhD Economics, professor

Hryshyna N.

PhD in Economics, National University of Shipbuilding named after Admiral Makarov, Mykolaiv,

Ukraine

УПРАВЛІННЯ РОЗВИТКОМ МОРСЬКОГО ТРАНСПОРТНОГО ПОТЕНЦІАЛУ УКРАЇНИ

Гришина Л.о.

к.е.н., доцент

Гришина Н.В.

к.е.н., доцент

Національний університет кораблебудування

імені адмірала Макарова

Миколаїв, Україна

В складних трансформаційних умовах економіки України одним із важливих завдань сталого розвитку країни є пошук шляхів відновлення та використання стратегічних ресурсів базових видів економічної діяльності, серед яких важливою являється транспортна система. Являючись одним із структурних елементів транспортної системи України, морський транспорт внаслідок дії деструктивних факторів зовнішнього і внутрішнього впливу протягом останнього десятиріччя демонструє його невідповідність зростаючим потребам у перевезенні вантажів, вимогам європейських стандартів якості надання транспортних послуг, зокрема. При тому, що саме морські перевезення, як найбільш ефективний спосіб доставки вантажів внаслідок низької її собівартості та можливостей вирішувати проблеми перевезення великогабаритних вантажів, виступають одним із найбільш привабливих складових транспортної системи. Тому актуалізуються завдання удосконалення системи управління розвитком морського транспортного потенціалу відповідно до сучасних вимог реформування транспортного комплексу України та світової транспортної системи в цілому.

Дослідження світового досвіду функціонування транспортних систем показує, що більшість морських держав приділяє багато уваги використанню і розвитку потенціалу морського транспорту, обсяги перевезення вантажів яким зростають з кожним роком. Так, морські перевезення вантажів у 2015 р. у Німеччині становили більше 300 млн.тон, у Китаї 213 млн.тон, у Великобританії - 98 млн.тон. Нажаль, Україна в цих показниках значно програє не тільки європейським країнам, а і Росії, де цей показник становить 19 млн.тон. Слід відзначити, що в Україні за попередні п'ять років спостерігається значне зменшення обсягів перевезення вантажів морським транспортом. У 2019 р. порівняно з 2010 р. вантажооборот морського транспорту скоротився на 63,7 млрд.ткм або на 15,2\%, а його питома вага у перевезенні вантажів зменшилася майже на третину (34\%). В структурі транспортного комплексу України у 2019 р. частка морського транспорту в середній чисельності працівників 
становила 0,4\% (в 2010р.-1,2\%), в експорті транспортних послуг - 10,4\% (в 2010p.-15,6\%) (табл.1) [4].

Табл. 1. Основні показники використання потенціалу морського транспорту, як складової транспортної системи України

\begin{tabular}{|c|c|c|c|c|c|c|}
\hline \multirow{2}{*}{ Показник } & \multicolumn{6}{|c|}{ Роки } \\
\hline & 2010 & 2015 & 2016 & 2017 & 2018 & 2019 \\
\hline $\begin{array}{l}\text { Вантажооборот, всього, } \\
\text { млрд.ткм, у т.ч. } \\
\text { - морський транспорт }\end{array}$ & $\begin{array}{c}418,7 \\
3,6\end{array}$ & $\begin{array}{c}334,7 \\
3,9\end{array}$ & $\begin{array}{c}344,2 \\
2,5\end{array}$ & $\begin{array}{c}364,2 \\
2,9\end{array}$ & $\begin{array}{c}361,3 \\
1,8\end{array}$ & $\begin{array}{c}355,0 \\
1,8\end{array}$ \\
\hline $\begin{array}{l}\text { Капітальні інвестиції, млрд. } \\
\text { грн. } \\
\text {-у т.ч. водний транспорт }\end{array}$ & $\begin{array}{l}19,6 \\
0,18\end{array}$ & $\begin{array}{l}18,7 \\
0,30\end{array}$ & $\begin{array}{l}25,1 \\
0,24\end{array}$ & $\begin{array}{l}37,9 \\
0,25\end{array}$ & $\begin{array}{c}50,1 \\
0,2\end{array}$ & $\begin{array}{c}43,8 \\
0,3\end{array}$ \\
\hline $\begin{array}{l}\text { Середньооблікова кількість } \\
\text { штатних працівників, } \\
\text { тис.осіб } \\
\text {-у т.ч. морський транспорт }\end{array}$ & $\begin{array}{c}824,3 \\
9,6 \\
\end{array}$ & $\begin{array}{c}661,4 \\
3,8 \\
\end{array}$ & $\begin{array}{c}659,9 \\
3,4 \\
\end{array}$ & $\begin{array}{c}655,2 \\
2,3 \\
\end{array}$ & $\begin{array}{c}648,4 \\
2,6 \\
\end{array}$ & $\begin{array}{c}635,1 \\
2,5 \\
\end{array}$ \\
\hline $\begin{array}{l}\text { Експорт-імпорт } \\
\text { транспортних послуг, } \\
\text { Експорт, млн. дол. США } \\
\text {-з них послуги морського } \\
\text { транспорту } \\
\text { Імпорт, млн. дол. США } \\
\text {-з них послуги морського } \\
\text { транспорту }\end{array}$ & $\begin{array}{c}1178,9 \\
143,0\end{array}$ & $\begin{array}{c}1153,3 \\
191,7\end{array}$ & $\begin{array}{c}8300,5 \\
661,6\end{array}$ & $\begin{array}{c}5861,4 \\
612,1\end{array}$ & $\begin{array}{c}1462,8 \\
223,0\end{array}$ & $\begin{array}{c}1559,1 \\
273,8\end{array}$ \\
\hline
\end{tabular}

Варто відзначити основні причини, що спричинили таку негативну динаміку показників використання морського транспорту в Україні, серед яких є:високий рівень зносу основних фондів флоту (більше 85\% суден перевищили нормативний термін служби, і майже половина з них мають вік більше 20 років), незадовільний стан припортової інфраструктури, стагнація виробничих потужностей українського суднобудування, недостатність власних обігових коштів для оновлення і модернізації морально та фізично спрацьованого флоту та низький рівень його державної підтримки, тощо. Крім того, серед негативних тенденцій функціонування морського транспорту відмічається низький рівень інноваційної діяльності, обмеженість здійснення науково-дослідних та дослідно-конструкторських робіт у розбудові морської галузі, посилення проблем у соціальній сфері діяльності підприємств морської індустрії (забезпечення робочими місцями, забезпечення достатнього рівня оплати праці, дієва система стимулювання працівників морської галузі, тощо) [1, с.88].

Важливим кроком становлення і подальшого розвитку України як морської держави стала «Морська доктрина України на період до 2035 року», що набула чинності 18 грудня 2018 р. та яка покликана сприяти підвищенню ефективності використання усіх різновидів ресурсів моря та успішній реалізації державної морської політики, від яких залежать суверенітет і територіальна цілісність України, ії економічна та енергетична незалежність, 
сталий розвиток та інтеграція в євроатлантичний простір [2]. Україна активно співпрацює з Європейською комісією та міжнародними компаніями з метою розробки чіткого механізму гармонізації законодавчої бази у сфері водних шляхів. Крім того, вже сьогодні можна відзначити низку прийнятих управлінських заходів відповідно до вищезазначеного, а саме:

- здійснюються роботи щодо імплементації положень Угоди про асоціацію України з $\in C$, директив та регламентів ЄС у сфері міжнародного морського та внутрішнього водного транспорту;

- продовжується реформа системи управління морською галуззю, створено Державну службу морського і річкового транспорту [3];

- продовжується фінансування бюджетної програми «Здійснення заходів щодо підтримки впровадження транспортної стратегії України»;

- встановлення навігаційного обладнання вздовж берегової лінії, що сприятиме переходу на європейський рівень здійснення заходів з державного нагляду і контролю за безпекою на водному просторі України, тощо.

Таким чином, можна зробити висновок, що зміцнення авторитету України на міжнародній арені та поглиблення партнерських зв'язків з морськими державами вимагають прийняття відповідних управлінських заходів щодо відновлення потенційних можливостей підприємств морського транспортного комплексу вітчизняної економіки, які виступають базисом реалізації зовнішньо- і внутрішньополітичних пріоритетів, економічних і соціальних інтересів в умовах сьогодення. Відновлення потенціалу морського транспорту України потребує удосконалення системи управління його розвитком з використанням особливого цільового підходу, орієнтованого на забезпечення загальнонаціональних інтересів у морській галузі, створення єдиних економічних умов розвитку флоту і торгових портів відносно різних форм власності, визнання українських суб'єктів морського транспорту в якості рівноправних учасників світового фрахтового ринку. Особливу увагу слід приділити формуванню стратегії розвитку морського транспортного потенціалу України, одною із важливих цілей якої має стати відновлення і зміцнення іміджу підприємств морського транспорту як структурної ланки світового ринку транспортних послуг.

\section{Список використаних джерел}

1. Гришина Л.О., Карась П.М., Приходько Н.В. Розвиток суднобудівної індустрії в контексті реформування транспортної системи України. Вісник економіки транспорту і промисловості, 2017. № 58. С. 86-96.

2. Постанова Кабінету Міністрів України від 18 грудня 2018 р. № 1108 «Морська Доктрина України на період до 2035 року». URL: http://search.ligazakon.ua

3. Постанова кабінету міністрів України №1095 від 6.09.2017р. «Про створення Державної служби морського і річкового транспорту» URL: http://zacon.rada.gov.ua

4. Офіційний сайт Державної служби статистики України. URL: http://www.ukrstat.gov.ua 


\title{
DIGITALIZATION OF THE MARITIME INDUSTRY: ADVANTAGES AND DISADVANTAGES
}

\author{
Mihai N.B., \\ PhD, Associate Professor \\ Admiral Makarov National University of Shipbuilding, \\ Mykolaiv, Ukraine
}

\section{ДІДЖИТАЛІЗАЦІЯ МОРСЬКОЇ ГАЛУЗІ: ПЕРЕВАГИ ТА НЕДОЛІКИ}

\author{
Мігай Н.Б., \\ к.е.н., дочент
}

Національний університет кораблебудування імені адмірала Макарова

Миколаїв, Україна

Необхідність прискореного впровадження цифрових технологій в економічній та соціальній сфері, особливо в останній час в умовах пандемії, вимагає формування та застосування нових технологій і в транспортній галузі. Завдання цифровізації морських портів на сьогодні $€$ одним із першочергових не тільки в Україні, а й в усьому світі. Діджиталізація у транспортній галузі стала одним із світових трендів і дозволяє оптимізувати логістику, мінімізувати витрати та підвищити ефективність перевезень, а це в свою чергу, забезпечує конкурентні переваги країни на світовому ринку. В той же час впровадження нових технологій породжує велику кількість проблем, які не можливо вирішити виключно технічними чи технологічними засобами. Для цього необхідні адекватні політичні та правові рішення, законодавчо-нормативна база, які б встановлювали «правила гри» для всіх суб'єктів, які задіяні в сфері транспортних перевезень.

Основні переваги та недоліки, що створює процес діджиталізації відображено в табл. 1.

Табл.1. Переваги та недоліки діджиталізації для суб’єктів транспортної галузі

\begin{tabular}{|l|l|}
\hline \multicolumn{1}{|c|}{ Переваги } & \multicolumn{1}{|c|}{ Недоліки } \\
\hline Економія ресурсів & Скорочення робочих місць \\
\hline Автоматизація бізнес процесів & Ризик кібератак \\
\hline Електронний документообіг технічні збої обладнання \\
\hline $\begin{array}{l}\text { Прозорість, можливість аналізу та } \\
\text { прогнозування }\end{array}$ & $\begin{array}{l}\text { Переважно закордонні } \\
\text { програмного забезпечення (для України) }\end{array}$ \\
\hline $\begin{array}{l}\text { Он-лайн розрахунки } \\
\text { Персоналізація для різних категорій клієнтів }\end{array}$ & $\begin{array}{l}\text { Цалежність від цифорвізації } \\
\text { населення неграмотність більшої частини }\end{array}$ \\
\hline Підвищення екологічності суднових операцій & \begin{tabular}{l} 
Небезпека пов'язана із відсутністю екіпажу \\
\hline
\end{tabular} \\
\hline
\end{tabular}


на борту судна

В сфері морських перевезень на сьогодні найбільш актуальними серед великої кількості IT-технологій є кібербезпека, інтернет речей, технологія блокчейн та автоматизовані судна (дрони).

Останнім часом кібератаки показали уразливість навігаційних та інших інформаційних систем суден та морських портів. Відбувається втручання в системи автоматичної ідентифікації та електронні карти, глушіння глобальних систем позиціонування та маніпулювання системами управління вантажами та суднами, запуск програм-вірусів тощо. При цьому міжнародні правила кібербезпеки для морської галузі ще не прийняті, але $\epsilon$ принципи по управлінню ризиками кібербезпеки розроблені International Maritime Organization (IMO), які визначають рекомендації високого рівня в царині захисту міжнародного судноплавства від існуючих і потенційних загроз у сфері кібербезпеки.

Інтернет речей (Internet of things) являє собою мережу підключених приладів 3 унікальними ідентифікаторами у вигляді адрес інтернет-протоколів, оснащених технологіями, які дозволяють сприймати, збирати дані та повідомляти про середовище, в якому вони знаходяться або про них самих [1, с. 20].

В морській галузі найчастіше використовуються дані, отримані із супутників, датчиків, що зв'язують обладнання, системи і механізми для підтримання, прийняття обґрунтованих рішень з оптимізації маршрутів, відслідковуванню об'єктів та технічним обслуговуванням механізмів.

Для прикладу порти Ротердам, Гамбург використовують ІоТ-датчики, технології доповненого інтелекту, які дозволяють отримати дані про доступність причалів, відпрацювання різних сценаріїв роботи, координації трафіку руху суден та управління діяльністю портових команд.

Технологія блокчейн - це технологія розподіленого реєстру, яка дозволяє безпечно записувати операції в реєстрі в декількох місцях одночасно і через кількох окремих осіб без необхідності залучення адміністрації чи посередників.

Перевагами застосування технології блокчейн $є$ підвищення безпеки інтернету речей, кібербезпеки, можливість блокування крадіжки персональних даних, використання криптографії з відкритим ключем тощо.

Корисність блокчейн для морської галузі в тому, що технологія може використовуватись для відслідковування переміщення вантажів, реєстрації відомостей про судна, ризики перевезень, для інтерактивних контрактів та морських страхових полісів, автоматизації процесів оброблення документів.

В світовій практиці в морських портах, транспортній галузі взагалі технологія блокчейн вже застосовується. Так, транспортним конгломератом Maersk та американською ITкорпорацією IBM створено спільний проект TradeLens - блокчейн платформа, якою користуються більше 150 учасників для організації контейнерної логістики та відстеження вантажів. До екосистеми TradeLens входять більше 100 морських портів та портових 
операторів, більше 20 морських перевізників та інтермодальних операторів, більше 10 митниць інших країн та одна з провідних міжнародних банківських груп [2]. У 2020 році Українська митниця також приєдналася до TradeLens. Також, Україні в портах Миколаїв, Одеса, Південний, Ольвія відбувається успішне впровадження системи e-Port 4.0.

Автоматизовані судна (безпілотні, роботизовані) здатні забезпечити підвищену безпеку та економію коштів за рахунок відокремлення від людського фактора в окремих операціях. Автоматизовані судна можуть використовуватися у різних операціях, зокрема рятувальних, ліквідації аварій, розливів нафти, пасажирських поромних перевезень, буксируванні вантажів тощо. На даний час такі судна переважно використовуються в проведені морських наукових досліджень у оборонній сфері. На сьогодні велика кількість компаній займаються розробкою автоматизованих суден, серед них, норвезька "Үara» 3 «Kongsberg Gruppen», французька «Bourbon», британський «Rolls-Royce», японські «Mitsui O.S.K. Lines», «Nippon Yusen» та «Japan Marine United»[3, с. 114] . При цьому основними завданнями при роз розробці і впровадженні таких суден $\epsilon$ їх надійна робота та безпека, адже замінити повністю роботу висококваліфікованих спеціалістів в морській галузі штучному інтелекту на сьогодні ще не можливо.

Таким чином, незважаючи велику кількість переваг від діджиталізації в морській галузі, існує також велика кількість недоліків та ризиків в економічній і правовій сфері, сфері соціально-трудових відносин, безпеки життєдіяльності та навколишнього середовища, які обов'язково необхідно враховувати при їі впровадженні.

\section{Список використаних джерел}

1. Богомазова В.М., Т.К. Кваша. Аналіз перспективних світових наукових та технологічних напрямів досліджень за Ціллю сталого розвитку № 9 щодо транспортної сфери з використанням інструментів платформ «Web of Science» та «Derwent Innovation»:науковоаналітична записка. К.: УкрIHTEI. 2020. -33 с.

2. Переміщення морських вантажів: митниця приєдналася до блокчейнплатформи TradeLens. URL: http://www.visnuk.com.ua/uk/news/100017365-peremischennyamorskikh-vantazhiv-mitnitsya-priyednalasya-do-blokcheyn-platformi-tradelens

3. Плачкова Т.М. Проблеми правового регулювання безпеки автономного судноплавства. Правова держава. №30. 2018. С. 114-117. 


\section{ECOLOGICAL MANAGEMENT IN IMPLEMENTATION OF ENVIRONMENTAL GOALS OF THE REGION}

Nekhai V.,

Doctor of Economics, Associate Professor

Dmytro Motorny Tavriya State Agrotechnological University, Melitopol, Ukraine

Nesterenko S.,

Doctor of Economics, Professor

Dmytro Motorny Tavriya State

Suprunenko S.,

Doctor of Economics, Associate Professor, University of State Fiscal Service of Ukraine, Irpen, Ukraine,

Nesterenko O.,

PhD in Economics,

Dmytro Motorny Tavriya State Agrotechnological University, Melitopol, Ukraine,

Nikitina T.,

Graduate student,

Dmytro Motorny Tavriya State Agrotechnological University, Melitopol, Ukraine

\section{ЕКОЛОГІЧНИЙ МЕНЕДЖМЕНТ У РЕАЛІЗАЦІЇ ЕКОЛОГІЧНИХ ЦІЛЕЙ РЕГІОНУ}

Нехай В.В., доктор економічних наук, дочент,

Таврійський державний агротехнологічний університет ім. Дмитра Моторного, Мелітополь, Україна,

Нестеренко С.А., доктор економічних наук, професор, Таврійський державний агротехнологічний університет ім. Дмитра Моторного, Мелітополь, Україна,

Супруненко С.A., к.е.н., дочент, Університет державної фіскальної служби України, Київ, Україна, Нікітіна T.P., Таврійський державний агротехнологічний університет ім. Дмитра Моторного, Мелітополь, Україна

Неокласична економічна теорія визначає екологічний менеджмент, як інтеграційний науковий напрямок. Він поєднує наукові завдання управління, природокористування, економіки, медицини, права. Цей синтез вимагає створення уніфікованих методологічних засад ефективної взаємодії елементів екологічного менеджменту як цілісної системи.

Для вирішення науково-практичного завдання розглянемо та обґрунтуємо підходи до організації екологічного менеджменту для виконання екологічних цілей регіону. За 
критерієм «тип організації» пропонуємо їх поділити на прямий та опосередкований стосовно вирішення екологічних проблем. Кожен з цих підходів має певні позитивні риси, тому на практиці обидва застосовуються та можуть поєднуватись у застосуванні в одному і тому ж регіоні.

Прямий підхід екологізації реалізується діяльністю організацій, які безпосередньо виконують функції екологізації умов існування суспільства і людини. Серед таких організацій важливе місце займають, наприклад, лісомисливські господарства. Для поточнення значення, конкретизації місії та виокремлення з-поміж існуючих, пропонуємо для означення прямого типу організації та здійснення екологічного менеджменту застосувати термін «продуктивний метод здійснення екологічного менеджменту».

Опосередкований підхід до екологізації регіону полягає у впровадженні та реалізації екологічного менеджменту на підприємствах, які самі ж створюють у певній мірі в регіоні дислокації екологічні проблеми. Для того, щоб більш конкретно означити саме такий підхід пропонуємо застосовувати дефініцію «регенераційний метод здійснення екологічного менеджменту». Найбільш повно екологічний менеджмент здійснює свою основну місію реалізацією регенераційного методу.

Обрання структури та підходів до здійснення екологічного менеджменту цим методом зводиться до вирішення питання про те, які обов'язки повинні виконувати різні учасники процесу забезпечення екологічної безпеки.

у «Регіональній доповіді» Департаменту екології та природних ресурсів Запорізької обласної державної адміністрації зазначається, що «перехід на інноваційно-технологічний шлях розвитку в державі має відбуватись на базі визначених пріоритетів 3 метою формування національної інноваційної системи і цілісної структури науково-технічного комплексу, здатного стало функціонувати в умовах глобалізації. Основними напрямками інноваційного розвитку мають бути:

- екологічна реструктуризація та екологічна модернізація виробництва, що передбачає зміну галузевої структури шляхом зниження попиту на продукцію екологічно брудних виробництв або шляхом модернізації підприємств - споживачів такої продукції;

- розробка та використання природоохоронних технологій, зокрема, застосування технологій утилізації відходів, рециклювання ресурсів після їх обробки, рекультивація порушених земель;

- запровадження на промислових підприємствах систем екологічного менеджменту, що $€$ сучасним механізмом управління природоохоронною діяльністю, функціонування якого сприяє покращенню екологічних показників підприємств;

- формування екологічних вимог до розробки нових, запровадження в практику жорсткого екологічного контролю наявних технологій відповідно до сучасних екологічних нормативів та стандартів» [1].

Останні два з визначених напрямків інноваційного розвитку національної інноваційної системи і цілісної структури науково-технічного комплексу, здатного стало функціонувати в 
умовах глобалізації, вказують на необхідність створення та розвитку системи екологічного менеджменту на промислових підприємствах регіонів України.

До визначених пріоритетів забезпечення ефективності функціонування екологічного менеджменту у якості організаційно-методичних заходів їхнього закріплення доцільно рекомендувати:

- забезпечення повної обізнаності персоналу підприємства про екологічні цілі регіону й країни;

- удосконалення організаційних структур управління підприємством у напрямку виокремлення підрозділу з екологічного менеджменту;

- забезпечення системи управління підприємством необхідними для повноцінного функціонування екологічного менеджменту кадровими, технічними, інформаційними ресурсами;

- адаптація підприємства до екологічного правового простору не лише України, а й інших країн;

- перманентний моніторинг екологічних заходів інших підприємств;

- використання світового досвіду втілення екологічного менеджменту у досягненні екологічних цілей регіону;

- популяризація та пропаганда екологічних цінностей через поширення інформації про екологічне законодавство, досвід досягнення екологічної стабільності у країнах, регіонах.

Втілення рекомендованих заходів має бути індикаторами запровадження екологічного менеджменту для досягнення екологічних цілей регіону й країни.

Висновки. Для сталого функціонування регіонів та галузей економіки нашої країни розв'язання екологічних питань має бути пріоритетним та першочерговим. Обираючи цілі стратегічного регіонального розвитку, слід узгоджувати їх з керівництвом виробничих підприємств, які формують промисловий базис регіону, та орієнтувати їх на розроблення науково обгрунтованих заходів з підтримання екологічної безпеки та втілення концепції екологічного менеджменту у загальногосподарську управлінську діяльність.

\section{Список використаних джерел:}

1. Регіональна доповідь про стан навколишнього природного середовища у Запорізькій області у 2017 році. URL:

https://mepr.gov.ua/files/docs/Reg.report/2017/\%D0\%97\%D0\%B0\%D0\%BF\%D0\%BE\%D1\%80\%D1 \%96\%D0\%B7\%D1\%8C\%D0\%BA\%D0\%B0\%20\%20\%D0\%A0\%D0\%95\%D0\%93\%D0\%86\%D0\%9E\%D0\% 9D.\%20\%D0\%94\%D0\%9E\%D0\%9F\%D0\%9E\%D0\%92.2017.pdf (дата звернення: 16.03.2021)

2. Ліпич Л. Г., Глубіцька Т.В. Впровадження екологічного менеджменту на підприємствах хімічного комплексу. URL: http://ena.lp.edu.ua/bitstream/ntb/23265/1/10-5964.pdf (дата звернення: 19.03.2021). 
3. Василенко Л.О., Березницька Ю.О., Жукова О.Г. Розвиток екологічного менеджменту на підприємстві в умовах глобалізації економіки України. Економіка ma держава. 2017.№8. Київ: ДКС Центр, С. 62-65

4. Пашкевич М.С., Паламарчук Т.О. Екологізація виробництва підприємств України. URL: http://www.economy.nayka.com.ua/?op=1\&z=1624 (дата звернення: 21.03.2021).

5. Нехай В.В. Посилення ролі і значимості маркетингу на машинобудівному підприємстві. Актуальні проблеми економіки, 2011. № 2 (116), С. 96-99.

\title{
TECHNOLOGIES IN LOGISTICS IN THE CONDITIONS OF WIDE GLOBALIZATION AND DIGITALIZATION
}

\author{
Khmarska I.A., \\ PhD, Associate Professor, \\ Admiral Makarov National University of Shipbuilding, \\ Mykolaiv, Ukraine
} ТЕХНОЛОГІї В ЛОГІСТИЦІ В УМОВАХ ШИРОКОЇ ГЛОБАЛІЗАЦІї ДІДЖИТАЛІЗАЦІї

Хмарська І.А., к.е.н., доцент Національний університет кораблебудування імені адмірала Макарова Миколаїв, Україна

У 2000 році Міжнародний валютний фонд ідентифікував чотири базові аспекти глобалізації: торгівлю й фінансові транзакції, рух капіталу та інвестицій, міграцію людей та розповсюдження знань. 3 глобалізацією пов'язують також проблеми довкілля, наприклад глобальне потепління, забруднення вод за межами кордонів, забруднення повітря та надмірний вилов риби в океанах. Процеси глобалізації впливають на бізнес та зайнятість, економіку, соціо-культурні ресурси та на природне довкілля. В академічній літературі глобалізацію зазвичай розбивають на три основні області: економічну, культурну та політичну глобалізацію [1].

Діджиталізація - переведення інформації в цифрову форму. Більш технологічне визначення: цифрова трансмісія даних, закодованих у дискретні сигнальні імпульси. Простіше сказати що, діджиталізація це перенесення, групування, зберігання, транспортування всієї інформації до гіперпростору, що забезпечить ефективніше використання цієї інформації.

Згідно зі звітом PWC, 54\% опитаних транспортних та логістичних компаній очікують, що діджиталізація збільшить їхні доходи. Вони також стверджують, що онлайн-біржі $є$ дуже 
важливими у повсякденному житті експедиторів та логістичних операторів і відіграють важливу роль в організації перевезень [2].

Ці вимоги випливають безпосередньо з потреб клієнтів у вигляді прозорості операцій та економії часу. Ті, хто не адаптується, перестануть бути конкурентоспроможними. Великі експедиторські компанії, які розвивають свою конкурентоспроможну перевагу, підвищуючи якість та ефективність послуг, використовують онлайн-платформи, де вони з'єднують вантажі вантажовідправників з перевізниками. Цифрові платформи, на кшталт Trans.eu Platform, вже пропонують сучасні рішення, такі як: оптимізація роботи на постійних маршрутах, автоматизований пошук клієнтів та пропозицій за допомогою алгоритмів. Запорукою цієї трансформації $€$ не нове обладнання, та нові способи обробки даних [3].

Big data та його інтелектуальний аналіз дають нам можливість економити операційні витрати, ефективніше використовувати наші ресурси, швидше спілкуватися, досягати прозорості даних у ланцюзі поставок та здійснювати аналіз в режимі реального часу. Він змінює рамки, в яких взаємодіють люди, підприємства та організації. Інструменти які доступні на найсучасніших логістичних платформах: автоматизований пошук контрагентів (Автоматизація завдяки діджиталізації вже починається 3 пошуку перевізників. Інтелектуальний підбір перевізників, можливість створення груп контрагентів,допомагає швидко та ефективно знайти відповідний вантаж або транспорт для вантажу; відхід компаній від паперових документів.

у цифрових платформах всі документи можна швидко і легко адаптувати та надсилати. Крім того, ці документи архівуються в системі, так що ви завжди можете повернутися до них. Цифрова трансформація створює можливості для нових бізнесконцепцій, отримання доходу та підвищення ефективності.

У міру того як все більше учасників світового логістичного ринку переймаються підвищенням прозорості та надійності ланцюгів поставок, провідні ІТ-компанії просувають ідею використання для цих цілей технології blockchain.

Так, міжнародна IT-компанія IBM вже запропонувала деяким великим компаніям 3 різних сфер діяльності протестувати свої розробки, засновані на принципі blockchain. Міжнародний Blockchain-консорціум Hyperledger був запущений Linux Foundation в 2015 році і на даний момент об'єднує понад 115 компаній з різних сфер, включаючи фінанси, автомобілебудування, охорону здоров'я, ІоТ і авіацію. Головна мета консорціуму - створення єдиної blockchain-платформи з відкритим вихідним кодом, яка дозволить організаціям по всьому світу впровадити технологію blockchain в свої бізнес-процеси.

Рітейлер WalMart одним з перших повірив у світле майбутнє blockchain, він тестує нову технологію IBM на поставках манго в США і свинини в Китаї. Як вважають в компанії, їі впровадження підвищить ефективність управління запасами і забезпечить безпеку поставляються продуктів харчування, що WalMart вважає особливо важливим після спалаху сальмонельозу в 2006 році. У той час, при використанні паперового документообігу, на ідентифікацію джерела інфекції у компанії пішло близько двох тижнів. Блокчейн дозволить 
отримати повну інформацію про будь-якої партії товару, занесеної до бази даних, за лічені секунди, стверджують прихильники технології.

У глобальні перспективи технології вірять не тільки ії адепти. Нещодавно стало відомо, що конкурент IBM, компанія Microsoft, також веде розробки в цьому напрямі, спільно з JPMorgan Chase і іншими великими фінансовими корпораціями, взявши за основу альтернативну технологію віртуальної валюти Ефіріума (Ethereum).

Хмарний blockchain-сервіс Azure Blockchain-as-a-Service (Baas) був запущений в кінці 2015 року, і з тих пір Microsoft взаємодіє з замовниками та партнерами для отримання відгуків та пропозицій по відсутньою частин свого рішення, необхідне для того, щоб організації могли і хотіли впроваджувати blockchain-додатки. У 2017 компанія оголосила про запуск нової ініціативи під назвою Project Bletchley, метою якої стане надання допомоги компаніям, які представляють різні сектори економіки, зі створенням консорціумів 3 вивчення та впровадження технології blockchain.

Проект IBM Food Trust об'єднав 10 таких великих виробників і розповсюджувачів продуктів харчування як Dole, Driscoll's, Golden State Foods, Kroger, McCormick and Company, McLane Company, Nestlé, Tyson Foods, Unilever i Walmart.

Система являє собою хмарне рішення засноване на IBM Blockchain. Сервіс зберігає дані про більш ніж 1 мільйон продуктів харчування на блокчейн-платформі IBM і Hyperledger Fabric. IBM Food Trust використовує блокчейн і дає всім учасникам доступ до прозорого, постійного і розподіленого реєстру записів про походження продуктів харчування, інформації про статус транспортування, поточний стан і багато іншого.

Блокчейн створює нове середовище для спільної роботи з даними, в якій можуть співпрацювати навіть прямі конкуренти. Всі учасники можуть налаштовувати рівні доступу і безпечно співпрацювати, оскільки завдяки технології блокчейна дані зберігаються в цифровій формі, є розподіленими і незмінними.

Довірені учасники і децентралізація мережі підвищують рівень безпеки. Довірені учасники - провідні учасники мережі IBM Food Trust - несуть колективну відповідальність за підтримку цілісності загального реєстру і надають всім учасникам спільноти допомогу в забезпеченні безпеки, конфіденційності та дотримання дозволів на доступ до даних.

Висновки. Сьогодні логістичною діяльністю займаються великі підприємства, які мають промислові потужності та реалізацією свого товару, а малі підприємства користуються послугами логістичних компаній. Ми впевнені, що за IBM Food Trust, технологією майбутнє не тільки в сфері логістики, а й в принципі у всій світовій економіці, та економічних законах.

\section{Список використаних джерел}

1. [Електронний ресурс].-Режим доступу: //logist.fm/publications/tehnologiyablockchain-v-logistike 
2. Коваленко О.О., Марценюк Т.О., Яворська І.О. Проблеми використання інформаційних логістичних систем на українських підприємствах. Економічний простір. 2015, № 19. С. 274-282.

3. IBM Food Trust [Електронний ресурс]. - Режим доступу: //www.ibm.com

\title{
SELECTION OF A BULK VESSEL UNDER THE CONDITIONS OF ITS OPERATION AT DIFFERENT SPEEDS
}

\author{
Glavatskhih V.I., \\ assistant, \\ Odessa National Maritime University \\ Odesa, Ukraine
}

\section{ВИБІР СУДНА-БАЛКЕРА ЗА УМОВИ ЙОГО ЕКСПЛУАТАЦІї НА РІЗНИХ ШВИДКОСТЯХ}

Главатських B.I., асистент, Одеський національний морський університет Одеса, Україна

Одним з найважливіших факторів, що впливає на ефективність експлуатації морського флоту, $є$ швидкість руху суден. Від вибору швидкості суден залежить час доставки вантажів і пасажирів, провізна здатність суден, а також витрата палива, собівартість доставки вантажів та кількість шкідливих викидів.

Значний вплив на показники ефективності роботи судноплавних компаній мають характеристики вантажопотоків, кон'юнктура фрахтового ринку, особливості навігації та погодні умови, особливості роботи суміжних видів транспорту та ряд інших факторів [1].

Час доставки вантажу $€$ одним з найважливіших показників якості діяльності судноплавної компанії. Експлуатація суден на знижених швидкостях дозволяє досягти суттєвого зменшення рівня споживання пального і, як наслідок, зменшення експлуатаційних витрат. Тому при виборі оптимальної швидкості руху суден важливим є дотримання балансу між часом доставки вантажу і економічними показниками експлуатації судна [2, с. 3].

Наслідком нестабільної економічної ситуації в світі $\epsilon$ мінливі умови діяльності в галузі морських перевезень. Для того щоб залишатися конкурентоспроможними на ринку, більшість судноплавних компаній змушені вживати заходи задля підвищення ефективності використання енергетичних ресурсів [3, с.165]. Частково це пов'язано з коливаннями цін на нафту та пально-мастильні матеріали. Тому багато уваги передових судноплавних компаній спрямовано на розробку заходів щодо зменшення витрат на паливо. До них можна віднести наступні заходи з організації перевезень: перерозподіл суден, об'єднання маршрутів, 
зниження експлуатаційної швидкості, припинення обслуговування менш рентабельних напрямків, заходи з вдосконалення конструкції корпусу, нові технології для суднових двигунів, використання альтернативних джерел енергії, комп'ютерні технології інші [4; 5].

Основною складовою видатків, що істотно впливають на отримання прибутку при використанні кожного судна, є вартість спожитого в рейсі палива. Ця видаткова частина становить до 60\% від загальних витрат і може змінюватися в широких межах залежно від умов експлуатації та дій екіпажу з підтримання раціональних технологічних режимів. Економію паливно-енергетичних ресурсів на суднах слід вважати важливим комплексним завданням, що вимагає ефективного вирішення не тільки тому, що при цьому забезпечується максимум прибутку, а, перш за все, з тієї причини, що раціонально витрачаються не поновлювані енергетичні ресурси, зменшується обсяг викидів в атмосферу продуктів згоряння, зберігається екологічно чисте середовище на водних комунікаціях. Отже, із зменшенням витрат палива заощаджується моторесурс головних двигунів судна, генераторних агрегатів суднових електростанцій, знижується теплонапруженість деталей і вузлів суднових машин і механізмів, зменшуються витрати мастила та ін [6; 7].

Економія палива при експлуатації судна може бути здійснена кількома шляхами. Один 3 них полягає в оновленні флоту досконалими судами нового покоління, які оснащені сучасними економічними двигунами. Цей шлях пов'язаний з залученням значних інвестицій. Інший шлях економії палива при експлуатації судна полягає в виборі та забезпеченні оптимальних режимів роботи суднової дизельної установки, а також проведенні різних організаційно-технічних заходів щодо економії паливно-енергетичних ресурсів. Зниження швидкості ходу при експлуатації судна дозволяє судновласнику скоротити експлуатаційні витрати по судну, що широко застосовується на практиці. Однак, слід враховувати, що надмірне зниження швидкості може призвести до втрати клієнтури і, як наслідок, до можливого зменшення доходів. Тому значний інтерес представляють дослідження залежності витрат палива від експлуатаційної швидкості суден [8].

Зображення на рис. 1 дозволяє дослідити рішення задачі багатокритеріальної оптимізації за двома критеріями (середній ходовий час в одному напрямку та загальне значення показника NPV (Net Present Value) проекту придбання судна), що надає можливість особі, яка приймає рішення, зробити обґрунтований вибір щодо можливості експлуатації судна на різних швидкостях [9].

При досліджені задач багатокритеріального аналізу вичерпна об'єктивна інформація стає доступною, коли знайдено множину Парето. Далі на підставі інформації про множину Парето особа, яка приймає рішення, має зробити свій остаточний вибір одного з розв'язків, що неможна покращити. Роблячи такий вибір, особа, яка приймає рішення, може використати додаткові критерії та міркування, або покладатися на свої професійні знання, досвід та інтуїцію. Отже, при розв'язанні задачі багатокритеріального аналізу, перш за все повинен бути визначений та описаний набір рішень, з яких слід здійснювати вибір. Разом $з$ 
поняттям рішення використовують також терміни альтернатива, варіант, план або стратегія $[10 ; 11]$.

Очевидно, що найкращих значень NPV і найменшої тривалості рейсу одночасно досягти неможливо. Одним з цих критеріїв неминуче доведеться поступитися, якщо намагатися покращити інший. Отже, це є типовою задачею багатокритеріальної оптимізації. Для того, щоб розв'язати цю задачу треба знайти множину Парето - оптимальних значень. Для визначення Парето - оптимальних зазначень надаємо наглядний графічний спосіб представлення залежності значень критеріїв один від одного.

Таким чином, бачимо що судну “D” з точки зору максимізації значення таймчартерного еквівалента (TCE, Time-Charter Equivalent ) вигідніше за все рухатися зі швидкістю 11,04 вузлів, тому що для цієї швидкості значення ТСЕ $€$ найбільшим та становить 8658,63 дол./доб. Аналогічно визначаються найбільш ефективні, з огляду на значення, швидкості для судна “A" - 12,3 вузлів, судна “B" - 11,2 вузлів та 9,6 вузлів для судна “C". На рис. 1 представлено порівняння значень середньозваженого ТСЕ в залежності від швидкості руху для всіх суден-претендентів.

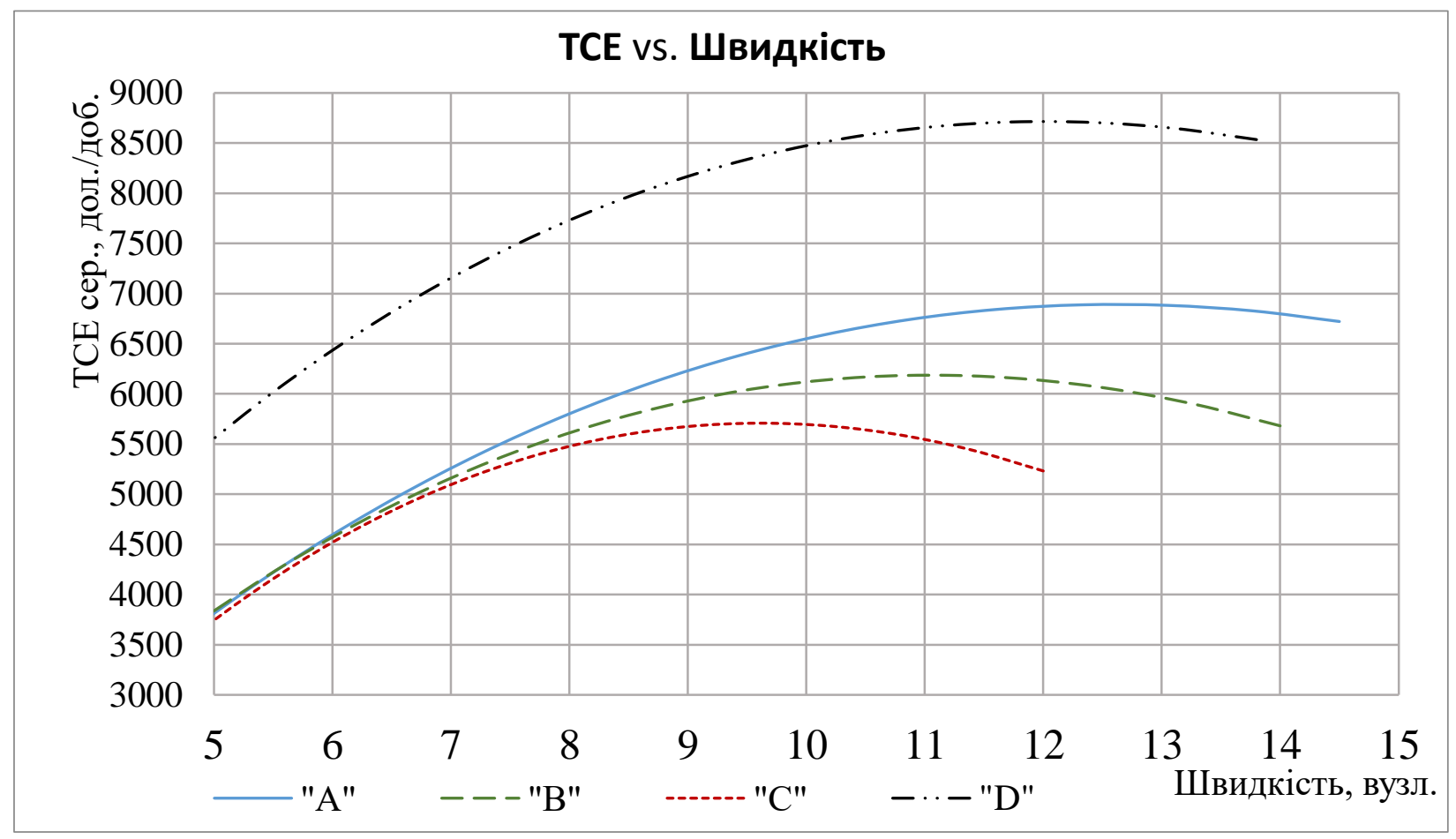

Рис. 1. Порівняння залежностей ТСЕ від швидкості для всіх суден, що розглядаються

Висновки. Аналізуючи дугу, що відповідає судну “ $A$ ", можна зробити висновок про те, що проект придбання та подальшої експлуатації судна “A” може розглядатися лише тоді, коли необхідно забезпечити максимально короткі строки доставки вантажу. Але в широкому діапазоні середніх та повільних швидкостей судно “A” показує незадовільні показники економічної ефективності. Проект придбання судна “D” взагалі виглядає непривабливим, бо показник NPV є найменшим серед суден-претендентів, хоча строки доставки вантажу в нього малі. Якщо аналізувати дуги на рис. 1, то можна дійти до висновку про те, що проект 
придбання судна "B" $є$ найбільш ефективним, якщо існують обмеження на те, щоб рейс в середньому тривав не більше 33 діб. Якщо ніяких обмежень на тривалість доставки вантажів клієнти накладати не будуть, то найбільш ефективним з економічної точки зору є проект придбання та експлуатації судна "C" і використання його на швидкості 12,3 вузлів, при цьому середня тривалість ходового часу в одному напрямку буде найбільшою і становитиме приблизно 36 діб.

При виборі судна також слід приділити увагу довжині діапазону швидкостей, на яких використання судна $€$ оптимальним. Якщо використання судна $€$ оптимальним в широкому діапазоні швидкостей, то судноплавна компанія в майбутньому може забезпечити додаткову гнучкість в узгодженні фрахтових ставок і строків доставки вантажів через можливість ефективної експлуатації суден на різних швидкостях, що є дуже важливим в умовах нестійкої кон'юнктури фрахтового ринку.

\section{Список використаних джерел:}

1. Лапкина И.А. Моделирование принятия решений в управлении работой флота судоходной компании / И.А. Лапкина. - Одесса: ОГМУ, 1996. - с. 203

2. Брошков С.Д. Выбор экономической скорости хода судна с учетом характеристик главного двигателя / С.Д. Брошков // автоматизация судовых технических средств. Одесса: Изд-во ОНМА, - 2010. № 16. - с. 3-10.

3. Лапкина И.А. Определение оптимальной эксплуатационной скорости судовконтейнеровозов при изменении объемов перевозок на линии / И.А. Лапкина, О.В. Акимова // Методи та засоби управління розвитком транспортних систем. - №18. - Одесса: изд-во OHMУ, - 2011. - C. 165-181.

4. Винников В.В. Экономика предприятия морского транспорта (экономика морских перевозок): Учебное пособие / В.В. Винников. - Одесса: Изд-во Латстар, 2001. - с. 416

5. Дидык А.Д. Управление судами и его техническая эксплуатация: Учебник для мореходных училищ / А.Д. Дидык, В.Д. Усов, Р.Ю. Титов. - М.: Транспорт, 1990. - с. 320

6. Ковалев В.В. Методы оценки инвестиционных проектов / В.В. Ковалев - М.: Финансы и статистика, 1998. - 144 с.

7. Раховецкий А.Н. Оперативная фрахтовая деятельность на морском транспорте / А.Н. Раховкцкий . - М.: Транспорт, 1986. - 160 с.

8. Капитонов И.В. Резервы эффективности эксплуатации морских судов / И.В. Капитонов. - М.: Транспорт, 1990. - 221 с.

9. Лапкіна І.О. Аналіз інвестиційного проекту судноплавної компанії: навч. Посібник / І.О. Лапкіна, Л.А. Павловська, М.А. Ветошнікова. - Одеса: Вид-во ОНМУ, 2006. - с. 480

10. Лотов А.В., Поспелова И.И. Многокритериальные задачи принятия решений: Учебное пособие. - М.: МАКС Пресс, 2008. - с.197 
11. Краев В.И. Экономическая оценка инвестиций на водном транспорте / В.И. Краев, Т.А. Пантина. - СПб.: Изд-во СПбГПУ. 2003. - 300 с.

\section{PHILOSOPHICAL CONCEPTION OF ECOLOGICAL PROBLEMS IN V. I. VERNADSKY'S NOOSPHERE}

Pechenizka S., Ph.D. in Philological Sciences, Associate Professor, International European University, Kyiv, Ukraine

Vysochanska T., Senior Lecturer, International European University, Kyiv, Ukraine

Bondarenko Y., Lecturer, International European University, Kyiv, Ukraine

\section{ФІЛОСОФСЬКЕ ОСМИСЛЕННЯ ЕКОЛОГІЧНИХ ПРОБЛЕМ У НООСФЕРІ В. І. ВЕРНАДСЬКОГО}

Печенізька Світлана Сергіївна, кандидат фрілологічних наук, дочент кафедри суспільних наук та мовної підготовки Міжнародного європейського університету (Київ, Україна),

Височанська Тетяна Миколаївна, старший викладач кафедри суспільних наук та мовної підготовки Міжнародного європейського університету (Київ, Україна),

\section{Бондаренко Юлія Сергіївна,} викладач кафедри суспільних наук та мовної підготовки Міжнародного європейського університету,

(Київ, Україна)

У процесі життєдіяльності людина живе у штучному середовищі, хоча і належить до природи, але й перетворює їі. 3 розвитком міст-мегаполісів, коли переважна більшість людей живе у містах, людина оголошує війну природі за комфортні умови життя. В порівнянні 3 попередніми століттями людська діяльність впливає на природні процеси кардинально. Природа вже не має своїх власних захисних механізмів, тому контроль і відповідальність за збереження і охорону природи має взяти на себе людина. Ще на початку XX ст. відомий український вчений В.І. Вернадський вводить новий термін - ноосфера, який означає всі 
сфери живого і неживого, які охоплюють життєдіяльність людини [2]. Це в свою чергу включає біосферу, певні шари атмосфери і, відповідно, геосфери. Наскільки наша планета пронизана діяльністю людини? Вплив на біосферу визначається тим, що людина вибирає, які рослини вирощувати, яку худобу розводити, які види живих створінь охороняти, а яких знищувати. 3 розвитком техніки і транспорту людина освоїла не тільки наземний й підземний, але й повітряний простір: ми літаємо в небо на літаках і запускаємо ракети, ми спускаємося під землю в метро і глибокі шахти. Вся ця діяльність впливає на природні процеси, змінює середовище, допоки не стане вкрай критичною. Чому людство сьогодні має глобальні екологічні проблеми? Що таке екологія і чому ми маємо вирішувати ці питання? Екологія (грец. oikos - оселя, середовище і logos - слово, вчення) - наука, яка вивчає взаємодію живих організмів і довкілля, відносини між людиною і осередком її проживання [1]. В порівнянні з попередніми століттями, коли людина у своїй праці застосовувала знаряддя переважно природних матеріалів - дерева, згодом заліза, то тепер, на початку XXI ст., переважна більшість продуктів з пластику - матеріалу, який розкладається впродовж тривалого періоду часу і викликає забруднення довкілля, і як наслідок загострення екологічних проблем. Збагнувши загрозу для свого життя, суспільство шукає шляхи подолання і виходу з критичної ситуації. I тут виникає відповідальність кожного перед усіма. ще за часів міфологічного світогляду у людей було розуміння того, що за вчинки однієї людини наслідки може понести інший член спільноти [4]. Так само зараз з екологічною ситуацією - навіть якщо повітря забруднює одна людина, то шкідливі речовини можуть вдихнути інші. І тут постає питання про культуру природокористування, про етичні норми і грамотну організацію процесу створення, розподілу, споживання й утилізації матеріальних благ.

Діяльність людини є творчою і кожен новий крок у науці $є$ креативним. Інтелектуальна діяльність людини - безмежна, і ї̈ роль все більше зростає. Продовженням вчення про Ноосферу - $є$ нооетика. Нооетика - це вчення про етику інтелектуальної діяльності людини, що визначає які закони, правила та критерії розвивати, а які забороняти [3]. Це в свою чергу означає, що людина своїм розумом перетворює все, що ії оточує. Розвиток технологій змінює умови життя і умови праці людей. Стає все менше людей, які проживають у сільській місцевості та задіяні в аграрній сфері, і все більше людей, які проживають у містах і працюють у інформаційній сфері. Це також кардинально змінює середовище проживання людей. Постають нові завдання організації життєвого простору, суспільної комунікації, забезпечення всього необхідного для життєдіяльності. Всі ці дії спрямовані як для задоволення інтересів окремого індивіда, так і для задоволення інтересів суспільства в цілому. Коли ми говоримо про екологію, то тут задіяні не тільки природні процеси, але й процеси суспільства. Як співіснувати з природою і як співіснувати один з одним? Де починається і де закінчується свобода особистості? Як людина може змінювати природу і чи повинна (та в якій мірі) людина підкорюватися природі? Відповіді на такого роду запитання криються у моральних та духовних аспектах ставлення людини до живої і неживої природи. Сьогодні існує 
множинність підходів та різноманітність світоглядних напрямів стосовно цього предмету. В.І. Вернадський стверджував, що людина здатна впоратися з екологічними викликами $\mathrm{i}$ залишити Землю придатною до життя для майбутніх поколінь, тож - все в наших руках, чи не так?

\section{ЛITEPATУPA:}

1. Анісімова, Г.В. (2018) Надзвичайна екологічна ситуація // Велика українська юридична енциклопедія: Екологічне право, 4, 516-519.

2. Гриньова, М. В. (2017) Вчення про ноосферу В. І. Вернадського - основа сучасного природознавства // Імідж сучасного педагога, (3/1(172), 48-54. https://doi.org/10.33272/2522-9729-2017-3/1(172)-48-54

3. Запорожан, В. (2019) Ноосферне вчення Вернадського. Наступний крок нооетика? // Медична освіта https://www.ukrinform.ua/rubric-technology/2656512-noosfernevcenna-vernadskogo-nastupnij-krok-nooetika.html

4. Кравченко, А. П. (2009) Міфологічне та релігійне світовідчуття в осмисленні права // Філософія права, 10, 186-195.

5. Поддубный, И. А. (2013) Наступит ли XXII век? (Перейдет ли биосфера в ноосферу?) Харьков. Очерк 1.94 с. 


\section{ENVIRONMENTAL INDICATORS OF A SEAPORT IN AN INCLUSIVE GROWTH STRATEGY}

Mayorova I.N., Doctor of Economics, Professor, Azov Maritime Institute National University "Odessa Maritime Academy" Mariupol, Ukraine Temerbek A. A., Senior Lecturer, Azov Maritime Institute National University "Odessa Maritime Academy" Mariupol, Ukraine

Nosovckaj O.B., PhD, Associate Professor, Azov Maritime Institute National University "Odessa Maritime Academy" Mariupol, Ukraine

Ryabchuk V., graduate student, Donetsk State University of Management Mariupol, Ukraine Ocheredco E. A., PhD, Associate Professor, Azov Maritime Institute National University "Odessa Maritime Academy" Mariupol, Ukraine

\section{ЕКОЛОГІЧНІ ІНДИКАТОРИ МОРСЬКОГО ПОРТУ В СТРАТЕГІЇ ІНКЛЮЗИВНОГО ЗРОСТАННЯ}

Майорова I.M.,

д.e.н., профресор, Азовський морський інститут НУ «ОМА» Маріуполь, Україна

Темербек А. А., старший викладач, Азовський морський інститут НУ “ОМА» Маріуполь, Україна Носовська О.Б., к.т.н., дочент, Азовський морський інститут НУ «ОМА» Маріуполь, Україна Рябчук В., аспірант, Донецький університет державного управління Очередько О. О., к.е.н., старший викладач, 
Азовський морський інститут НУ «ОМА» Маріуполь, Україна

The international level requirements of the seaports environmental safety are set out in the following documents: 17 Global Sustainable Development Goals for the period up to 2030 [1], which are supported by the United Nations Development Program, ratified by the Cabinet of Ministers of Ukraine, in the ISO 14001 standard [2] and Eco Port PERS [3] ], International Convention for the Safety of Life at Sea SOLAS [4], International Convention for the Prevention of Pollution from Ships MARPOL 73/78 [5], environmental management and audit EMAS [6], Strategy for the development of seaports of Ukraine for the period up to 2038 [7 ].

The modern approach to the organization of environmental management in seaports is formulated in the ESPO report. The Environmental Report is an important tool of the ESPO Ecoports Network together with the Self-Diagnostic Method (SDM) and Port Environmental Assessment System (PERS) [8]. Aggregated data from SDM form the basis of annual environmental reports. Developed by the ports themselves, PERS has established itself as an environmental management standard for the port sector. PERS is an EU research initiative connecting the port network, research universities and industry. More than a fifth of EU ports - EcoPorts members are PERS certified ports.

The proposed indicators of the ecological state of the seaport in the EU ESPO report include the following indicators: A Environmental management indicators, B Environmental monitoring indicators, C Top 10 Environmental priorities, D Green services to shipping [8]. According to PERS requirements, indicators are estimated according to their environmental significance. Significance is determined by interviewing port workers and organizations that operate in the port, shippers and surrounding facilities. This certification demonstrates to a wide range of stakeholders that the seaport is competitive and meets the modern ESPO requirements.

The environmental indices of the seaport meet the requirements of the inclusive sustainable growth concept. [9, p. 15-18]. The concept of inclusive growth is developed on the basis of the "green economy" and differs from the previously used strategies, regulations and principles in complex content and full involvement in government reforms, on the basis of which diversification of national economies takes place. Among the environmental indicators, special attention is paid to: scarcity of water resources, careful use of natural resources, an increase in the share of renewable energy sources; an increase in the dynamics of wooded areas, the quality of the environment and the air basin, namely: the concentration of particulate matter in the atmospheric air, the intensity of carbon dioxide emissions. The solution of these tasks is possible with the creation and use of innovative ideas and products, which provides material for the development of business and scientific research, and the latter, in turn, make it possible to develop the education of the population and increase the number of jobs. Thus, it turns out that solving environmental problems improves the quality of life of people and involves them in additional employment. 
No less interesting is the method of using the Piguvian tax [10, p. 101-108]. The main problems of using the Pigou approach in the case of a seaport is that it is extremely difficult, and sometimes impossible, to correctly measure social costs, since most of them are either psychological or purely individual in nature.

The way out of this situation, apparently, is to determine the specific amount of payments by enterprises, in this case, the seaport, a specific amount for a specific period of time for the use of natural resources and environmental pollution, which is currently being used.

It is impossible to consider separately the environmental situation of the seaport from the environmental situation of the city, the territory where the port is located, and it is impossible not to take into account the environmental principles and approaches that are declared by shippers and shipping companies. The link between the seaport and companies is transport. After all, cargo arrives at the seaport by means of transport. Basically, road and rail transport is used for these purposes. Such an irrational configuration of transport communications by today's standards is explained by the choice of the shortest path and the minimization of transport problems, which was inherited from the socialist way of managing. These principles have been guided in the past when plotting routes along sea coasts, beaches and parks.

The author's approach to determining the environmental indicators of a seaport is as follows: consider transport and transport processes as a link in the seaport environmental system. It is the performance indicators of both internal and external transport of the seaport that determine the ecological state of its environment.

Conclusions. According to the 2008 Strategy for Inclusive Development in European Union Seaports, the ESPO EcoPorts Network indicators are used as environmental indicators together with the Self-Diagnostic Method (SDM) and Port Environmental Assessment System (PERS). Aggregated data from SDM form the basis of annual environmental reports.

It is proposed to approach the assessment of the environmental management of the seaport on the basis of indicators of the saturation of transport processes, both internal and external. The proposed indicators of the ecological state of the seaport can be used in selfdiagnostics of the state of the environment of the port and industrial hub, which is provided for by the System of the ecological state of European ports PERS. Reducing the negative environmental consequences of its activities, the seaport provides its services for transshipment, unloading, storage and processing in the form of achieving a guaranteed quality of the environment, or improving the environmental quality of its services.

\section{REFERENCES}

1. Transforming our world: the 2030 Agenda for Sustainable Development. United Nations. Department of Economic and Social Affairs. Sustainable Development. [Electronic resource] Access: https://sdgs.un.org/2030agenda

2. Introduction to ISO 14001:2015. International Organization for Standardization [Electronic resource]

Access: https://www.iso.org/files/live/sites/isoorg/files/store/en/PUB100371.pdf 
3. Port Environmental Review System (PERS): the only port sector specific environmental management standard. [Electronic resource] Access: https://www.ecoports.com/pers

4. International Convention for the Safety of Life at Sea; SOLAS. IMO. Conventions. [Electronic resource] Access: https://www.imo.org/en/About/Conventions/Pages/InternationalConvention-for-the-Safety-of-Life-at-Sea-(SOLAS),-1974.aspx

5. International Convention for the Prevention of Pollution from Ships (MARPOL). IMO. Conventions.

[Electronic resource]

Access: https://www.imo.org/en/About/Conventions/Pages/International-Convention-for-the-Preventionof-Pollution-from-Ships-(MARPOL).aspx

6. Eco-Management and Audit Scheme. European Commission. [Electronic resource] Access: https://ec.europa.eu/environment/emas/index_en.htm

7. Стратегия развития морских портов Украины на период до 2038 года. https://mtu.gov.ua/files.pdf

8. Отчет по портам EC ESPO Environmental Report - EcoPortsinSights 2020 https://www.espo.be/media/Environmental\%20Report-WEB-FINAL.pdf

9. Kostetska, K., Khumarova, N., Umanska, Y., Shmygol, N., \& Koval, V. (2020). Institutional qualities of inclusive environmental management in sustainable economic development. Management Systems in Production Engineering, 28 (2), 15-22. https://doi.org/10.2478/mspe2020-0003

10. Mikhno, I., Koval, V., Shvets, G., Garmatiuk, O., \& Tamošiūnienė, R. (2021). Green Economy in Sustainable Development and Improvement of Resource Efficiency. Central European Business Review, 10(1), 99-113. https://doi.org/10.18267/j.cebr.252

\title{
ENTREPRENEURIAL ACTIVITY IN THE CONDITIONS OF IMPLEMENTATION OF THE PUBLIC- PRIVATE PARTNERSHIP
}

\author{
Gechbaia B., \\ Head of research center of BNTU, Professor, Georgia
}

Koval V.,

Odessa Institute of Trade and Economics of Kyiv National University of Trade and Economics, Ukraine

In the conditions of post-industrial modernization of the world economy, the transition of modern civilization towards sustainable development, entrepreneurship is becoming an integral link in the structure of the social reproduction process, without which it is impossible to ensure successful socio-economic development and an increase in production efficiency. 
The current economic regulation of the development of the entrepreneurial sector in the context of its adaptation to the imperatives of the expanded-reproduction mode of functioning of the economy is the most important tool for achieving the stated targets, such as: ensuring sustainable development; equalizing the levels of socio-economic development, improving the quality of life of the country's population and improving the social climate in society, and the like.

The construction of an effective mechanism for the interaction of power and business structures within the modern economic system requires significant costs, which can ensure the evolutionary nature of building a socio-institutional structure adequate to market conditions. Based on the foregoing, we note that the research topic is relevant and necessitates a comprehensive study of the relations that develop during the period of social transformation between government and business entities [1-5]. The implementation of this direction requires a combination of the achievements of various fields of economic knowledge with practical domestic and foreign experience in reforming and, in particular, public administration [6-10].

The lack of a mechanism for systemic regulation of entrepreneurship development requires generalization of theoretical and empirical experience in order to form adaptive measures for the development of the domestic economy in the context of changes in the organizational forms of interaction between government bodies and private business entities and in combination of state and market mechanisms for regulating the business sector [11-15].

Therefore, the purpose of this article is to substantiate adaptive measures of state regulation of entrepreneurial activity in the context of public-private partnership.

Modern phenomena that take place in domestic economic practice - monopolization, low income and differentiation of the bulk of the population - are a form of manifestation of the imbalance in the system of economic interests of modern Ukrainian society. Taking into account that these interests are quite contradictory, in our opinion, it is necessary to find common for all economic entities [16-18].

Thus, if entrepreneurial structures interact in unequal socio-economic and legal conditions, then this leads to the subordination of the economic interest of one subject of the economic interest of another subject. In such a situation, the desire to achieve high economic results weakens, which ultimately leads to a slowdown in the development of entrepreneurial structures.

With two-way communication and mutual benefit of economic relations of business entities, the most favorable conditions are created for the entrepreneurial activity of each of them.

The system of public-private partnership (PPP) will help solve the problem of harmonizing the interests of all stakeholders and, accordingly, solving the most pressing problems.

However, the implementation of large-scale modernization projects in the sectors of Ukraine requires significant investment resources, a powerful source of which can be private business. 
At the same time, in the conditions of post-crisis development, business interest in state support is growing, which will reduce the risks of private investments, increase the reliability of investment projects for credit institutions.

Ensuring a balance of interests of all structural elements of the economic system of the corresponding level is the goal of forming an adaptive mechanism of interaction.

Adaptive measures of interaction between government and business structures are aimed at solving the following goals and objectives:

- maintaining a balance of private and public interests with the unity of the goals of both government bodies and business structures;

- the activity of the authorities in ensuring the availability of infrastructure services, the creation of a favorable business environment in the country and regions;

- business activity of entrepreneurial structures, including innovation, production, commercial, investment activity.

As part of building adaptive interaction, it is necessary to conduct the following activities:

1. Optimization of the institutional environment, including the reduction of administrative barriers to the development of entrepreneurial activity.

2. Systematization and improvement of legislation governing the activities of public and other non-profit organizations, their interaction with executive authorities.

3. Reforming the system of technical regulation, which today remains one of the main barriers to innovation development as well.

Partnership relations between the state and private business are organically included in the sphere of production of public goods on the basis of a larger-scale use of the system of contractual relations, significantly supplements, and sometimes even replaces, direct power mechanisms of organization and management in the economy.

The processes of public-private partnership are often very complex, it also leads to increased costs, as well as to the fact that only the largest enterprises remain among the bidders for contracts. Simplification of the rules promotes competition, which, in turn, expands the range of bidders for a contract, from which government agencies can choose their best partners.

For the successful development of public-private partnership in Ukraine, it is necessary to apply a systematic approach, namely:

- to determine a single state body responsible for the implementation of the public-private partnership policy, endowed with appropriate powers;

- to develop a single program document - a phased concept, strategy and a clear action plan for the short and long term, providing for the coordinated and balanced use of the most relevant PPP tools, with its linking to the country's long-term development strategy;

- to develop proposals for improving legislation, in terms of state support for private initiative (investment legislation), delineation of powers and responsibilities of state bodies, legislation on the securities market, etc .; 
- to conduct constant systemic monitoring and analysis of the application of elements of public-private partnership in order to search for opportunities to correct their further development.

Only such a comprehensive, systematic and justified introduction and implementation of a public-private partnership policy, in accordance with international experience, can have a positive effect on the development of the economy and society as a whole. The implementation of this large-scale socio-political and economic transformation of economic relations largely depends on how complete, consistent, high-quality the legislative framework, institutional environment, economic and organizational study of all aspects of the problem of the formation of public-private partnership in Ukraine will be.

\section{References}

1. Baklanova, O., Petrova, M., Koval, V. (2020). Institutional Transmission in Economic Development. Ikonomicheski Izsledvania, 29(1), 68-91.

2. Petrova, M., Koval, V., Tepavicharova, M., Zerkal, A., Radchenko, A., \& Bondarchuk, N. (2020). The interaction between the human resources motivation and the commitment to the organization. Journal of Security and Sustainability Issues, 9(3), 897-907.

3. Koval, V., Slobodianiuk, O., \& Yankovyi, V. (2018). Production forecasting and evaluation of investments using Allen two-factor production function. Baltic Journal of Economic Studies, 4(1), 219-226. doi:10.30525/2256-0742/2018-4-1-219-226

4. Bublyk, M., Koval, V., \& Redkva, O. (2017). Analysis impact of the structural competition preconditions for ensuring economic security of the machine building complex. Marketing and Management of Innovations, (4), 229-240. doi:10.21272/mmi.2017.4-20

5. Koval, V., Prymush, Y., \& Popova, V. (2017). The influence of the enterprise life cycle on the efficiency of investment. Baltic Journal of Economic Studies, 3(5), 183-187. doi:10.30525/22560742/2017-3-5-183-187

6. Nazarova, K., Hordopolov, V., Kopotiienko, T., Miniailo, V., Koval, V., \& Diachenko, Y. (2019). Audit in the state economic security system. Management Theory and Studies for Rural Business and Infrastructure Development, 41(3), 419-430.

7. Kvach, Y., Piatka, N., \& Koval, V. (2020). Management of sustainable entrepreneurship adaptation to tax changes in environmental investment. Baltic Journal of Economic Studies, 6(5), 96-105. https://doi.org/10.30525/2256-0742/2020-6-5-96-105

8. Mikhno, I., Koval, V., Korenyuk, P., Smutchak, Z., \& Bozhanova, V. (2021). Modeling corporate games to increase the ecological value of entrepreneurship and innovative business. E3S Web of Conferences, 255, 01027.

9. Popova, O., Koval, V., Antonova, L., \& Orel, A. (2019). Corporate social responsibility of agricultural enterprises according to their economic status. Management Theory and Studies for Rural Business and Infrastructure Development, 41(2), 277-289. https://doi.org/10.15544/mts.2019.23 
10. Shmygol, N., Schiavone, F., Trokhymets, O., Pawliszczy, D., Koval, V., Zavgorodniy, R., Vorfolomeiev A. (2020). Model for assessing and implementing resource-efficient strategy of industry. CEUR Workshop Proceedings, 2713, 277-294.

11. Koval, V., Mikhno, I., Trokhymets, O., Kustrich, L., Vdovenko, N. (2020). Modeling the interaction between environment and the economy considering the impact on ecosystem. E3S Web Conferences, 166, 13002. https://doi.org/10.1051/e3sconf/202016613002

12. Yankovyi, O., Goncharov, Yu., Koval, V., \& Lositska, T. (2019). Optimization of the capitallabor ratio on the basis of production functions in the economic model of production. Naukovyi Visnyk Natsionalnoho Hirnychoho Universytetu, 4, 134-140.

13. Tamosiuniene, R., Demianchuk, M., Koval, V. (2019). State Regulation of Bankruptcy Relations in the National Economy. Economics. Ecology. Socium, 3 (4), 19-27.

14. Gechbaia, B., Tchilaia, N., Goletiani, K., \& Muskudiani, Z. (2020). Ways and characteristics of employee motivation in modern conditions. Social and Labour Relations: Theory and Practice, 10(1), 25-32. https://doi.org/10.21511/sirtp.10(1).2020.05

15. Mushkudiani, Z., Gechbaia, B., Gigauri, I., \& Gulua, E. (2020). Global, economic and technological trends in human resource management development. ACCESS: Access to Science, Business, Innovation in Digital Economy, 1(1), 53-60. https://doi.org/10.46656/access.2020.1.1(4)

16. Zurab Mushkudiani, Badri Gechbaia. Facing the Global Competitiveness Challenge and Quality of Business Freedom in Georgia. (2019). European Journal of Economic Studies, 8(2). https://doi.org/10.13187/es.2019.2.131

17. Prokopenko, O.V., \& Shkola, V.Y. (2012). Controlling of the ecological and economic enterprise security on the bases of ecomarketing. Marketing and Management of Innovation, 4, pp. 337-346.

18. Prokopenko, O.V., Shkola, V.Yu., \& Omelyanenko, V.A. (2013). Analysis of the use of international leasing in terms of improving the effectiveness of technology transfer by the example of agroindustrial complex. Marketing and Management of Innovations, 3, pp. 185-199. 


\section{THE IMPACT OF EQUIPMENT UPGRADES IN THE REPAIR AND MAINTENANCE OF WATER TRANSPORT ON THE EXAMPLE OF "ILYICHEVSK SHIPREPAIR YARD" PUBLIC JOINT-STOCK COMPANY}

Holovin O., graduate student, Odessa National Maritime University Odesa, Ukraine

\section{ВПЛИВ ОНОВЛЕННЯ ОБЛАДНАННЯ У РЕМОНТІ ТА ОБСЛУГОВУВАННІ ВОДНОГО ТРАНСПОРТУ} НА ПРИКЛАДІ ПУБЛІЧНОГО АКЦІОНЕРНОГО ТОВАРИСТВА "ІЛЛІЧІВСЬКИЙ СУДНОРЕМОНТНИЙ ЗАВОД (ПАТ) " ІСРЗ "

О.О. Головін, аспірант,

Одеський національний морський університет Одеса, Україна

Вибір виду транспорту при перевезенні вантажів відіграває важливу роль на користь економіки країни. Він підвищує конкурентоспроможність за рахунок ефективності контактування на районному, обласному та державному рівнях. Судноплавство займає суттєве місце в морському потенціалі країни. Bсе це дає можливість створювати торгові контракти з іншими країнами. Істотні зміни в перебігу останніх років значно скоригували розвиток транспортної системи, як наслідок, попит на ремонт морського транспорту знизився.

Всесвітня пандемія COVID-19 внесла корективи у роботу судноремонтних заводів та портів. Річний графік ремонту судів довелося повністю змінити через рішення міжнародної організації судноплавства (IMO, International Maritime Organization), яка продовжила на три місяці сертифікати технічного стану всіх цивільних суден. Підписані контракти відсунулися на більш пізній термін. У зв'язку з цим, судноремонтні підприємства по всьому світу переглядають свої графіки роботи підлаштовуючись під нові вимоги міжнародной організації судноплавства (IMO) [1].

СУДноремонтному заводу ПрАТ «ІСРЗ»ПУБЛІЧНЕ АКЦІОНЕРНЕ ТОВАРИСТВО «ІЛЛІЧІВСЬКИЙ СУДНОРЕМОНТНИЙ ЗАВОД» В Чорноморську успішно освоєна така затребувана зараз робота, як модернізація баластної системи. Встановлюються системи ALFA LAVAL i ERMA FIRST. Завдяки цьому вже більше трех років поспіль на «ICP3» регулярно приходять теплоходи польської державної судноплавної компанії Polsteam (Polish Steamship Company) - польська державна судноплавна компанія, заснована в 1951 році - один з найбільших судновласників і перевезе і навалювальних 
вантажів. PZM, що є власником близько 3\% балкерного флоту світу. Це близько 80 теплоходів класу Handysize, Panamax, Afromax. [2]. Якщо впаде кількість замовлень на ремонт, тоді судноремонтні заводи і регіон залишаться без фінансування. Буде ефективність з'єднати ці дії з замовником і виробництвом таким чином, щоб економічно було вигідно двом сторінам. Як показує практика в Україні судно стає на ремонт, а на зворотному ходу бере вантаж в Одескому регіоні або Миколаєві. Сприйняття цього, наскільки люди і організації розуміють методи і взаємодіють з технологічними рекомендаціями, здатність внести замовника в фокус інтегрованого комплексу.

В ході ремонту суден здійснюється їх переклад з класу місцевого регістра країни реєстрації судна в DNV (DNV GL-Det Norske Veritas i Germanischer Lloyd) 3 підвищеними вимогами. DNV входить в десятку кращих світових сюрвеєрів і переклад судів в його регістр $\epsilon$ вимогою страхових компаній. Більш високий регістр - це підвищені вимоги до технології ремонту, охорони праці та т.д. [2]. Замовнику показують ефективність вибору, прийняття і відчуття угоди сучасних методів.

Соціальні та громадські науки показують своєсприяння ефективністі такими методами планірованя данной синтетичної сфери і її транспортну програму.

Вітчизняні (СРЗ) прищепили європейський підхід до всього - до питання строковє дисципліни, виконання робіт, їх технічного оформлення і супроводу - креслень, розрахунків тощо. Це аргументи для замовників подолати більшу відстань і зайти на судноремонтний завод. Така складна і трудомістка робота дає можливість працевлаштувати кваліфікованих фахівців. Переслідуючи мету досягти звершення, індустрія, наука і техніка так само політичні діячі повинні працювати спільно з аналогічним обивателем. Україна має в своєму розпорядженні сучасні експерименти і також володіє знаннями, що визначають нас з вами в передовій регіон транспортних технологій. Використовуючи виробничу політику і в більшому значенні, підприємствам необхідно застосовувати комерційний потенціал, для того, щоб повністю застосувати дані ресурси, організація транспортної лінії, підготовленої до наступаючої нової технології. Наприклад, на заводі «ІСРЗ» з'явилася плазмова різка металу. Нові машини та технології дозволили скоротити час ремонту на 10\%. Досить серйозні зміни зазнав парк зварювального обладнання - з'явилися зварювальні трактори, векторні напівавтомати, лабораторія зварювання та зварювальне бюро. Все це дозволило істотно розширити ареол можливостей виконання зварювальних робіт. Виконують роботи по зварювання алюмінію, сплавів кольорових металів, ремонт гвинтів на плавці, зварювання чугуніну, спецсталі [2]. 
Замовник та обслуговуючі підприємства на утримання ремонтного штату складають витрати, пов'язані з виробництвом продукції, можуть бути згруповані за такими статтями калькуляції: сировина і матеріали; покупні комплектуючі вироби, напівфабрикати, роботи і послуги виробничого характеру сторонніх підприємств і організацій; паливо і енергія на технологічні цілі; зменшення або збільшення витрат (віднімаються); основна зарплата виробничих робітників; додаткова зарплата виробничих робітників; відрахування на соцстрахування; витрати на утримання та експлуатацію обладнання; загальновиробничі витрати; втрати внаслідок технічно неминучого браку; супутня продукція (віднімається); інші виробничі витрати. Залежно від особливостей технології та організації виробництва, а також питомої ваги в собівартості продукції окремих видів витрат підприємства можуть об'єднувати деякі наведені статті калькуляції в одну або, навпаки, виділяти з однієї типової статті кілька статей калькуляції. Встановлення переліку і складу статей калькулювання виробничої собівартості продукції віднесено до компетенції підприємства і має бути регламентоване його обліковою політикою [3].

Таким чином, ризики, що виникають, при реалізації проектів в судноремонтних заводах та морських портах, можна умовно розділити на сім груп: ризики держави; ризики інвесторів; ризики органів місцевої влади; ризики трудового колективу порту /заводу; ризики контролюючих органів; ризики громадян; ризики портового бізнесу. Усі перераховані види ризиків призведуть до виникненню ризику збитку [4 с.137]. У цьому варіанті розвитку подій скорочення часу робіт на судноремонтному заводі призводить до застосування нових методів та технологій. Подібні впровадження вплинуть на збільшення й старіння обладнання, не будуть відповідати науково-технічним можливостям в сфері електроенергетики, цифровізації та автоматизації процесів. Але сучасні технології повністю розкриють свій потенціал. Рекомендуючи нові технології виробництва на приклад DIJ (Do Its Job) в інтересах реалізації наявний поточних потреб сучасних рішень. Але вони аналогічно можуть доставити труднощі. Для того, щоб реалізувати повний пакет методів й технологій для ремонтів та переоснащення суден [5 с. 46]. Необхідно досягти реальних видозмін, тобто, розглядати транспорт за транспорт за образом техносистеми: піддавати розгляду її в дусі цілісності.

Висновки. Важливе значення у аутсорсингу судноремонтних заводів має зниження економічної складової в ремонті і обслуговуванні обладнання, важливою складовою $\epsilon$ витрати на заробітну плату і покупку і обслуговування дорогого устаткування. Фактори які впливають на процес застосування розділимо на групи: 
1. Наведені результати доводять той факт, що дотримання умов перекладу з класу державного реєстру країни в більш високий DNV регістр також можливий в ході ремонту суден.

2. У нинішній відрізок часу, діяльність на ринку судноремонтної сфери України містить багато викликів іпретензій, і лише їх дозволу організовує здатності переваги сучасних горизонтів для підйому, розробка спеціальних і нових трудових місць і об'єднаного прогресу економіки країни та її регіонів.

3. У комплексі застосування нових технологій, методів виробництва і потужностей у ремонті модернізації усіх судів застосовувати сучасні технології ремонту на аутсорсинг. Економічно буде виправдано замовникам запрошувати висококваліфікованих фахівців, а не утримувати свій штат фахівців і дороге устаткування.

Таким чином застосування аутсорсинга у виробничих підприємствах підвищить економіку підприємства і збереже фінансові кошти замовника для розвитку свого бізнесу.

\section{Список використаних джерел:}

1. https://dumskaya.net/news/iz-za-resheniya-mezhdunarodnoy-organizatcii-sudo-131913/

2. https://sudohodstvo.org/sudoremontnyj-zavod-chao-isrz/

3. https://i.factor.ua/journals/nk/2014/november/issue-22/article-3427.html

4. Шахов А.В. Пітерская В.М. Боцанюк В.Н. Міжнародна наукова- практічна конференція «Математичне моделювання процесів в економіці та управлінні проектами и програмами » (ММП-2020), Коблево , 14-18 вересня 2020 р. Праці - Харків : ХНУРЕ, 2020.-144 с. 136-138 с.

5. Головін О.О. Міжнародна наукова-практична конференція «Математичне моделювання процесів в економіці та управлінні ін про єктами и програмами» (ММП-2020), Коблево, 14-18 вересня 2020 р. Праці - Харків: ХНУРЕ, 2020.-144 с. 46-48 с. 


\section{TRENDS OF INDUSTRIAL ENTERPRISES DEVELOPMENT IN THE CONTEXT OF DIGITALIZATION}

Prokopenko M.,

Kyiv National University of Technology and Design, Ukraine

Kochubei O., Kyiv National University of Technology and Design, Ukraine; Teadmus OÜ, Estonia

Digitalization has influenced the development of industrial enterprises from the late $X X$ early XXI century. But earlier, if it was easier for small companies to introduce new technologies, recently, an increasing number of medium and large enterprises are using digital technologies and switching to automation.

In current conditions, two main trends can be distinguished: strengthening globalization processes and an innovative economic development priority. In the context of globalization of socio-economic processes, engaging in effective entrepreneurial activity becomes extremely difficult. An entrepreneur is required not only practical skills and knowledge of economics and jurisprudence but also possession of unique methods that allow a systematic approach to the analysis of a problem situation, be able to predict the consequences of certain actions, find innovative entrepreneurial solutions, especially in the conditions of modern competition in the Ukrainian and world market.

Therefore, especially in the field of industry, innovative scientific developments are of particular value, which can be applied at an enterprise to reduce the cost of production, reduce resource costs, and automate those solutions where it is possible without manual human labor.

Also, the latest trend is the transfer of the maximum amount of possible work online, maintaining databases, accounting for products, etc. online, using cloud technologies. It allows you to increase productivity and efficiency, connect additional tools to analyze the situation, identify anomalies in the production cycle, and track the results remotely. It makes it possible to hold prompt meetings and boards of directors and make quick decisions.

In addition, the ability to pay for services and products online also has an impact on the development of industrial enterprises in Ukraine. It makes it possible to timely pay for raw materials, ordering them from different countries of the world, receiving payments from customers, and almost automatically generating accounting reports, monitoring the company's monetary balance, and paying taxes online. It reduces corruption and allows businesses to conduct business transparently, which affects consumer loyalty and saves time on converting cash, exchanging currencies for international payments, and creating reports manually.

Thus, in the context of digitalization, there are tendencies towards the automation of production, and the transfer of possible work and payments online, which makes it possible to reduce the cost of the production process, save employees' time, and also make the necessary decisions on the restructuring of the company faster. 


\section{REFERENCES}

1. Babkin A.V., Aletdinova A.S. Digital transformation of the economy and industry: problems and prospects: monograph / Ed. Dr. econ. Sciences, prof. A.V. Babkin. SPb: Publishing house of Polytechnic. University, 2017, 807 p. (in Russian).

2. Vertakova Yu.V., Tolstykh T.O., Shkarupeta E.V., Dmitrieva E.V. Transformation of management systems under the influence of digitalization of the economy: monograph. Kursk: Federal State Budgetary Educational Institution of Higher Education "South-Western State University", 2017, 147 p. (in Russian). 
International Conference on Sustainable Transport System and Maritime Logistics

Sustainable Transport System and Maritime Logistics

Proceedings of the $3^{\text {rd }}$ International Scientific Conference

Batumi, Georgia

June 24, 2021

Copying of content is not permitted except for personal and internal use, to the extent permitted by national copyright law, or under the terms of a CC BY-NC 4.0 License.

Batumi Navigation Teaching University № 38 Tamer Mefe ave., Makhinjauri; Batumi; Georgia E-mail: b.gechbaia@bntu.edu.ge, Website: www.bntu.edu.ge

$+$

$+$

$+$

\&

+

+

$+$

+

+

$+$

$+$

+

+

+

+

+

+

$+$

+

+

平

$+$

$+$

$+$

+

+

+

平

$+$

+

+

乎

$+$

+

$+$

\&

옹

胥

$+$

+

+

+

$+$

东 